Lawrence Livermore National Laboratory

University of California

Livermore, California 94551

\title{
Nitrate and Perchlorate Removal from Groundwater by Ion Exchange
}

Pilot Testing and Cost Analysis

Authors

Stephany Burge*

Rolf Halden

\section{September 8, 1999}




\section{DISCLAIMER}

This document was prepared as an account of work sponsored by an agency of the United States Government. Neither the United States Government nor the University of California nor any of their employees, makes any warranty, express or implied, or assumes any legal liability or responsibility for the accuracy, completeness, or usefulness of any information, apparatus, product, or process disclosed, or represents that its use would not infringe privately owned rights. Reference herein to any specific commercial product, process, or service by trade name, trademark, manufacturer, or otherwise, does not necessarily constitute or imply its endorsement, recommendation, or favoring by the United States Government or the University of California. The views and opinions of authors expressed herein do not necessarily state or reflect those of the United States Government or the University of California, and shall not be used for advertising or product endorsement purposes.

This report has been reproduced directly from the best available copy.

Available to DOE and DOE contractors from the Office of Scientific and Technical Information

P.O. Box 62, Oak Ridge, TN 37831

Prices available from (423) 576-8401

Available to the public from the National Technical Information Service

U.S. Department of Commerce 5285 Port Royal Rd., Springfield, VA 22161 


\title{
Nitrate and Perchlorate Removal from Groundwater by Ion Exchange
}

Pilot Testing and Cost Analysis

Authors

Stephany Burge*

Rolf Halden

\section{September 8, 1999}

\author{
*University of Idaho Moscow, Idaho
}

\section{Environmental Protection Department}



TABLE OF CONTENTS

Summary _ 2

Introduction

Theory__ 4

Ion Exchange Test Unit _ 5

Ion Exchange Pilot Testing __ 7

Results and Discussion__ 7

Conclusion__ 12

Acknowledgements 13

References__ 13

Appendix A - Pilot Testing Procedure

Appendix B - Data

Appendix C - Hach Test Kit Results

Appendix D - Perchlorate Tests and Predictions

Appendix E - Cost Analysis

Appendix F - Sample Calculations

Appendix G - Optimized Regeneration Cycle Times 


\section{SUMMARY}

This study was conducted to evaluate the performance of a small scale ion exchange unit (Krudico, Inc of Auborn, IA) for removal of nitrate and perchlorate from groundwater at Lawrence Livermore National Laboratory's Site 300. The unit was able to treat 3,600 gallons of Site 300 groundwater, at an average influent concentration of $100 \mathrm{mg} / \mathrm{L} \mathrm{NO}_{3}{ }^{-}$before breakthrough occurred. The unit contained $2.5 \mathrm{ft}^{3}$ of Sybron SR-7 resin. Seventy gallons of regeneration waste were generated (water treated to waste ratio of 51:1). The effluent concentration was about $20 \mathrm{mg} / \mathrm{L} \mathrm{NO}_{3}^{-}$, which is equivalent to a treatment efficiency of at least $80 \%$.

There are several options for implementing this technology at Site 300. A target well, in the 817 area, has been selected. It has a 3 to 4 gpm flow rate, and concentrations of $90 \mathrm{mg} / \mathrm{L} \mathrm{NO}_{3}{ }^{-}$and 40 $\mu \mathrm{g} / \mathrm{L}$ perchlorate. The different treatment options include ion exchange treatment of nitrate only, nitrate and perchlorate, or perchlorate only.

\section{Option 1}

For the treatment of nitrate only, this unit will be able to treat 3,700 gallons of water before regeneration is required. If both columns of the ion exchange unit are used, 7,400 gallons could be treated before the columns will need to be regenerated (producing 140 gallons of waste, per cycle or every 1.5 days). The effluent nitrate concentration is expected to be about $17 \mathrm{mg} / \mathrm{L}$. Annual operation and maintenance costs are estimated to be $\$ 0.14$ per gallon of water treated.

\section{Option 2}

If only perchlorate is to be removed with ion exchange at the 817 area, a smaller unit should be considered. A 55 gallon canister filled with ion exchange resin should be able to reduce perchlorate concentrations in the groundwater from $40 \mu \mathrm{g} / \mathrm{L}$ to non-detect levels for three years before the resin would need to be replaced. The contaminant-laden resin would be disposed of as hazardous waste. It is not practical to regenerate the resin because of the extreme difficulty of removing perchlorate from the resin. Due to the selectivity of the ion exchange resin, it will also be possible to selectively remove perchlorate from nitrate-contaminated water. Annual operation and maintenance costs are estimated to be $\$ 0.02$ per gallon of water treated.

\section{Option 3}

Another alternative is to treat both perchlorate and nitrate. A three column unit would be built. The first column would capture perchlorate and the resin would be replaced rather than regenerated. The second and third column would be operated as under Option 1 to treat nitrate. Annual operation and maintenance costs are estimated to be $\$ 0.14$ per gallon of water treated.

\section{INTRODUCTION}

Site 300 is on the National Priorities List as a Superfund Site because its groundwater is contaminated with numerous compounds including volatile organic chemicals (VOCs), nitrate, and perchlorate (Figure 1). This paper focuses only on the removal of the latter two compounds via an ion exchange process. Ion exchange has been extensively studied for the removal of nitrate from 
drinking water sources. ${ }^{1}$ Other studies have suggested that some ion exchange resins can be used to remove perchlorate. ${ }^{2}$

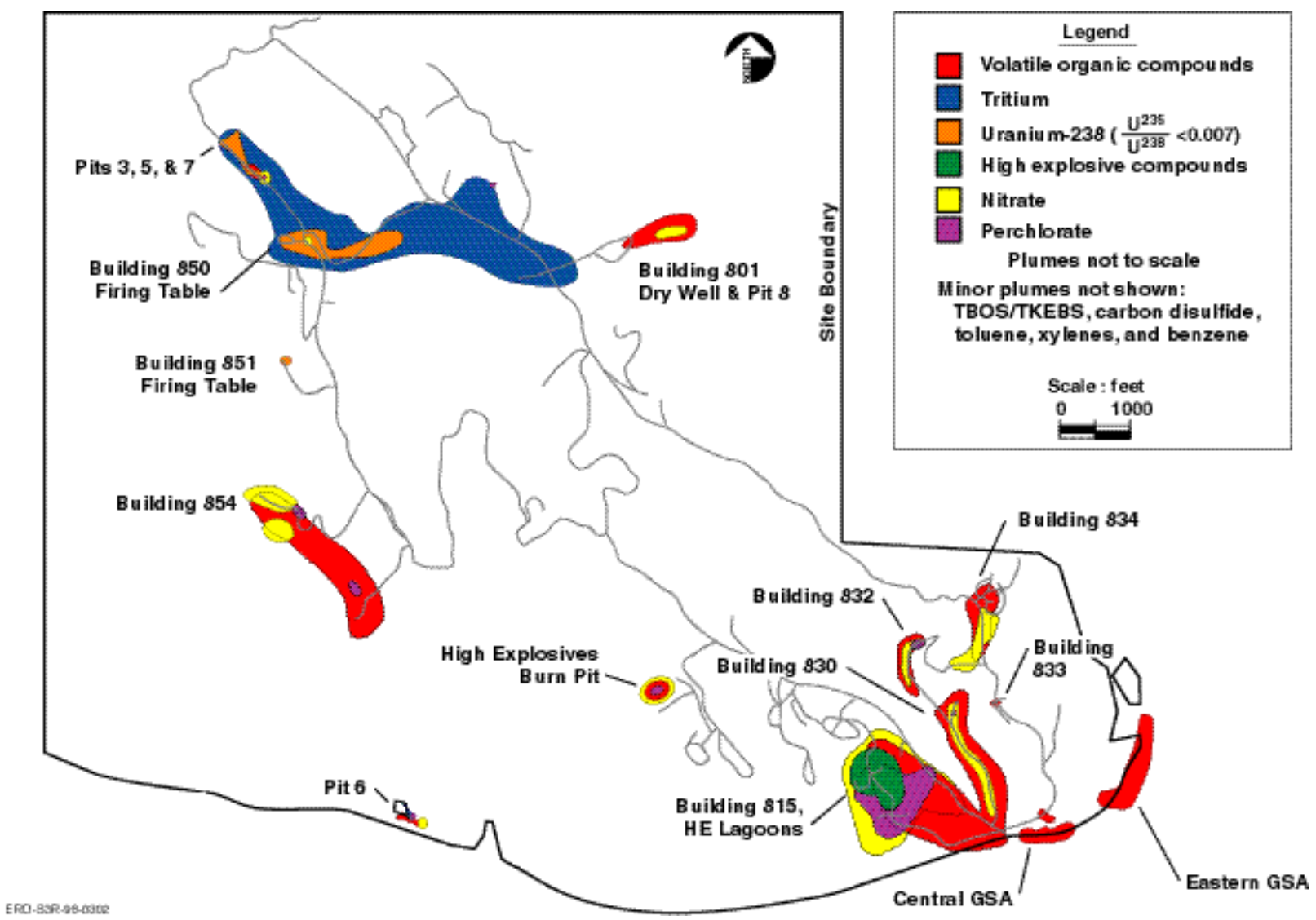

Figure 1: Extent of groundwater contamination at Site 300.

A test scenario has been developed for later comparison of the various remedial technologies. This scenario represents the data observed at the target well W-817-03, which is located in the 817 area of Site 300 . The physical parameters associated with the well are a 3 to 4 gpm flow rate, and concentrations of $90 \mathrm{mg} / \mathrm{L} \mathrm{NO}_{3}{ }^{-}$and $40 \mu \mathrm{g} / \mathrm{L}$ perchlorate.

The discharge limit for either compound has not yet been set (Table 1). For perchlorate, the discharge limit may be set at background levels, which are equivalent to the current detection limit of less then $4 \mu \mathrm{g} / \mathrm{L}$. Nitrate discharge limits may either be the maximum contaminant level (MCL), background level, or the detection limit (less then $0.5 \mathrm{mg} / \mathrm{L} \mathrm{NO}_{3}{ }^{-}$). Contaminant background levels vary across the site and have not been determined for the 817 target area. Overall, it has been estimated that discharge limits will be set between 20 and $45 \mathrm{mg} / \mathrm{L} \mathrm{NO}_{3}{ }^{-}$at Site 300 . 
Table 1: Summary of the concentrations, background levels and regulatory limits for nitrate and perchlorate in the 817 target area

\begin{tabular}{|c|c|c|c|c|}
\hline $\begin{array}{l}\text { Contaminant } \\
\text { of Concern }\end{array}$ & $\begin{array}{c}\text { MCL or } \\
\text { Action level }\end{array}$ & $\begin{array}{c}\text { Concentration at } \\
\text { W-817-03 }\end{array}$ & $\begin{array}{c}\text { Background } \\
\text { Levels }\end{array}$ & $\begin{array}{c}\text { Estimated } \\
\text { Discharge Limits }\end{array}$ \\
\hline Nitrate & $\begin{array}{l}45 \mathrm{mg} / \mathrm{L} \\
\left(\text { as } \mathrm{NO}_{3}^{-}\right)\end{array}$ & $90 \mathrm{mg} / \mathrm{L}$ & Undetermined & $\begin{array}{l}\text { Background to } \\
\text { MCL }\end{array}$ \\
\hline Perchlorate & $18 \mu \mathrm{g} / \mathrm{L}^{\mathrm{a}}$ & $40 \mu \mathrm{g} / \mathrm{L}$ & Non-detect ${ }^{b}$ & Non-detect ${ }^{\mathrm{c}}$ \\
\hline
\end{tabular}

\section{THEORY}

Ion exchange resins exploit functional groups that are initially bonded to chloride ions. The resin used in this experiment consists of a styrene-divinylbenzene copolymer attached to a quaternary amine functional group.

When contaminated water flows over the resin beads, the chloride ion is exchanged for a nitrate or perchlorate ion because of its relatively higher affinity for the quaternary amine group (Figure 2). The chloride ion flows out with the effluent stream, while the exchanged ion remains bonded to the functional group. When all of the resin's functional groups have been bonded to contaminant anions, the resin is saturated. The resin is then regenerated with a saturated sodium chloride brine solution. Due to the regeneration solution's high concentration of chloride ions in relation to the contaminant ions on the resin, the chloride will displace the contaminant from the resin's functional group. The resin is then rinsed with the process water and returned to service. The regeneration wastewater is collected and disposed of as industrial wastewater.
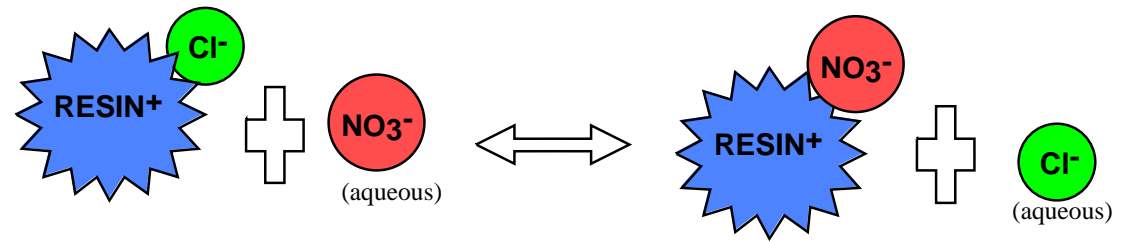

Figure 2: Ion exchange reaction mechanism for anion specific resin.

The resin also attracts similar anions including carbonate and sulfate. Nitrate specific resin has been proven to have affinity for the following ions in decreasing order. ${ }^{3}$

$$
\mathrm{NO}_{3}^{-}>\mathrm{SO}_{4}^{-2}>\mathrm{Cl}^{-}>\mathrm{HCO}_{3}^{-} \quad \text { (Equation 1) }
$$

It has been suggested that perchlorate has a higher affinity for the resin than that of nitrate. ${ }^{4}$ Depending on the concentrations of alternate ions (mainly sulfate), premature leakage of nitrate and possibly perchlorate can occur. Leakage occurs when some of the contaminant ions appear in the effluent water beginning immediately after startup and continuing until breakthrough occurs. 


\section{ION EXCHANGE TEST UNIT}

Several different resins were evaluated in a previous in-house study, including one general anion resin and three nitrate specific resins. ${ }^{5}$ Based on this study, a test unit containing the nitrate specific Sybron SR-7 resin was selected for pilot testing (Figure 3). Specifications for the test unit are summarized in Table 2.

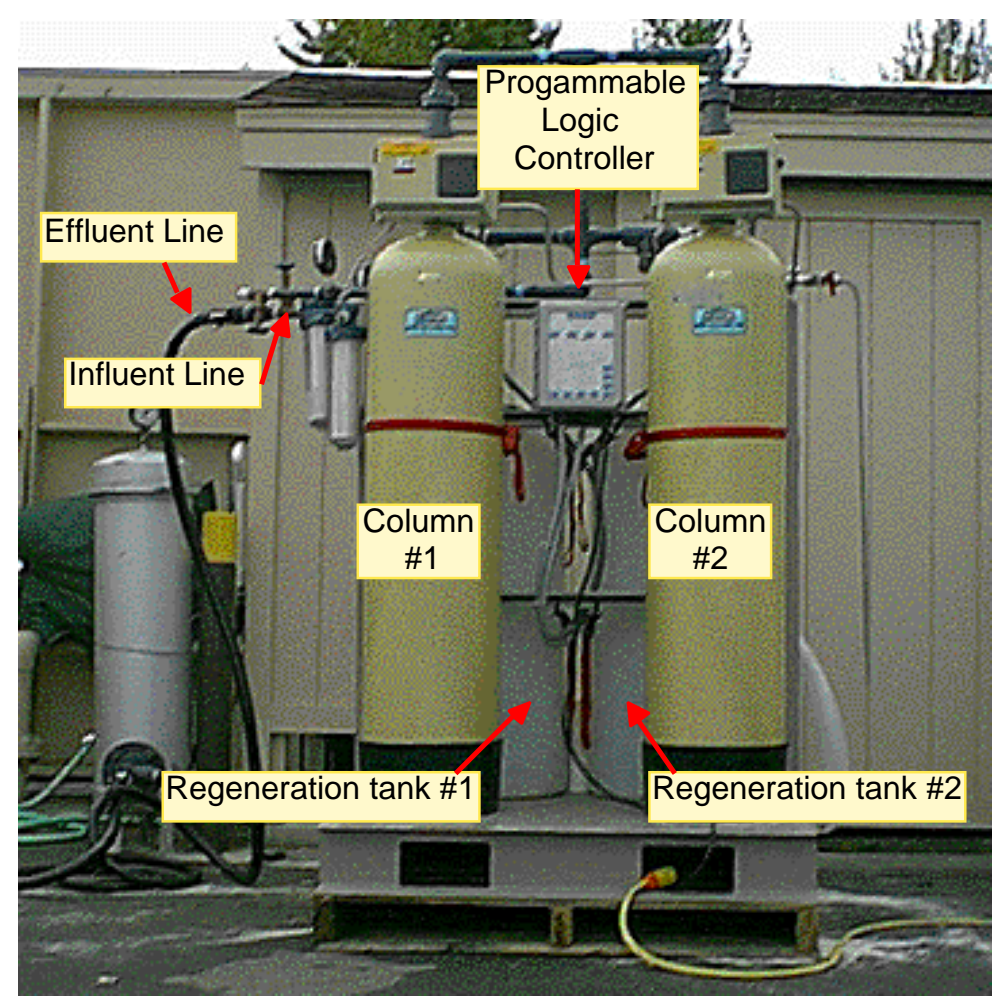

Figure 3: Krudico's alternating dual tank nitrate removal ion exchange unit, which was used in this pilot study.

Table 2: Krudico's ion exchange unit's operational parameters and associated costs.

\begin{tabular}{lcccc}
\hline & $\begin{array}{c}\text { Operating } \\
\text { Flow }\end{array}$ & $\begin{array}{c}\text { Maximum } \\
\text { Flow }\end{array}$ & $\begin{array}{c}\text { Minimum } \\
\text { Flow }\end{array}$ & $\begin{array}{c}\text { Resin } \\
\text { Quantity }\end{array}$ \\
\hline One Column Mode & $7.5 \mathrm{gpm}$ & $12.5 \mathrm{gpm}$ & $4 \mathrm{gpm}$ & $2.5 \mathrm{ft}^{3}$ \\
Two Column Mode & $15 \mathrm{gpm}$ & $25 \mathrm{gpm}$ & $8 \mathrm{gpm}$ & $5.0 \mathrm{ft}^{3}$ \\
\hline Item & Cost & \multicolumn{3}{c}{ Quantity } \\
Krudico 15 gpm Ion Exchange Unit & $\$ 10,000$ & \multicolumn{2}{c}{1} \\
Sybron SR-7 Resin & $\$ 280 / \mathrm{ft}^{3}$ & \multicolumn{2}{c}{$5 \mathrm{ft}^{3}$} \\
\hline
\end{tabular}

This ion exchange unit operates as an alternating dual tank system. Both tanks are operating in parallel until a preset volume of water has passed through the flow totalizer. Regeneration of Column \#1 will be initiated automatically by the programmable logic controller. Column \#1 will 
return to service as soon as the regeneration cycle has been completed (98 minutes), thereby allowing regeneration of Column \#2. Alternatively, this unit can be run in a single tank mode where only Column \#1 is operated.

Pilot studies were conducted at the B834 treatment facility, Site 300. Groundwater from the treatment facility, which had been treated to remove VOCs, served as the influent source for the ion exchange unit as shown in Figure 4. Since B834 operated in batch mode, it was necessary to collect the batches of influent water in dual 1,000 gallon misting tanks before the tests could begin. Groundwater was run through the ion exchange unit and collected in a 2,000 gallon storage tank. When the influent misting tanks were drained, nitrate treated water was returned to the misting tanks and subsequently discharged (via air misting). The regeneration waste was collected in lined 55 gallon drums.

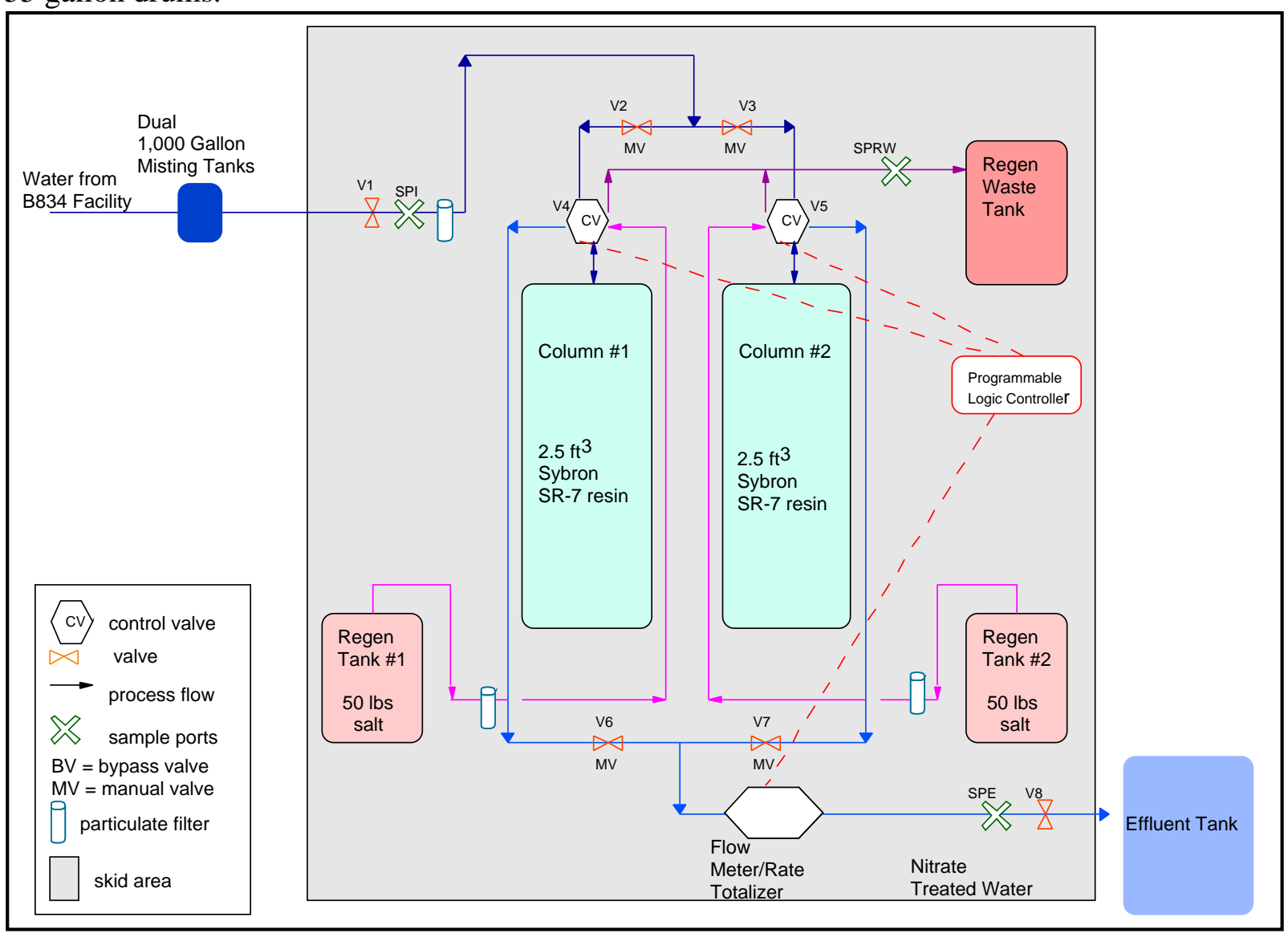

Figure 4: Process and instrumentation diagram for ion exchange unit when deployed during pilot tests at the B834 treatment facility.

Although the regeneration waste is not considered hazardous, the wastewater could not be disposed of through the sanitary sewer. The wastewater salt concentration was well above the City of Livermore discharge limits. Filled waste drums were shipped to the Hazardous Waste Management (HWM) group's interim storage facility. Drums were then disposed of as industrial wastewater. ${ }^{6,7}$ 


\section{ION EXCHANGE PILOT TESTING}

\section{Summary of procedure to test nitrate removal}

Three different trials were conducted during this pilot study to measure the unit's efficiency for removal of nitrate only. The complete test procedure is included in Appendix A. The data for all of the trials is included in Appendix B. In Trial A, data was analyzed using Hach field test kits rather then laboratory analysis by ion chromotography. Due to the high variability of the Hach test kits results, Trial A data are not considered in this report. The Hach test kit results are included in Appendix C.

In the interest of time, the ion exchange unit was run in single column mode. Treated water from B834 had an average influent concentration of $43 \mathrm{mg} / \mathrm{L} \mathrm{NO}_{3}{ }^{-}$(below the MCL). Therefore, the influent water was spiked to approximately $100 \mathrm{mg} / \mathrm{L} \mathrm{NO}_{3}{ }^{-}$for Trials B and C. Samples were collected at approximately 1.5 hour intervals. The unit was run until breakthrough was observed. The operating column was then regenerated. All samples collected during Trials B and C were analyzed by BC Laboratories, Bakersfield.

Perchlorate bench top study

Two bench top batch experiments were performed to determine the ability of the Sybron SR-7 to remove perchlorate from nitrate contaminated groundwater. A complete description of these tests and the results are included in Appendix D.

The first experiment determined whether or not Sybron SR-7 is capable of removing perchlorate from Site 300 nitrate contaminated groundwater. Four liters of Site 300 groundwater were spiked to a perchlorate concentration of $27 \mu \mathrm{g} / \mathrm{L}$. The nitrate concentration was estimated to be $60 \mathrm{mg} / \mathrm{L}$ $\mathrm{NO}_{3}^{-}$. The water was poured through a column (3" inch diameter) filled with Sybron SR-7 resin $\left(46\right.$ inches $\left.^{3}\right)$. Samples were taken when 2 and 3.5 liters of groundwater had passed through the column. The water flowed through the column at approximately $0.62 \mathrm{gpm}$, or $17 \%$ greater than the required minimum flow rate for this quantity of resin.

The second experiment sought to determine the selectivity of the resin for perchlorate over that of nitrate. A sample of resin ( 0.5 grams $)$ was pre-saturated with nitrate by immersion in a nitrate solution $\left(300 \mathrm{mg} / \mathrm{L} \mathrm{NO}_{3}{ }^{-}\right)$and mixed for 24 hours. The same resin was then transferred to a solution containing $130 \mu \mathrm{g} / \mathrm{L}$ perchlorate and approximately $105 \mathrm{mg} / \mathrm{L} \mathrm{NO}_{3}{ }^{-}$. This mixture was agitated for 24 hours. The second solution was analyzed for perchlorate concentrations before and after exposure to the resin. Perchlorate concentrations were measured by CalTest Laboratories, Napa.

\section{RESULTS AND DISCUSSION}

\section{Removal of nitrates}

The combined data from Trials $\mathrm{B}$ and $\mathrm{C}$ are presented in Figure 5. The weighted average influent concentration was $100 \mathrm{mg} / \mathrm{L} \mathrm{NO}_{3}{ }^{-}$for both trials. A greater operating time was achievable (prior to breakthrough) during Trial $\mathrm{C}$, hence greater error bars for the latter part of the effluent and removal efficiency curves. This is probably due to a more effective regeneration of the resin prior to Trial $\mathrm{C}$ compared to that preceding Trial B. Data from Trial A are not included here because the data were 
disrupted by numerous operational difficulties, as well as the high variability of the Hach test kit results.

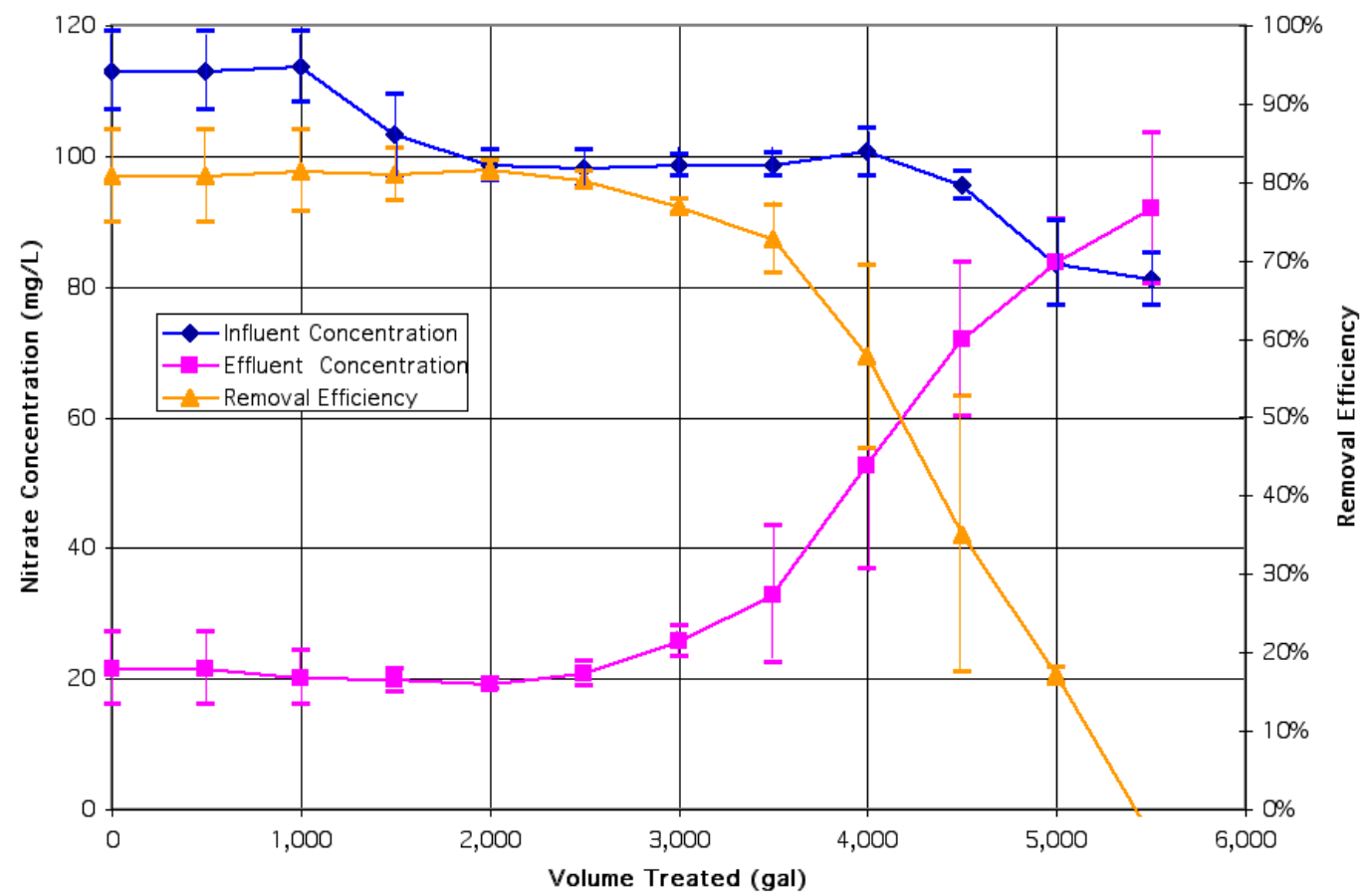

Figure 5: Combined removal efficiency and breakthrough data for Trials B and C using Sybron SR-7 resin during pilot testing. Average weighted influent nitrate concentration was $100 \mathrm{mg} / \mathrm{L} \mathrm{NO}_{3}{ }^{-}$.

Actual and predicted performance data are summarized in Table 3. The 817 target scenario results were obtained by using average experimental values (Trial B and Trial C) and breakthrough predictions from Sybron Resin literature (Appendix B). The regeneration removal efficiency was estimated to be $95 \%$. Krudico, Inc. predicted a removal rate of $92 \%$ to 93\%. Although Trial B reported a $100 \%$ removal rate, a more conservative $95 \%$ removal efficiency was assumed.

Table 3: Summary of performance statistics for Trial B, Trial C at the B834 test area and the Site 300, 817 target scenario during single column operation mode.

\begin{tabular}{|c|c|c|c|}
\hline Single Column Mode & Trial B & Trial C & $\begin{array}{c}\text { 817 Target } \\
\text { Scenario }^{\mathrm{a}}\end{array}$ \\
\hline Weighted Influent Concentration & 100.8 & 100.2 & 90.0 \\
\hline Effluent Concentration & 17.3 & 23.3 & 17.3 \\
\hline Average Removal Efficiency & $83.9 \%$ & $77.6 \%$ & $80.8 \%$ \\
\hline Gallons treated before breakthrough begun & 2,700 & 3,640 & 3,700 \\
\hline Mass of nitrate removed $(\mathrm{kg})$ during operation & 1.27 & 1.33 & 1.26 \\
\hline Regeneration Salt Type & $\begin{array}{c}\text { Fine Grain } \\
\text { Food Grade Salt }\end{array}$ & $\begin{array}{l}\text { Culligan } \\
\text { Solar Salt }\end{array}$ & $\begin{array}{l}\text { Culligan } \\
\text { Solar Salt }\end{array}$ \\
\hline Nitrate removed $(\mathrm{kg})$ during regeneration & 1.32 & 1.27 & 1.20 \\
\hline Calculated efficiency of regeneration cycle & $100 \%$ & $95.2 \%$ & $95.0 \%$ \\
\hline Gallons of regeneration waste produced & 69.2 & 70.9 & 70.0 \\
\hline Water treated to waste ratio & $39: 1$ & $51: 1$ & $52: 1$ \\
\hline
\end{tabular}


The data in Table 3 indicates that, when implemented in the 817 area at Site 300, the unit will need to be regenerated every 3,700 gallons, which is equivalent to 0.74 days. To allow for longer operation, both columns can be operated at a combined flow rate of $15 \mathrm{gpm}$. The unit would then be regenerated after 7,400 gallons (1.5 days) and produce 140 gallons of waste per cycle. The amount of nitrate leakage was estimated to be $17.3 \mathrm{mg} / \mathrm{L} \mathrm{NO}_{3}^{-}$.

Two different types of salt were tested during these tests. In Trial B, a fine grain food grade sodium chloride salt was used. This is also the salt currently used for regeneration of hexavalent chromium ion exchange resin at Treatment Facility D. Krudico suggested the use of a solar salt (diameter of approximately one centimeter). With the use of the solar salt, fewer problems were encountered and a higher salt concentration was observed in the regeneration brine (Figure 6). The food grade salt was difficult to dissolve and subsequently clogged the regeneration tank inflow line. Use of the food grade salt will require mixing prior to each regeneration, whereas solar salt can be left in the regeneration tanks where it will saturate the automatically refilled water over a relatively longer period of time. Additional salt must be added after the fourth regeneration cycle has been completed (or every five days at a $3.5 \mathrm{gpm}$ flow rate and a column flow rate of $15 \mathrm{gpm}$ ).

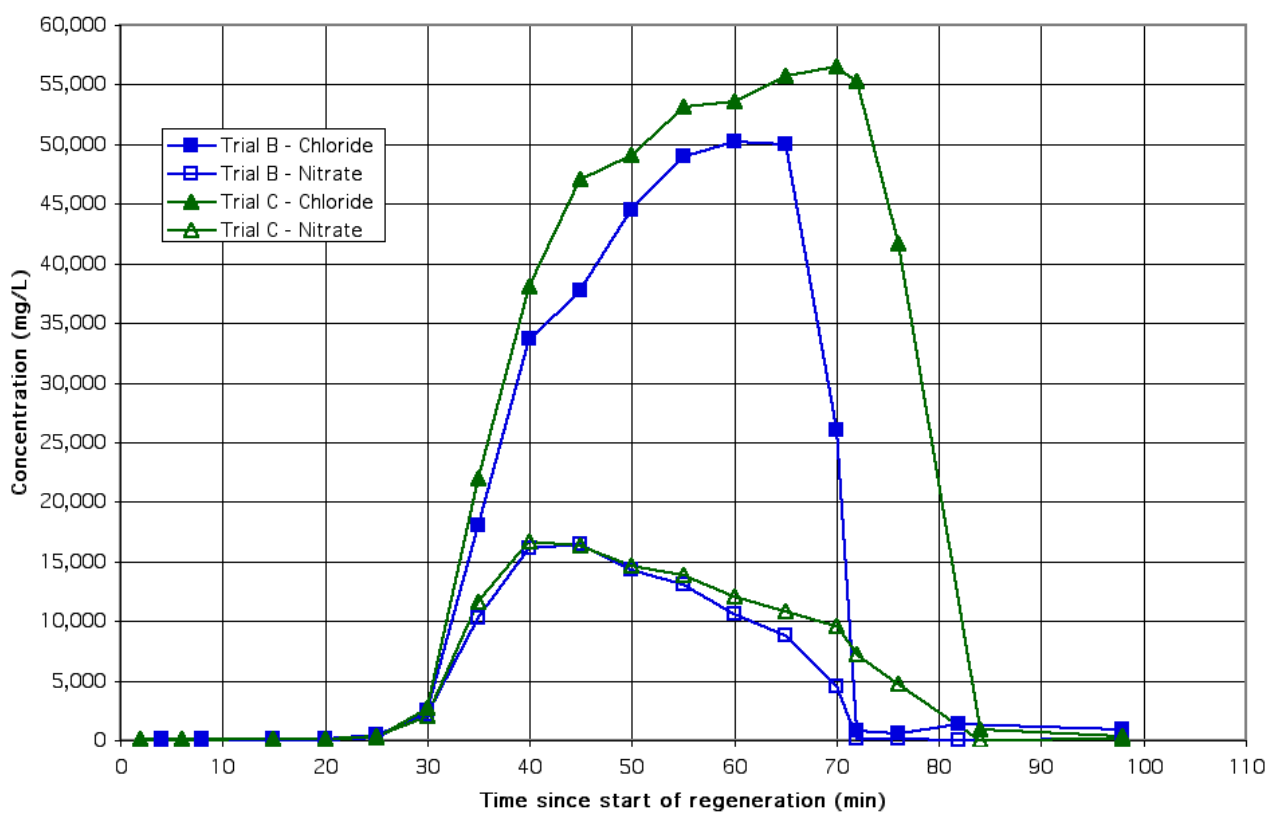

Figure 6: Nitrate and chloride concentrations versus time during regeneration of Trial B and Trial C. Fine grade food salt was used in Trial B. Solar salt was used in Trial C.

Although many commercial facilities using ion exchange technology can dispose of their waste via sanitary sewer, this is not the case at Site 300. The waste must be disposed of as industrial waste through the HWM group. ERD does not pay for these costs directly, but that may change at some point in the future. Therefore, the waste disposal costs are included in the cost estimate.

There are some modifications that can be made to reduce the volume of regeneration waste produced. Dennis Clifford, of the University of Houston, has conducted several studies to demonstrate a system in which the brine waste is recycled ${ }^{8}$. The brine is denitrified in a biological sequencing batch reactor and then recycled back into the system. This could reduce the amount of 
waste produced by up to $90 \%$, but this modification's suitability for application at Site 300 would still need to be determined. Another alternative is to not discard the first 20 minutes of the waste produced during the regeneration cycle, which is permissible because the initial wastewater is very low in both nitrate and chloride concentrations. Thus this water could be recycled back into the influent treatment tanks. The volume of waste produced could be reduced by $33 \%$ per regeneration cycle (water treated to waste ratio of 79:1). This would require either significant modification of the ion exchange unit or a technician to be present during each regeneration cycle to allow for separation of the first 20 minutes of the regeneration waste stream.

\section{Perchlorate treatment}

In the first bench scale test, the influent concentration of perchlorate was $27 \mu \mathrm{g} / \mathrm{L}$. According to lab analysis, the concentration was below the detection limit in both effluent samples. Similar results have been reported by other researchers. ${ }^{2}$

The results from the second bench scale test show that the perchlorate concentration in the second solution was non-detect after exposure to resin. This suggests that perchlorate has a higher affinity for the resins' functional group than nitrate does. The affinity may be so great that it will be extremely difficult to regenerate the resin. Another study used a similar Sybron resin and could only regenerate a fraction of the perchlorate loaded. The selectivity of the resin for perchlorate was 150 times greater then for chloride. ${ }^{2}$

One treatment option is to use the resin for perchlorate removal only and dispose of the saturated resin as hazardous waste. Theoretically, the unit can be run for up to three years (depending on the quantity, condition, and actual perchlorate selectivity of the resin) to treat $40 \mu \mathrm{g} / \mathrm{L}$ perchlorate groundwater to non-detectable levels. Experimental data and predictions are included in Appendix D. Before implementing this option, bench tests should be conducted to determine the minimum resin contact time needed for effective perchlorate removal.

\section{Cost analysis}

Several different applications of this technology have been suggested (Figure 7). The first option is to use the ion exchange unit only for treatment of nitrate. The second option is to treat only perchlorate and use a different technology to treat the nitrate contamination. The final option is to treat both nitrate and perchlorate with ion exchange technology. One column would be used to remove perchlorate. The next two columns would treat nitrate and be regenerated as normal. 


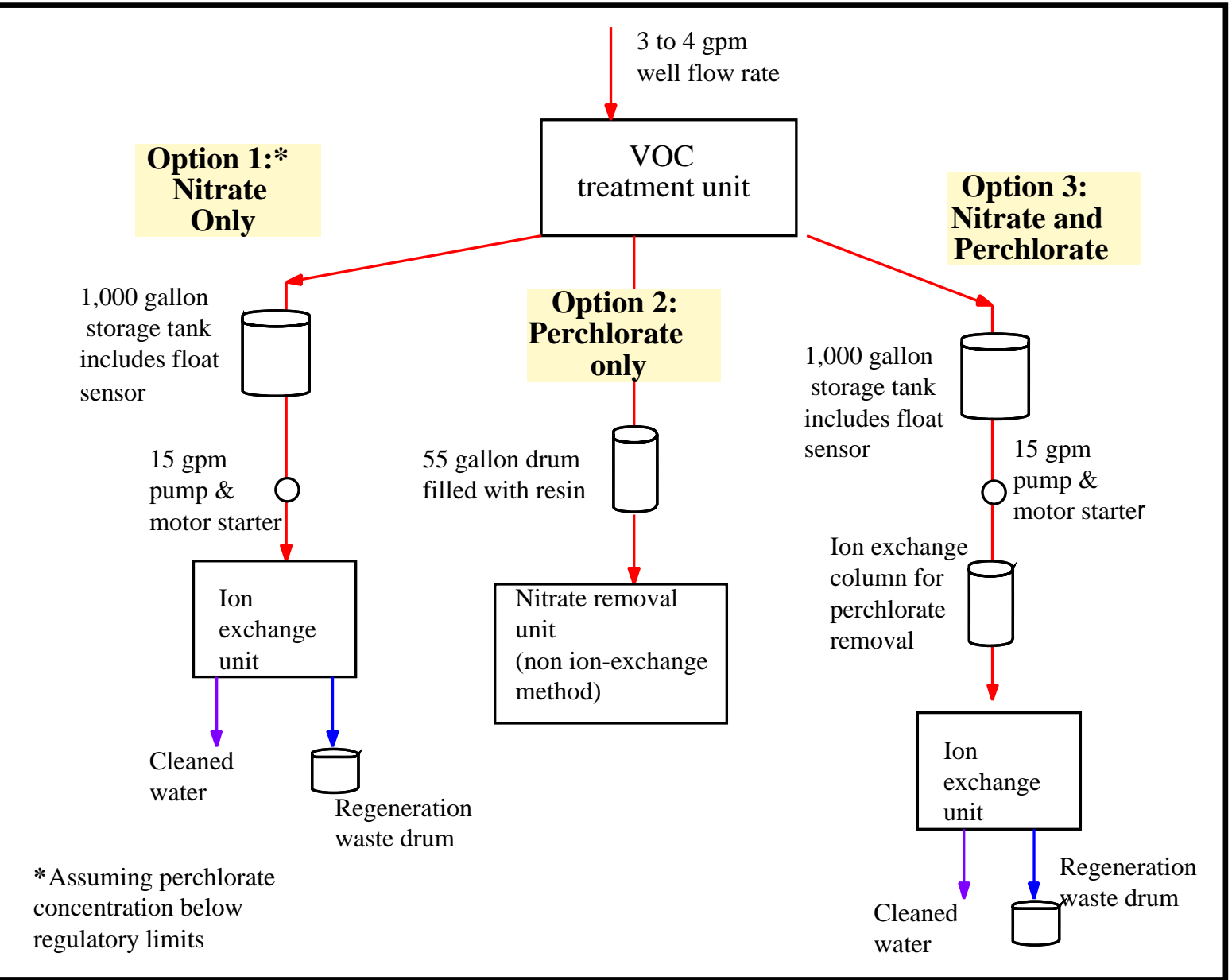

Figure 7: Overview diagram of various implementation options for the ion exchange unit.

Several modifications and operational considerations are necessary to include for the implementation of ion exchange at Site 300. Due to the high flow rate of the unit (7.5 to $15 \mathrm{gpm}$ ) compared to the scenario well flow rate of three to four gpm, it will be necessary to include a collection tank, automatic motor starter and appropriate controls for Options 1 and 3. Lower flow units are available, but would require a much more frequent regeneration. Options 1 and 3 will require fairly frequent maintenance, which includes refilling the regeneration tanks with salt, switching out regeneration waste drums, and monitoring the unit for nitrate breakthrough. The resin will also need to be replaced every two years in the nitrate removal ion exchange unit, due to calcium carbonate buildup (Options 1 and 3). The resin will need to be changed out every two to three years with Option 2 (Appendix D). Installation and operational costs associated with the various options are summarized in Table 4. The complete cost analysis is included in Appendix E. 
Table 4: Summary of costs associated with various treatment options.

\begin{tabular}{lccccc}
\hline & $\begin{array}{c}\text { Capital } \\
\text { Costs }\end{array}$ & $\begin{array}{c}\text { Total } \\
\text { Setup/Installation } \\
\text { Costs }\end{array}$ & $\begin{array}{c}\text { Operations and } \\
\text { Maintenance } \\
\text { Costs per year }\end{array}$ & $\begin{array}{c}\$ / \text { gallon } \\
\text { treated } \\
(\text { overall) }\end{array}$ & $\begin{array}{c}\text { \$ } \\
\text { treatlon } \\
\text { (yearly } \\
\text { O\&M) }\end{array}$ \\
\hline $\begin{array}{c}\text { Option 1 - } \\
\text { Nitrate Only }\end{array}$ & $\$ 15,700$ & $\$ 25,600$ & $\$ 258,400$ & $\$ 0.15$ & $\$ 0.14$ \\
$\begin{array}{c}\text { Option 2 - } \\
\text { Perchlorate Only }\end{array}$ & $\$ 2,300$ & $\$ 4,300$ & $\$ 37,200$ & $\$ 0.02$ & $\$ 0.02$ \\
$\begin{array}{c}\text { Option 3 - } \\
\text { Nitrate and }\end{array}$ & $\$ 17,700$ & $\$ 27,600$ & $\$ 263,300$ & $\$ 0.16$ & $\$ 0.14$ \\
Perchlorate & & & & & \\
\hline
\end{tabular}

${ }^{\mathrm{a}} \$$ /gallon water treated is based upon an annual average flow rate of $3.5 \mathrm{gpm}(1,839,600$ gallons total).

\section{CONCLUSION}

Ion exchange technology can be used to treat nitrate only. This usage has been well established and commercial units are easily available. This option is best implemented at wells with high flow rate and low concentrations of nitrate. With the addition of an influent storage tank, the test unit can be operated with intermittent or low flow wells. Unfortunately, a significant amount of regeneration waste is created in either case. Due to the high cost associated with waste disposal (\$220k per year), this technology may not be economically favorable. In addition, the leakage rate of $20 \%$ of the influent nitrate concentration may limit the application of this technology. If the discharge limits are set above $18 \mathrm{mg} / \mathrm{L}$, the effluent nitrate concentrations may be too high to meet these requirements.

Another option is to use the unit to treat perchlorate only. In this case, installation could be reduced to an initially maintenance free flow through box. After a few years, the perchlorate saturated resin would be disposed (\$350/year). This would be a low cost, low maintenance solution for the removal of perchlorate from groundwater. Nitrate could be treated with other technologies which include air misting, bioremediation, or phytoremediation.

A final option is to use ion exchange technology to remove both nitrate and perchlorate. A unit could be built with three ion exchange columns. The first column would serve for perchlorate removal by irreversible sorption, which would require disposal of the exhausted resin. The second two columns would be used to remove nitrate. Disadvantages of using this approach have already been discussed and are primarily of an economic nature.

In conclusion, ion exchange will be effective in treating both perchlorate and nitrate. It may be cost prohibitive when targeting nitrate due to the high cost of waste disposal. For perchlorate, a simple unit can be built and operated inexpensively. This method does not destroy the perchlorate, but it can be easily implemented and is likely to be very effective. 


\section{ACKNOWLEDGEMENTS}

I would like to also thank Tristan Pico and Ed Folsom for their guidance on this project. The technical support was provided by Marvin Lima and John Cunningham. Dick Woodward helped prepare the cost analysis.

\section{REFERENCES}

1. Kappor A, Viraraghavan T. "Nitrate Removal from Drinking Water - Review." Journal of Environmental Engineering. April 1997. 371: 380.

2. "Application of Ion-Exchange Technology for Perchlorate Removal from San Gabriel Basin Groundwater." Final project report submitted to Main San Gabriel Basin Watermaster by Montgomery Watson. April 6, 1999.

3. Harland, C.E. Ion Exchange: Theory and Practice. Royal Society of Chemistry. Cambridge, 1994.

4. Clifford, Dennis. Email conversation. March 4, 1999. DAClifford@UH.edu

5. Simon N, Kumamoto G, Pico T. "Removing Nitrate from Groundwater at Site 300 Using Ion Exchange." Lawrence Livermore National Labs. July 30, 1998. UCRL-ID-131062-98-1

6. Giesing, Ted. Memo from the Environmental Protection Department. December 4, 1998.

7. Mancieri, Sav. Memo from the Environmental Protection Department, Operations and Regulatory Affairs. May 4, 1999.

8. Clifford D, Liu X. "Ion Exchange with Denitrified Brine Reuse." Journal of American Water Works Association. 88.11 (1006): 88-99. 



\section{APPENDIX A}

Pilot Testing

Procedure 



\section{Nitrate Removal Ion Exchange Unit Optimization Studies - Pilot Testing Procedure 3X-046}

Written: $1 / 12 / 99$

Edited: $3 / 25 / 99$

\section{A-1.0 Purpose}

The purpose of this procedure is to outline the steps that will be followed in the optimization study of the nitrate removal ion exchange unit. This unit will be tested at Building 834 on Site 300. The goal is to minimize waste production, salt usage and maximize the service cycle length. Data collected will be used to develop a set of breakthrough curves for both nitrate and perchlorate removal. In addition, the capacity of the resin, regeneration cycle efficiency and an overall cost estimate will be determined. Several types of data will be collected: flow rates, salt usage, influent and effluent nitrate $\&$ chloride concentrations, and $\mathrm{pH}$ levels. This experiment was proceeded by a clean water flush at Livermore Site (LX-167).

\section{A-2.0 Scope}

The unit will be tested at Building 834 on Site 300 . The unit will be placed the misting pads. The influent line of the ion exchange unit will be connected to the two 1,000 gallon misting tanks located at B-834 misting pad. The two tanks will be filled with water from the B-834 treatment facility. The water will then pass through the ion exchange unit to two 1,000 gallon polyvinyl tanks. When the two misting tanks are empty, the water will be pumped back to the misting tanks and then air misted. This process will be repeated until a sufficient amount of water has flown through the ion exchange unit. This setup will allow for only a minimal impact on the Building 834 operations. Building 834 treatment facilities are designed to remove any VOC or TBOS contaminants from its influent water (well water). The effluent of B-834 will become the influent of the ion exchange unit. This water is refered to as "hard water" in this paper.

During the first part of this procedure, both tanks will be in service flow mode. In this stage, breakthrough curve data will be collected. Influent and effluent samples will be analyzed for chloride, nitrate and $\mathrm{pH}$ levels. These values will be plotted against bed volume (BV). Bed volume is defined as the volume of ion exchange resin material in the columns (or bed). After examining the plots, the maximum cycle length can be determined. Similar tests will be conducted using potassium perchlorate at a to be determined concentration, dependent on actual ambient influent perchlorate concentrations on a bench scale level. The resulting cycle lengths will be compared with predicted values based on the resin manufacturer's equations. In addition, nitrate leakage due to presence of sulfate will be recorded. 
The resin capacity will be determined using the influent and effluent nitrate concentration data. This is done by calculating the amount of nitrate entering the system and comparing it to the amount which exited the system before breakthrough. These results will be plotted against the varying concentrations of nitrates \& perchlorates and the number of cycles completed. This information will be particularly valuable for the analysis of perchlorate removal, as very few literature values exist.

The next part of this procedure begins when Tank \#1 begins to regenerate. The Programmable Logic Controller (PLC) has already been programmed for certain regeneration phase lengths. The first phase of the regeneration cycle is a backwash of the resin bed with hard water. The second phase is the brine tank fill/slow rinse. The resin tank is rinsed with the brine solution then slowly rinsed with hard water. The final phase of the regeneration cycle is the rapid rinse. During this stage, the residual brine waste will be rinsed off the resin with hard water. Tank \#1 will complete the regeneration cycle and return to service. Tank \#2 will be allowed to also complete a regeneration cycle. When tank \#2 has returned to service, the flow to the unit will be shut off.

Table A1 outlines the regeneration phase lengths and sampling plan. The goal of this phase of the study is to reduce the amount of regeneration waste solution produced and the amount of salt used. This can be achieved through several methods. For instance, the vendor suggests discharging the backwash stage and the first ten minutes of the brine tank fill/slow rinse cycle to the air misting pads since neither of those waste streams contain brine or elevated levels of nitrates. By monitoring the chloride levels, the brine content in the regeneration waste stream can be determined.

Table A1: Regeneration Cycle Lengths and Sampling Plan

\begin{tabular}{|l|l|l|l|}
\hline Cycle & PLC Setting & $\begin{array}{l}\text { Collection } \\
\text { Frequency }\end{array}$ & Analysis \\
\hline Backwash & 10 minutes & At 3 and 8 minutes & $\begin{array}{l}\text { Nitrate } \\
\text { pH }\end{array}$ \\
\hline Brine Tank Fill/Slow Rinse & 56 minutes & $\begin{array}{l}15 \text { minute intervals } \\
\text { At 30 minutes }\end{array}$ & $\begin{array}{l}\text { Chloride } \\
\text { Nitrate } \\
\text { pH }\end{array}$ \\
\hline Rapid Rinse & At 5 minutes & $\begin{array}{l}\text { Chloride } \\
\text { pH }\end{array}$ \\
\hline
\end{tabular}

The regeneration data will also be analyzed. The chloride and nitrate concentrations will be plotted against time from the start of each phase. The results will be interpreted to determine the necessary regeneration cycle lengths. The efficiency of the regeneration cycle will also be calculated. A nitrate removal rate of $90 \%$ to $92 \%$ is expected. The regeneration efficiency of perhclorate needs to be determined. Conversations with vendors and other people familiar with 
this topic suggests that the regeneration of the resins loaded with perchlorate may be difficult. Assuming a maximum perchlorate concentration of $30 \mathrm{ppb}$ and higher perchlorate affinity, perchlorate breakthrough is not expected until 13 million gallons have been treated.

After all collected data has been analyzed, modifications will be made to the PLC programming. This procedure will be repeated with the needed adjustments.

Nitrate levels will be measured with a Hach DR/890 colorimeter. The solution's acidity will be measured with $\mathrm{pH}$ strips. Chloride levels will be monitored with a YSI salinity meter. Various samples will be sent for a GENMIN analysis. The analysis will report the level of nitrate, sulfate, chloride, and bicarbonate in the effluent or influent sample. A perchlorate analysis will have been done prior to air misting by the B834 crew.

Overall expected performance, time and waste generation of unit with ambient nitrate conditions, most times are approximate and may vary depending on conditions of test. Table A2 outlines the beginning performance statistics.

Table A2: Summary of Initial Ion Exchange Operating Cycles

\begin{tabular}{|l|l|l|l|l|l|}
\hline Operation Mode & $\begin{array}{l}\text { Length } \\
\text { of Cycle }\end{array}$ & $\begin{array}{l}\text { Water } \\
\text { Source }\end{array}$ & $\begin{array}{l}\text { Discharge } \\
\text { Destination }\end{array}$ & $\begin{array}{l}\text { Flow } \\
\text { Rate } \\
\text { (gpm) }\end{array}$ & $\begin{array}{l}\text { Volume of } \\
\text { Water } \\
\text { Produced }\end{array}$ \\
\hline $\begin{array}{l}\text { Fill regeneration tanks with } \\
\text { salt }\end{array}$ & $5 \mathrm{~min}$ & None & none & none & None \\
\hline Service Flow & 5 hours & Influent & $\begin{array}{l}\text { Misting } \\
\text { Tanks }\end{array}$ & 15 & $\begin{array}{l}4000 \\
\text { gallons }\end{array}$ \\
\hline Backwash Position & $10 \mathrm{~min}$ & Influent & $\begin{array}{l}\text { Regen Waste } \\
\text { Tanks }\end{array}$ & 1.5 & 15 gal \\
\hline Brine draw/slow rinse & $56 \mathrm{~min}$ & $\begin{array}{l}\text { Regen } \\
\text { Tanks }\end{array}$ & $\begin{array}{l}\text { Regen Waste } \\
\text { Tanks }\end{array}$ & 0.8 & 84 gal \\
\hline Rapid Rinse & $6 \mathrm{~min}$ & Influent & $\begin{array}{l}\text { Regen Waste } \\
\text { Tanks }\end{array}$ & 1.5 & 9 gal \\
\hline Brine Tank Fill & $40 \mathrm{~min}$ & Influent & none & 15 & None \\
\hline
\end{tabular}


A-1.0

A-2.0

A-3.0 References

A-3.1 "NSF Equipment Verification Testing Plan for Nitrate Contaminant Removal by Ion Exchange Used in Package and/or Modular Drinking Water Systems for Small

Public or Private Water Supplies." NSF International. May 11, 1998.

\section{Procedure}

A-3.2 Notification of interested parties

A-3.2.1 Notify Ed Folsom \& Rolf Halden

A-3.2.2 Notify Rob Tagesson of Hazardous Waste Management Division

A-3.3 Pre-test setup

A-3.3.1 Collect the following:

A-a) DR 890 Colorimeter and nitrate ampules

A-b) YSI salinity meter

A-c) $\mathrm{pH}$ paper

A-d) Appropriate log book (ZB - Site 300 Misc. Log Book)

A-e) Sample bottles

A-f) Hazardous waste material tanks

A-3.4 Setup at Site 300 (see Figure 1)

A-3.4.1 Tighten all valves and connectors to prevent leaks

A-3.4.2 Release the straps from the fiberglass tanks

A-3.4.3 Connect influent line to the 1000 gallon tank located at the misting pad at B-834

A-3.4.4 Connect regeneration drain line to hazardous waste containers

A-3.4.5 Connect effluent line to misting tower or to appropriate tank 
A-3.4.6 Figure A1: Setup at Building 834

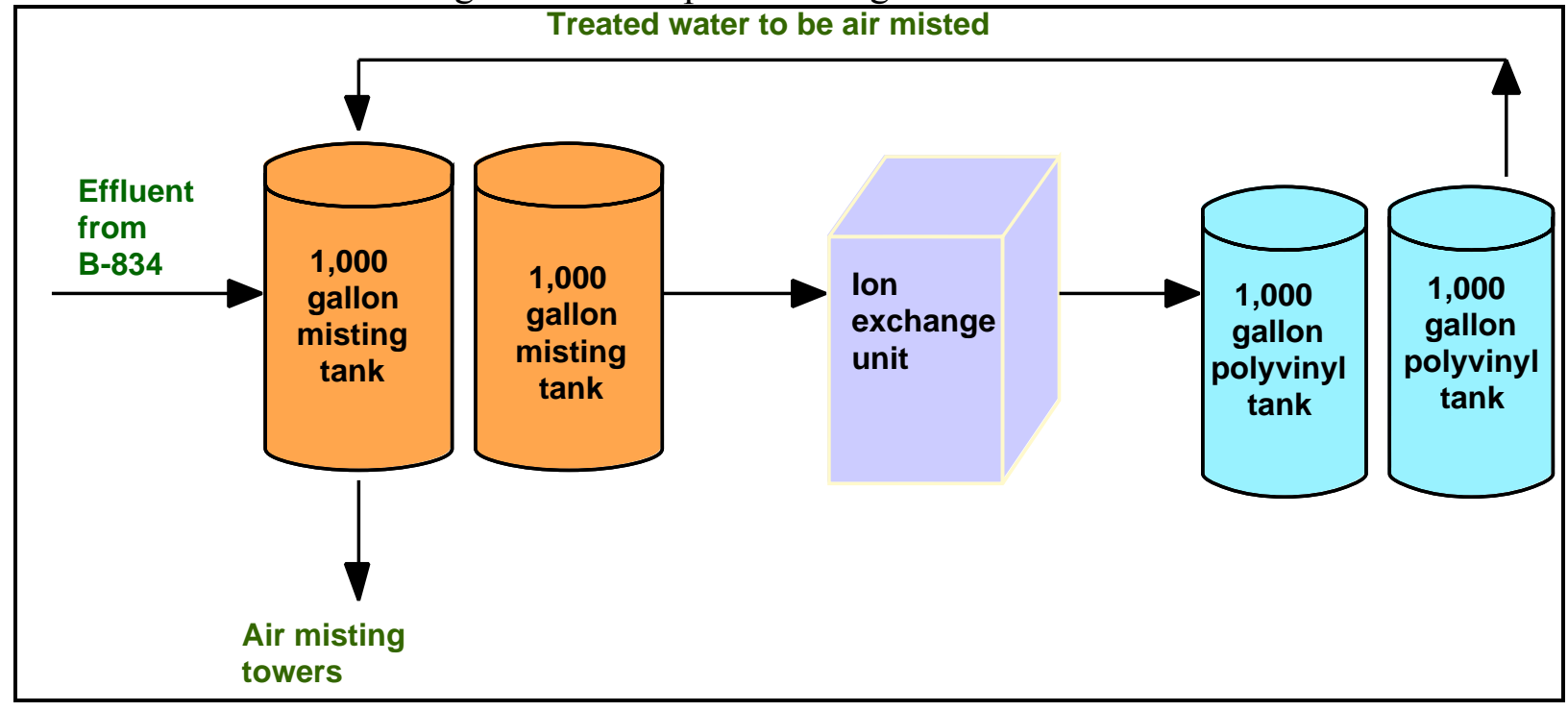

\section{A-4.0 Trial A Instructions}

A-4.1 Run water through unit (see Figure 2)

A-4.2 Turn PLC on.

A-4.3 Reset capacity setting to 15000 gallons.

A-4.4 Press and hold System Program button for 30 seconds

A-4.5 Press System Program button 7 times to advance to the Capacity setting

A-4.6 Using the up and down arrows, reset the total capacity to 8000 gallons

A-4.7 Return to normal operation by pressing the System Display button

A-4.8 Using PLC (Brine Draw/Slow Rinse setting), fill regeneration tanks with 10 gallons of water

A-4.9 Manually dump one half of a 50 pound bag of regeneration salt into each regeneration tank.

A-4.10 Open Valve 1 and Valve 8, allow water to flow through system.

A-4.11 Using flow rate meter, adjust influent pressure such that the flow is $15 \mathrm{gpm}$ by manipulating Valve 1. 
A-4.11.1 Figure A2: Overall System Layout and Labels

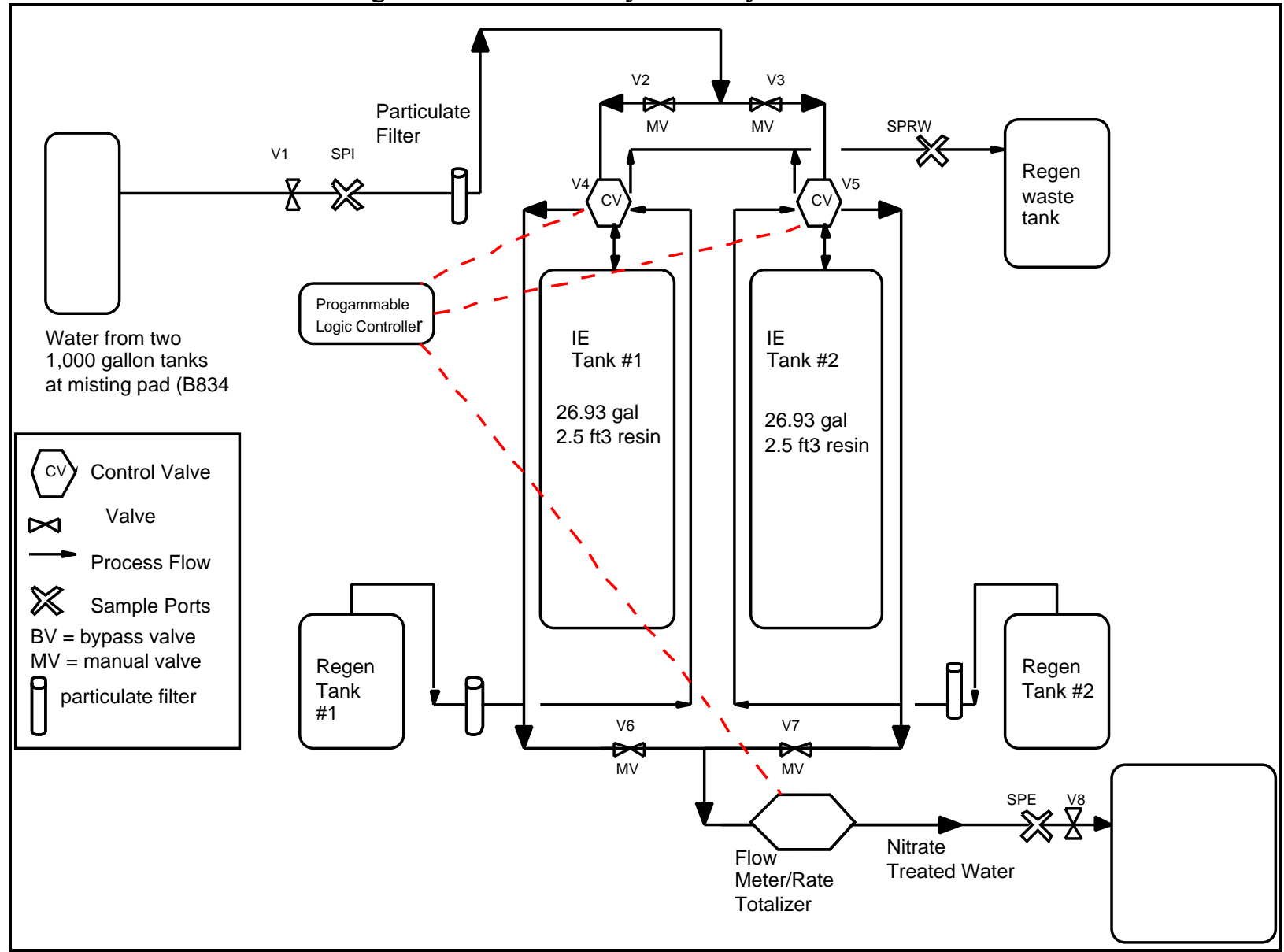

A-4.12 Collection of initial data (See Section 5.0 - Data Sheets)

A-4.13 Run 2,000 gallons of water through the unit, allow the water to be resent to B-834 and the tanks to be refilled. Repeat this practice until breakthrough is observed.

A-4.14 At 250 gallon intervals, collect influent and effluent samples. Using $\mathrm{pH}$ test strips, record $\mathrm{pH}$. Record nitrate levels using DR 790 colorimeter.

A-4.15 At 1000 gallon intervals, analyze the sample for chloride levels using the alkalinity meter.

A-4.16 Plot influent, effluent nitrate, $\mathrm{pH}$ and effluent levels against bed volume. Bed volume is calculated by dividing the total flow reading by 18.70 gallons (or $2.5 \mathrm{ft}^{3}$ of resin).

A-4.17 Compare breakthrough point with that predicted by Sybron literature (see attached calculations!)

A-4.18 Regeneration of Tank \#1

A-4.18.1 Stage 1: Backwash

A-a) This stage lasts 10 minutes (backwashes resin with hard water)

A-b) Collect nitrate and $\mathrm{pH}$ sample at 3 and 8 minutes

A-4.18.2 Stage 2: Brine Tank Fill/Slow Rinse

A-a) This stage lasts 56 minutes (washes resin with brine water) 
A-b) Collect chloride sample at 30 minutes

A-c) Collect nitrate and $\mathrm{pH}$ samples at 15 minute intervals

A-d) Using YSI chloride meter, monitor chloride levels. Record time when chloride levels return to ambient levels

A-4.18.3 Stage 3: Rapid rinse

A-a) This stage lasts 6 minutes (rapidly rinses resin with hard water)

A-b) Collect a chloride and $\mathrm{pH}$ sample at 4 minutes

A-c) Allow Tank \#1 to go back into service and Tank \#2 to complete regeneration cycle

A-d) Turn flow of water off to unit

A-5.0 Trial B Instructions

A-5.1 Run water through unit

A-5.2 Set PLC for single tank mode.

A-5.3 Press and hold System Program button for 30 seconds

A-5.4 Press System Program button 2 times to advance to the Unit Size setting A-5.4.1 Using the up and down arrows, reset the unit size to one

A-5.4.2 Return to normal operation by pressing the System Display button

A-5.5 The PLC will automatically begin to regenerate. A small ' $r$ ' will be visible on the PLC screen. Halt the regeneration cycle by unplugging the PLC and waiting 30 seconds. Plug PLC back in and progress to next step. Switching the PLC to single tank mode while in operation is the signal for the PLC to begin a regeneration cycle.

A-5.6 Using PLC (Brine Draw/Slow Rinse setting), fill regeneration tanks with 10 gallons of water. If there is water already in the brine tank, determine whether or not the water is clean (ie does not contain regeneration waste). For Trial B, the water will need to be removed and disposed of in a hazardous waste drum. The brine tank water has high concentrations of salt and nitrates due to incomplete regeneration in Trial A.

A-5.7 Manually dump one half of a 50 pound bag of regeneration salt into each regeneration tank $(25 \mathrm{lbs})$. Use mixer to sufficiently agitate water and salt.

A-5.8 Open Valve 1 and Valve 8, allow water to flow through system.

A-5.9 Using flow rate meter, adjust influent pressure such that the flow is $15 \mathrm{gpm}$ (or 30 liters per minute) by manipulating Valve 1.

A-5.10 Collection of initial data (See Section 5.0 - Data Sheets)

A-5.11 Take sample of water in B834 misting tanks. Using Hach Colormeter, determine initial nitrate concentration. Use attached spreadsheet to calculate how much sodium nitrate must be added to get a final solution of $100 \mathrm{ppm}$. Analyze final solution with Hach kit and a dilution of 5:1. (Read height of water in misting tanks from B834. 56" represents 2000 gallons).

A-5.11.1 Run volume of water in misting tanks through the ion exchange unit, collecting effluent in large 2000 gallon tank.

A-5.12 At one hour intervals, collect influent and effluent samples. Using $\mathrm{pH}$ test strips, record $\mathrm{pH}$. Record nitrate and sulfate levels using DR 790 colorimeter. 
A-5.13 When the misting tanks are drained, open valves between large 2000 gallon tank and drain the water back into the misting tanks. Re-spike water to $100 \mathrm{pm}$ and repeat procedure until breakthrough is observed. Water may be air misted when required by $\mathrm{B} 834$ technicians

A-5.14 Plot influent, effluent nitrate, $\mathrm{pH}$ and effluent levels against bed volume. Bed volume is calculated by dividing the total flow reading by 18.70 gallons (or $2.5 \mathrm{ft}^{3}$ of resin). Also plot the removal efficiency versus the volume of water treated.

A-5.15 Compare breakthrough point with that predicted by Sybron literature (see Calculations) using weighted average influent nitrate concentrations.

A-5.16 Regeneration of Tank \#1

A-5.17 When breakthrough has been achieved, a regeneration of Tank 1 will need to be initiated. This involves several steps including resetting the PLC to two tank mode and changing the lengths of the various PLC settings.

A-5.18 Press and hold System Program button for 30 seconds

A-5.19 Press System Program button 2 times to advance to the Unit Size setting

A-5.20 Using the up and down arrows, reset the unit size to one

A-5.21 Press System Program button to advance to Regeneration Cycle Mode. Change the brine draw/slow rinse setting to 160 minutes (In the previous trial, it was determined that the initial setting was too short to complete the brine draw and slow rinse cycle. Only the brine draw phase was completed in Trial A).

A-5.22 Return to normal operation by pressing the System Display butt

A-5.23 Stage 1: Backwash

A-5.23.1 This stage lasts 10 minutes (backwashes resin with hard water)

A-5.23.2 Collect nitrate and $\mathrm{pH}$ sample at 3 and 8 minutes

A-5.24 Stage 2: Brine Tank Fill/Slow Rinse

A-5.25 This stage lasts for an undetermined time (rinses resin with brine water, rinses brine water off resin). Using the salinity meter, sample frequently to determine when the water coming from the regeneration waste line is free of salt. Record time when all brine has been drawn from tank. Record time when all brine has been rinsed from column.

A-5.26 Collect samples as described on data sheets.

A-5.27 Stage 3: Rapid rinse

A-5.27.1 This stage lasts 6 minutes (rapidly rinses resin with hard water)

A-5.27.2 Collect a chloride and $\mathrm{pH}$ sample at 3 and 6 minutes

A-5.27.3 Stop PLC from regenerating Tank Two by advancing out of regeneration cycle. Press Manual Regneration Button (or Unit 2 Display) to step the unit through the various regeneration cycles.

A-5.28 Turn flow of water off to unit 


\section{APPENDIX B}

Data 

Trial A Data 

TRIAL A - Raw Data

Nitrate data was determined using Hach Test kits

\begin{tabular}{|c|c|c|c|c|c|c|c|c|}
\hline Date & Time & $\begin{array}{c}\text { Total Flow } \\
\text { Reading liters }\end{array}$ & $\begin{array}{c}\text { Flow Rate } 1 \\
\text { pm }\end{array}$ & $\begin{array}{c}\text { Influent } \\
\text { Nitrate } \mathbf{m g} / \mathbf{L}\end{array}$ & $\mathrm{pH}$ & $\begin{array}{l}\text { Effluent } \\
\text { Nitrate } \\
\mathrm{mg} / \mathrm{L}\end{array}$ & pH & Notes \\
\hline \multirow{5}{*}{$1 / 21 / 99$} & $12: 41$ & 1762 & 59.1 & & & & & \\
\hline & & 2783 & 58.3 & & & & & \\
\hline & $13: 25$ & 4054 & 58.2 & & & & & \\
\hline & & 4123 & & 8.5 & 7 & 0.3 & 7 & \\
\hline & $13: 45$ & 5226 & & & & & & \\
\hline \multirow[t]{9}{*}{$1 / 27 / 99$} & $9: 32$ & 5226 & & & & & & \\
\hline & & 5238 & & & & & & $\begin{array}{l}\text { Switched PLC to run one one column at } 7.5 \mathrm{gpm} / \text { column, } \\
\text { outdoor flow meter stuck at } 1 \mathrm{gpm} \text {, PLC stopped reading flow, } \\
\text { operation stopped }\end{array}$ \\
\hline & & 5983 & 30.8 & & & & & $\begin{array}{l}\text { Don fixed outdoor flow meter, PLC iniated regeneration, } \\
\text { Marvin halted, turned all valves to lag tank shut, test resumed }\end{array}$ \\
\hline & $10: 12$ & 5999 & 31.2 & & & & & \\
\hline & $11: 00$ & 7358 & 30 & & & & & $\begin{array}{l}\text { Sulfate measured at } 80 \mathrm{ppm}+(\text { beyond limits of colorimeter?), } \\
\text { realized that have been doing nitrate analysis wrong! need to } \\
\text { zero with sample not di water, } 1 / 28 / 99 \text { redid suflate test } \\
\text { with correct blank still read } 80+\end{array}$ \\
\hline & & 7376 & & 9.45 & & 0.9 & & Eric performed chemetrics test also. Got 6.55 as N!! \\
\hline & $12: 30$ & 10245 & 30 & & & & & \\
\hline & & 11513 & & 8.9 & & 0.3 & & \\
\hline & & 11547 & 29.9 & & & & & \\
\hline \multirow[t]{5}{*}{$2 / 3 / 99$} & $10: 09$ & 11583 & & & & & & Concentrations may be so low due to recent heavy rains. \\
\hline & $11: 37$ & 14216 & 30 & & & & & \\
\hline & & 14256 & & 5.7 & 7 & 0.7 & 7 & \\
\hline & $13: 31$ & 17647 & 29.9 & 5.1 & & 0.5 & & \\
\hline & $14: 25$ & 19240 & & & & & & \\
\hline \multirow{4}{*}{$2 / 9 / 99$} & $11: 49$ & 19241 & 30.8 & & & & & Exterior flow meter not working \\
\hline & $13: 33$ & 22505 & 31.7 & 5.3 & & 0.6 & & More rain.... \\
\hline & $15: 15$ & 25749 & 31.7 & 5.7 & & 0.7 & & \\
\hline & $15: 59$ & 26033 & & & & & & \\
\hline \multirow[t]{6}{*}{$2 / 16 / 99$} & $10: 35$ & 27747 & 29.7 & 5.45 & & & & Spiking attempt\#1 \\
\hline & & 27932 & & 11.1 & & 2.5 & & \\
\hline & $11: 38$ & 20606 & 29.6 & & & & & \\
\hline & & 29636 & & 11.6 & & 2.9 & & \\
\hline & $12: 46$ & 31631 & 29.6 & 12.8 & & 3.3 & & \\
\hline & $13: 31$ & 33152 & 29.7 & 12.1 & & 3.6 & & Took sample of water before filter, $10.4 ! !$ \\
\hline \multirow[t]{4}{*}{$2 / 19 / 99$} & $12: 25$ & 34269 & 28.2 & 74.4 & & 28 & & Switched colorimeter to read NO3 rather then N \\
\hline & $13: 04$ & 35404 & 29.3 & 83.2 & & 43 & & Spiking attempt \#2 \\
\hline & $13: 30$ & 36165 & 29.5 & 78 & & 56.6 & & \\
\hline & $13: 58$ & 36991 & 29.7 & 71.8 & & 60.6 & & \\
\hline & & & & & & & & \\
\hline \multirow[t]{4}{*}{$3 / 2 / 99$} & $12: 42$ & 47539 & 30 & 86.6 & & 27.4 & & Regen attempt failed, fixed regen cycle, resaturated column \\
\hline & $14: 18$ & 50480 & 30 & 67.4 & & 25.5 & & \\
\hline & & 50750 & 30 & 64.7 & & 70.7 & & \\
\hline & $15: 20$ & 52345 & & & & & & \\
\hline \multirow[t]{3}{*}{$3 / 3 / 99$} & $11: 00$ & 52666 & 30.9 & & & & & \\
\hline & & 56866 & & 76.2 & & 72 & & \\
\hline & $13: 51$ & 57863 & 30.5 & 68 & & 77.6 & & breakthrough achieved again \\
\hline
\end{tabular}




\section{TRIAL A - Breakthrough Curve Data}

\begin{tabular}{|c|c|c|c|c|c|c|c|c|c|}
\hline & \multicolumn{9}{|c|}{ All values used are from actual Hach Kit readings } \\
\hline & $\begin{array}{l}\text { Flow Meter } \\
\text { Reading } \\
\text { (liters) }\end{array}$ & $\begin{array}{c}\text { Total Flow } \\
\text { (liters) }\end{array}$ & $\begin{array}{l}\text { Influent } \\
\text { NO3 Conc } \\
(\mathrm{mg} / \mathrm{L})\end{array}$ & $\begin{array}{l}\text { Effluent } \\
\text { NO3 Conc } \\
\text { (mg/ L) }\end{array}$ & $\begin{array}{c}\text { Influent } \\
\text { NO3 amount } \\
\text { (g) }\end{array}$ & $\begin{array}{c}\text { Effluent } \\
\text { NO3 Amount } \\
(\mathrm{g})\end{array}$ & $\begin{array}{l}\text { Nitrate } \\
\text { Removed } \\
\text { (g) }\end{array}$ & $\begin{array}{l}\text { Removal } \\
\text { Efficiency }\end{array}$ & Notes \\
\hline Batch \#1 & & 617 & 34.99 & 2.21 & 21.59 & 1.37 & 20.23 & $93.67 \%$ & \\
\hline \multirow[t]{2}{*}{$1 / 21 / 99$} & & 1155 & 40.30 & 3.54 & 20.24 & 1.55 & 18.69 & $92.35 \%$ & \\
\hline & & 2335 & 37.64 & 2.21 & 46.01 & 3.40 & 42.61 & $92.61 \%$ & \\
\hline Batch \#2 & 7376 & 4485 & 41.85 & 3.99 & 85.45 & 6.67 & 78.79 & $92.20 \%$ & \\
\hline \multirow[t]{3}{*}{$1 / 27 / 99$} & 10267 & 7376 & 43.18 & 2.21 & 122.91 & 8.96 & 113.95 & $92.71 \%$ & \\
\hline & 11313 & 8422 & 43.18 & 4.43 & 45.16 & 3.47 & 41.69 & $92.31 \%$ & \\
\hline & 11513 & 8622 & 39.41 & 2.21 & 8.26 & 0.66 & 7.60 & $91.96 \%$ & \\
\hline Batch \#3 & 14256 & 11365 & 25.24 & 3.10 & 88.68 & 7.29 & 81.39 & $91.78 \%$ & Heavy rains \\
\hline $2 / 3 / 99$ & 17647 & 14756 & 22.59 & 2.21 & 81.09 & 9.01 & 72.08 & $88.89 \%$ & \\
\hline Batch \#4 & 22505 & 19614 & 23.47 & 2.66 & 111.87 & 11.83 & 100.04 & $89.42 \%$ & Heavy rains \\
\hline $2 / 9 / 99$ & 25749 & 22858 & 25.24 & 3.10 & 79.01 & 9.34 & 69.68 & $88.18 \%$ & \\
\hline Batch \#5 & 27932 & 25041 & 49.16 & 11.07 & 81.21 & 15.47 & 65.74 & $80.95 \%$ & Still raining \\
\hline \multirow[t]{3}{*}{$2 / 10 / 99$} & 29636 & 26745 & 51.37 & 12.84 & 85.65 & 20.37 & 65.28 & $76.21 \%$ & Spiked \\
\hline & 31631 & 28740 & 56.69 & 14.61 & 107.79 & 27.39 & 80.40 & $74.59 \%$ & \\
\hline & 33152 & 30261 & 53.59 & 15.94 & 83.86 & 23.24 & 60.62 & $72.29 \%$ & \\
\hline Batch \#6 & 34269 & 31378 & 74.40 & 28.00 & 71.48 & 24.54 & 46.94 & $65.67 \%$ & Spiked \\
\hline \multirow[t]{11}{*}{$2 / 19 / 99$} & 35404 & 32513 & 83.20 & 43.00 & 89.44 & 40.29 & 49.15 & $54.95 \%$ & \\
\hline & 36165 & 33274 & 78.00 & 56.60 & 61.34 & 37.90 & 23.44 & $38.21 \%$ & \\
\hline & 36991 & 34100 & 71.80 & 60.60 & 61.87 & 48.40 & 13.46 & $21.76 \%$ & \\
\hline & 37956 & 35065 & 69.80 & 69.20 & 68.32 & 62.63 & 5.69 & $8.33 \%$ & \\
\hline & 38825 & 35934 & 72.40 & 70.20 & \begin{tabular}{|l|}
61.79 \\
\end{tabular} & 60.57 & 1.22 & $1.97 \%$ & \\
\hline & & & & \multicolumn{3}{|c|}{ Average Influent Nitrate Concentration: } & \multicolumn{2}{|l|}{49.40} & \\
\hline & & & & \multicolumn{3}{|c|}{ Total Nitrate Removed $(\mathrm{kg})$ : } & \multicolumn{2}{|l|}{1.06} & \\
\hline & & & & \multicolumn{3}{|c|}{ Weighted Average Influent Concentration: } & 41.27 & & \\
\hline & & & & \multicolumn{3}{|c|}{ Weighted Average Effluent Concentration: } & 11.81 & & \\
\hline & & & & \multirow{2}{*}{\multicolumn{3}{|c|}{ Total Liters Treated: }} & 35934 & & \\
\hline & & & & & s Treated: & & 9491 & & \\
\hline
\end{tabular}


Trial A - Breakthrough Chart

Actual Hach Kit readings

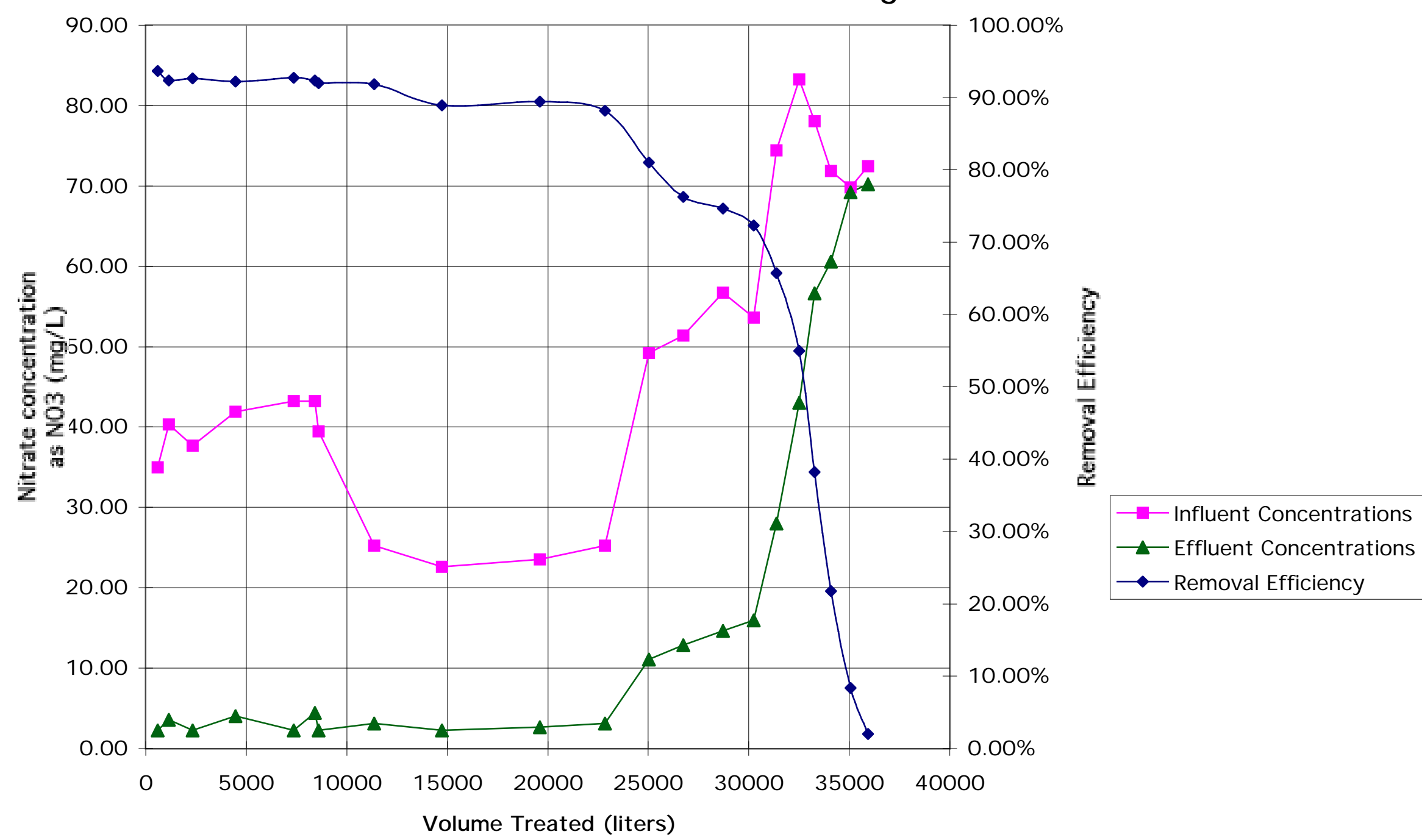


TRIAL A - Breakthrough Data

Nitrate values are from Hach kit readings, unless using spiked water when predicted value was used instead of Hach Data

\begin{tabular}{|c|c|c|c|c|c|c|c|c|}
\hline & $\begin{array}{c}\text { Total Flow } \\
\text { (liters) }\end{array}$ & $\begin{array}{l}\text { Influent } \\
\text { NO3 Conc } \\
\text { (mg/ L) }\end{array}$ & $\begin{array}{c}\text { Corrected } \\
\text { Influent NO3 } \\
\text { (mg/ L) }\end{array}$ & $\begin{array}{l}\text { Effluent } \\
\text { NO3 Conc } \\
\text { ( } \mathrm{mg} / \mathrm{L})\end{array}$ & $\begin{array}{c}\text { Influent } \\
\text { NO3 amount } \\
\text { (g) }\end{array}$ & $\begin{array}{c}\text { Effluent } \\
\text { NO3 Amount } \\
\text { (g) }\end{array}$ & $\begin{array}{l}\text { Nitrate } \\
\text { Removed } \\
\text { (g) }\end{array}$ & $\begin{array}{l}\text { Removal } \\
\text { Efficiency }\end{array}$ \\
\hline Batch \#1 & 617 & 34.99 & 34.99 & 2.21 & 21.59 & 1.37 & 20.23 & $93.67 \%$ \\
\hline \multirow[t]{2}{*}{$1 / 21 / 99$} & 1155 & 40.30 & 40.30 & 3.54 & 20.24 & 1.55 & 18.69 & $92.35 \%$ \\
\hline & 2335 & 37.64 & 37.64 & 2.21 & 46.01 & 3.40 & 42.61 & $92.61 \%$ \\
\hline Batch \#2 & 3305 & 41.85 & 41.85 & 3.99 & 38.53 & 3.01 & 35.53 & $92.20 \%$ \\
\hline \multirow[t]{3}{*}{$1 / 27 / 99$} & 6196 & 43.18 & 43.18 & 2.21 & 122.91 & 8.96 & 113.95 & $92.71 \%$ \\
\hline & 7242 & 43.18 & 43.18 & 4.43 & 45.16 & 3.47 & 41.69 & $92.31 \%$ \\
\hline & 7442 & 39.41 & 39.41 & 2.21 & 8.26 & 0.66 & 7.60 & $91.96 \%$ \\
\hline Batch \#3 & 10185 & 25.24 & 25.24 & 3.10 & 88.68 & 7.29 & 81.39 & $91.78 \%$ \\
\hline $2 / 3 / 99$ & 13576 & 22.59 & 22.59 & 2.21 & 81.09 & 9.01 & 72.08 & $88.89 \%$ \\
\hline Batch \#4 & 18434 & 23.47 & 23.47 & 2.66 & 111.87 & 11.83 & 100.04 & $89.42 \%$ \\
\hline $2 / 9 / 99$ & 21678 & 25.24 & 25.24 & 3.10 & 79.01 & 9.34 & 69.68 & $88.18 \%$ \\
\hline Batch \#5 & 23861 & 49.16 & 171.00 & 11.07 & 214.20 & 15.47 & 198.73 & $92.78 \%$ \\
\hline \multirow[t]{3}{*}{$2 / 10 / 99$} & 25565 & 51.37 & 171.00 & 12.84 & 291.38 & 20.37 & 271.01 & $93.01 \%$ \\
\hline & 27560 & 56.69 & 171.00 & 14.61 & 341.15 & 27.39 & 313.76 & $91.97 \%$ \\
\hline & 29081 & 53.59 & 171.00 & 15.94 & 260.09 & 23.24 & 236.85 & $91.07 \%$ \\
\hline Batch \#6 & 30198 & 74.40 & 185.00 & 28.00 & 198.83 & 24.54 & 174.28 & $87.66 \%$ \\
\hline \multirow[t]{5}{*}{$2 / 19 / 99$} & 31333 & 83.20 & 185.00 & 43.00 & 209.98 & 40.29 & 169.68 & $80.81 \%$ \\
\hline & 32094 & 78.00 & 185.00 & 56.60 & 140.79 & 37.90 & 102.89 & $73.08 \%$ \\
\hline & 32920 & 71.80 & 185.00 & 60.60 & 152.81 & 48.40 & 104.41 & $68.32 \%$ \\
\hline & 33885 & 69.80 & 185.00 & 69.20 & 178.53 & 62.63 & 115.90 & $64.92 \%$ \\
\hline & 34754 & 72.40 & 185.00 & 70.20 & 160.77 & 60.57 & 100.20 & $62.32 \%$ \\
\hline & & & & \multicolumn{3}{|c|}{ Average Influent Nitrate Concentration: } & 49.4 & \\
\hline & & & & \multicolumn{3}{|c|}{ Total Nitrate Removed $(\mathrm{kg})$ : } & 2.3 & \\
\hline & & & & \multicolumn{3}{|c|}{ Weighted Average Influent Concentration: } & 80.9 & \\
\hline & & & & \multicolumn{3}{|c|}{ Weighted Average Effluent Concentration: } & 12.1 & \\
\hline & & & & \multicolumn{3}{|c|}{ Total Liters Treated: } & \multicolumn{2}{|c|}{34754} \\
\hline & & & & \multicolumn{3}{|c|}{ Total Gallons Treated: } & 917 & \\
\hline
\end{tabular}


TRIAL A - Breakthrough Curve

Hach kit data, w/ estimated influent concentrations for spiked samples

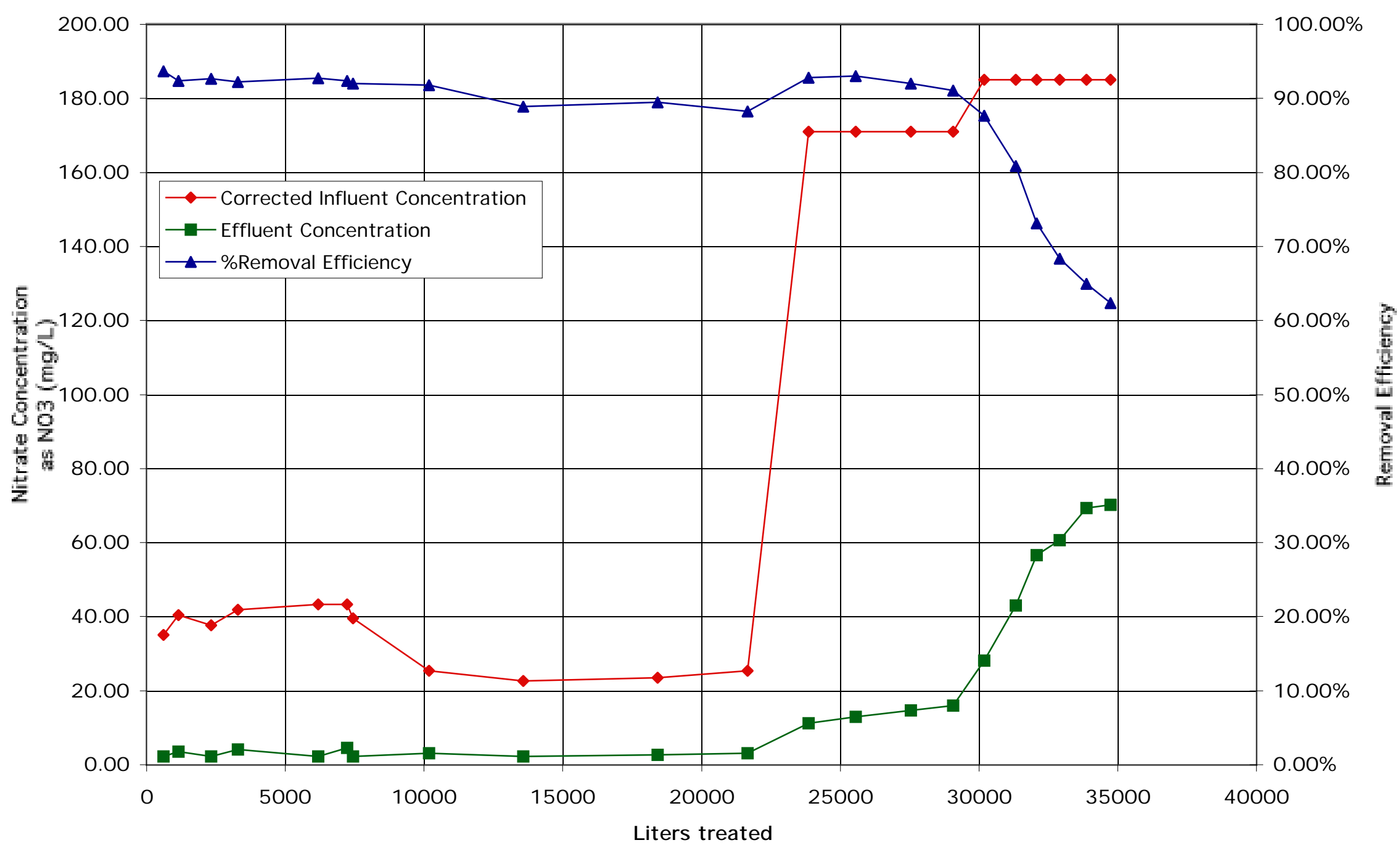




\section{TRIAL A - Breakthrough Predictions}

Sample calculations included in Appendix F

Using Hach Readings

\begin{tabular}{|l|c|c|c|}
\hline \multicolumn{1}{|c|}{ Other } & ppm* & Conversion & ppm, CaCO3 \\
\hline Contaminants & & Factor & \\
\hline Bicarbonate, $\mathrm{HCO} 3$ & 370 & 0.82 & 303.4 \\
\hline Sulfate, $\mathrm{SO} 4$ & 53 & 1.04 & 55.12 \\
\hline Chloride, $\mathrm{Cl}$ & 79 & 1.41 & 111.39 \\
\hline
\end{tabular}

* Taken from Genmin analysis run on 12/18/98 (TF-834-EFLU-B111-1300)

\begin{tabular}{|c|c|l|l|l|}
\hline Run \# & Nitrate Conc & Conversion & ppm, CaCO3 & grains/gal \\
\hline & (as NO3) ppm & Factor & & (as CaCO3) \\
\hline 1 & 41.27 & 0.81 & 33.43 & 1.95 \\
\hline & & & & \\
\hline & & & & \\
\hline
\end{tabular}

Step 1 - Percent Nitrate

Percent Nitrate $=(\mathrm{NO} 3 \mathrm{ppm}$ as $\mathrm{CaCO} 3) /(\mathrm{NO} 3 \mathrm{ppm}$ as $\mathrm{CaCO} 3+\mathrm{SO} 4 \mathrm{ppm}$ as $\mathrm{CaCO} 3)$

$\% \mathrm{NO3}=$

0.38

Step 2 - Nitrate Leakage

Read from Figure \#3 in Sybron literature (pg 3)

Salt regeneration level ( lb salt/ $\mathrm{ft} 3$ resin):

Nitrate Leakage as \% of Influent Nitrate Level $30 \%$

Nitrate Leakage (ppm as NO3):

6.84

Step 3 - Base Nitrate Capacity

Read from Figure \#4

Base Capacity (grains/ Ft3 NO3 (as CaCO3): 5000

\section{Step 4 - Predicted Run Length}

Actual Run Length $=($ Throughput $) /(100 \%-\%$ leakage $) / 100$

Throughput $=($ Base Nitrate Capacity $) /($ Influent Load $)$

Predicted Run Length $(\mathrm{gal} / \mathrm{ft} 3)=\quad 3,658$

Predicted Run Length (gal)

Predicted Run Length (liter)

9,144 based on flow to one column 34,622 


\section{Using Spiking Prediction Values}

\begin{tabular}{|l|c|c|c|}
\hline \multicolumn{1}{|c|}{ Other } & $\mathrm{ppm}^{*}$ & Conversion & $\mathrm{ppm}, \mathrm{CaCO}$ \\
\hline Contaminants & & Factor & \\
\hline Bicarbonate, $\mathrm{H}$ & 370 & 0.82 & 303.4 \\
\hline Sulfate, $\mathrm{SO} 4$ & 53 & 1.04 & 55.12 \\
\hline Chloride, $\mathrm{Cl}$ & 79 & 1.41 & 111.39 \\
\hline
\end{tabular}

* Taken from Genmin analysis run on 12/18/98 (TF-834-EFLU-B111-1300)

\begin{tabular}{|c|c|l|l|l|}
\hline Run \# & Nitrate Conc & Conversion & ppm, CaCO3 & grains/gal \\
\hline & (as NO3) ppm & Factor & & (as CaCO3) \\
\hline 1 & 80.91 & 0.81 & 65.54 & 3.83 \\
\hline & & & & \\
\hline & & & & \\
\hline
\end{tabular}

Step 1 - Percent Nitrate

Percent Nitrate $=(\mathrm{NO} 3 \mathrm{ppm}$ as $\mathrm{CaCO} 3) /(\mathrm{NO} 3 \mathrm{ppm}$ as $\mathrm{CaCO} 3+\mathrm{SO} 4 \mathrm{ppm}$ as $\mathrm{CaCO} 3)$

$\%$ NO3 $=\quad 0.54$

Step 2 - Nitrate Leakage

Read from Figure \#3 in Sybron literature (pg 3)

Salt regeneration level (lb salt/ $\mathrm{ft} 3$ resin):

Nitrate Leakage as \% of Influent Nitrate Level

Nitrate Leakage (ppm as NO3):

Step 3 - Base Nitrate Capacity

Read from Figure \#4

Base Capacity (grains/ Ft3 NO3 (as $\mathrm{CaCO} 3$ ):

5900

\section{Step 4 - Predicted Run Length}

Actual Run Length $=($ Throughput $) /(100 \%-\%$ leakage $) / 100$

Throughput $=($ Base Nitrate Capacity $) /($ Influent Load $)$

Predicted Run Length (gal/ft3)

Predicted Run Length (gal)

Predicted Run Length (liter)
2,140

5,351 based on flow to one column 20,260 
TRIAL A - Regeneration Data Sheets

Regen\#1 - aborted due to low flow rates of brine solutiol

Initial Totalizer Reading 39474

Time $\quad 9: 45$

Final Totalizer Reading:

\begin{tabular}{|c|c|c|c|c|c|c|c|c|}
\hline & $\begin{array}{c}\text { Time } \\
\text { (on PLC) } \\
\text { minutes }\end{array}$ & $\begin{array}{l}\text { Length of } \\
\text { Cycle } \\
\text { minutes }\end{array}$ & $\begin{array}{c}\text { Nitrate } \\
\mathrm{mg} / \mathrm{L} \\
\text { (as NO3) }\end{array}$ & $\begin{array}{c}\text { Chloride } \\
\mathrm{mg} / \mathrm{L}\end{array}$ & $\mathrm{pH}$ & $\begin{array}{c}\text { Flow Rate } \\
\text { Ipm }\end{array}$ & $\begin{array}{l}\text { Flow } \\
\text { gpm }\end{array}$ & $\begin{array}{c}\text { Total Flow } \\
\text { liter }\end{array}$ \\
\hline Backwash Cycle & 8 & 10 & & & & & & \\
\hline & 4 & & & & & & & \\
\hline Brine Draw & 51 & 56 & & & & 1.2 & 0.32 & \\
\hline / Slow Rinse & 46 & & & & & 1.15 & 0.30 & \\
\hline & 36 & & & & & & & \\
\hline & 26 & & & & & & & \\
\hline & 16 & & & & & & & \\
\hline & 6 & & & & & & & \\
\hline Rapid Rinse & 3 & 6 & & & & 4.35 & 1.15 & \\
\hline Brine Tank Fill & & 36 & & & & & & \\
\hline
\end{tabular}

Initial Brine tank level (in):

Final brine tank level (in):

14

Volume dispensed (gal):

35.76 


\section{Regen\#2 - Using Hach Kit data}

Initial Totalizer Reading (I) $\quad 57890$

Time 9:45

Initial Pressure (psi)

Initial Brine tank level (in): $\quad 14$

Salt (in):

Final Brine tank level:

Final Totalizer reading:

New brine tank level:

3.3

Feed nitrate concentration:

58421

26
37.5

\begin{tabular}{|c|c|c|c|c|c|c|c|c|c|c|c|}
\hline & $\begin{array}{c}\text { Time } \\
\text { (on PLC) } \\
\text { minutes } \\
\end{array}$ & $\begin{array}{l}\text { Length of } \\
\text { Cycle } \\
\text { minutes }\end{array}$ & $\begin{array}{c}\text { Nitrate } \\
\mathrm{mg} / \mathrm{L} \\
\text { (as NO3) }\end{array}$ & $\begin{array}{c}\text { orrect Nitrat } \\
\text { Levels } \\
\text { mg/ I NO3 } \\
\end{array}$ & $\begin{array}{c}\text { Chloride } \\
\mathrm{mg} / \mathrm{L}\end{array}$ & $\begin{array}{l}\text { Corrected } \\
\text { Chloride } \\
\text { levels (\%) }\end{array}$ & $\mathrm{pH}$ & $\begin{array}{c}\text { Flow Rate } \\
\text { Ipm }\end{array}$ & $\begin{array}{c}\text { Flow rate } \\
\text { gpm }\end{array}$ & $\begin{array}{c}\text { Total Flow } \\
\text { gal }\end{array}$ & $\begin{array}{c}\text { Pressure } \\
\text { psi }\end{array}$ \\
\hline \multirow[t]{2}{*}{ Backwash Cycle } & 8 & 10 & 49.1 & \begin{tabular}{|l|}
47.87 \\
\end{tabular} & 1 & $0.10 \%$ & 6.73 & 6.3 & 1.66 & 16.64 & 30 \\
\hline & 4 & & 35.9 & 34.67 & 1 & $0.10 \%$ & 6.79 & & 0 & & \\
\hline Brine Draw & 51 & 56 & 63.1 & 62 & 1 & $0.10 \%$ & 6.81 & 2.63 & 0.69 & & 35 \\
\hline \multirow{5}{*}{ / Slow Rinse } & 46 & & 56.1 & 55 & 1 & $0.10 \%$ & 6.81 & 2.70 & 0.71 & & \\
\hline & 36 & & 4320 & 4295 & 20 & $2.00 \%$ & 8.38 & 3.00 & 0.79 & & \\
\hline & 26 & & 24700 & 24636 & 52 & $5.20 \%$ & 8.15 & 2.70 & 0.71 & & \\
\hline & 16 & & 17540 & 17456 & 68 & $6.80 \%$ & 8.18 & & & & \\
\hline & 6 & & 15240 & 15149 & 74 & $7.40 \%$ & 8.18 & & & 40.77 & \\
\hline Rapid Rinse & 3 & 6 & 10900 & 10807 & 76 & $7.60 \%$ & 8.02 & 6.3 & 1.66 & 9.98 & 30 \\
\hline \multirow[t]{2}{*}{ Brine Tank Fill } & & 36 & & & & & & & & & 32 \\
\hline & & & & & & & & & Total: & 67.39 & gallons \\
\hline Next time: get & for salinit & ding.... & & & & & & & & & \\
\hline
\end{tabular}




\section{Trial A - Regeneration Data}

Hach kit data

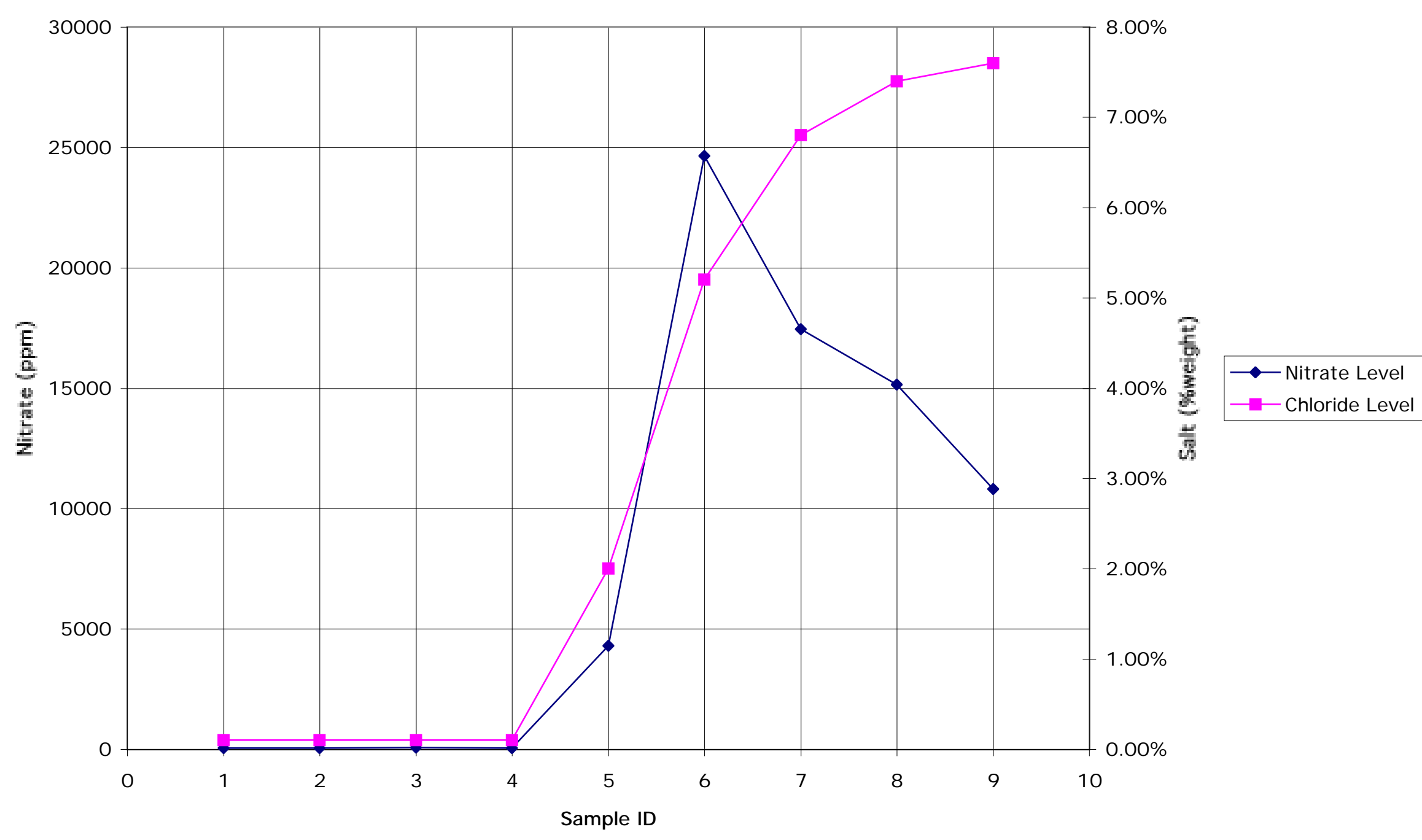




\begin{tabular}{|c|c|c|c|c|c|c|c|c|}
\hline \multicolumn{9}{|c|}{ TRIAL A - Regeneration Analysis } \\
\hline \multicolumn{9}{|l|}{ Regen\#2 } \\
\hline Initial Totalizer Reading (I) & 57890 & & & & & & & \\
\hline Time & 9:45 & & & & & & & \\
\hline Initial Pressure (psi) & 35 & & & & & & & \\
\hline Initial Brine tank level (in): & 14 & & & & & & & \\
\hline Level w/ Salt (in): & 18.5 & & & & & & & \\
\hline Final Brine tank level: & 3.3 & & & & & & & \\
\hline Final Totalizer reading: & 58421 & & & & & & & \\
\hline New brine tank level: & 26 & & & & & & & \\
\hline \multirow{2}{*}{ Feed nitrate concentration: } & 37.5 & & & & & & & \\
\hline & $\begin{array}{c}\text { Sample } \\
\text { Time } \\
\end{array}$ & $\begin{array}{c}\text { Correct Nitrat } \\
\text { Levels } \\
\mathrm{mg} / \mathrm{I} \mathrm{NO} 3\end{array}$ & $\begin{array}{l}\text { Corrected } \\
\text { Chloride } \\
\text { levels (\%) }\end{array}$ & $\mathrm{pH}$ & $\begin{array}{c}\text { Flow Rate } \\
\text { Ipm }\end{array}$ & $\begin{array}{c}\text { Flow rate } \\
\text { gpm }\end{array}$ & $\begin{array}{c}\text { otal Flo } \\
\text { gal }\end{array}$ & $\begin{array}{c}\text { Pressure } \\
\text { psi }\end{array}$ \\
\hline \multirow[t]{2}{*}{ Backwash Cycle } & BW4 & 47.87 & $0.10 \%$ & 6.73 & 6.3 & 1.66 & 16.64 & 30 \\
\hline & BW8 & 34.67 & $0.10 \%$ & 6.79 & & 0 & & \\
\hline Brine Draw & 5 & 62 & $0.10 \%$ & 6.81 & 2.63 & 0.69 & & 35 \\
\hline \multirow[t]{5}{*}{ / Slow Rinse } & 10 & 55 & $0.10 \%$ & 6.81 & 2.70 & 0.71 & & \\
\hline & 20 & 4295 & $2.00 \%$ & 8.38 & 3.00 & 0.79 & & \\
\hline & 30 & 24636 & $5.20 \%$ & 8.15 & 2.70 & 0.71 & & \\
\hline & 40 & 17456 & $6.80 \%$ & 8.18 & & & & \\
\hline & 50 & 15149 & $7.40 \%$ & 8.18 & & & 40.77 & \\
\hline Rapid Rinse & 59 & 10807 & $7.60 \%$ & 8.02 & 6.3 & 1.66 & 9.98 & 30 \\
\hline \multirow[t]{2}{*}{ Brine Tank Fill } & & & & & & & & 32 \\
\hline & & & & & & Total: & 67.39 & gallons \\
\hline & & & & & & & & \\
\hline
\end{tabular}




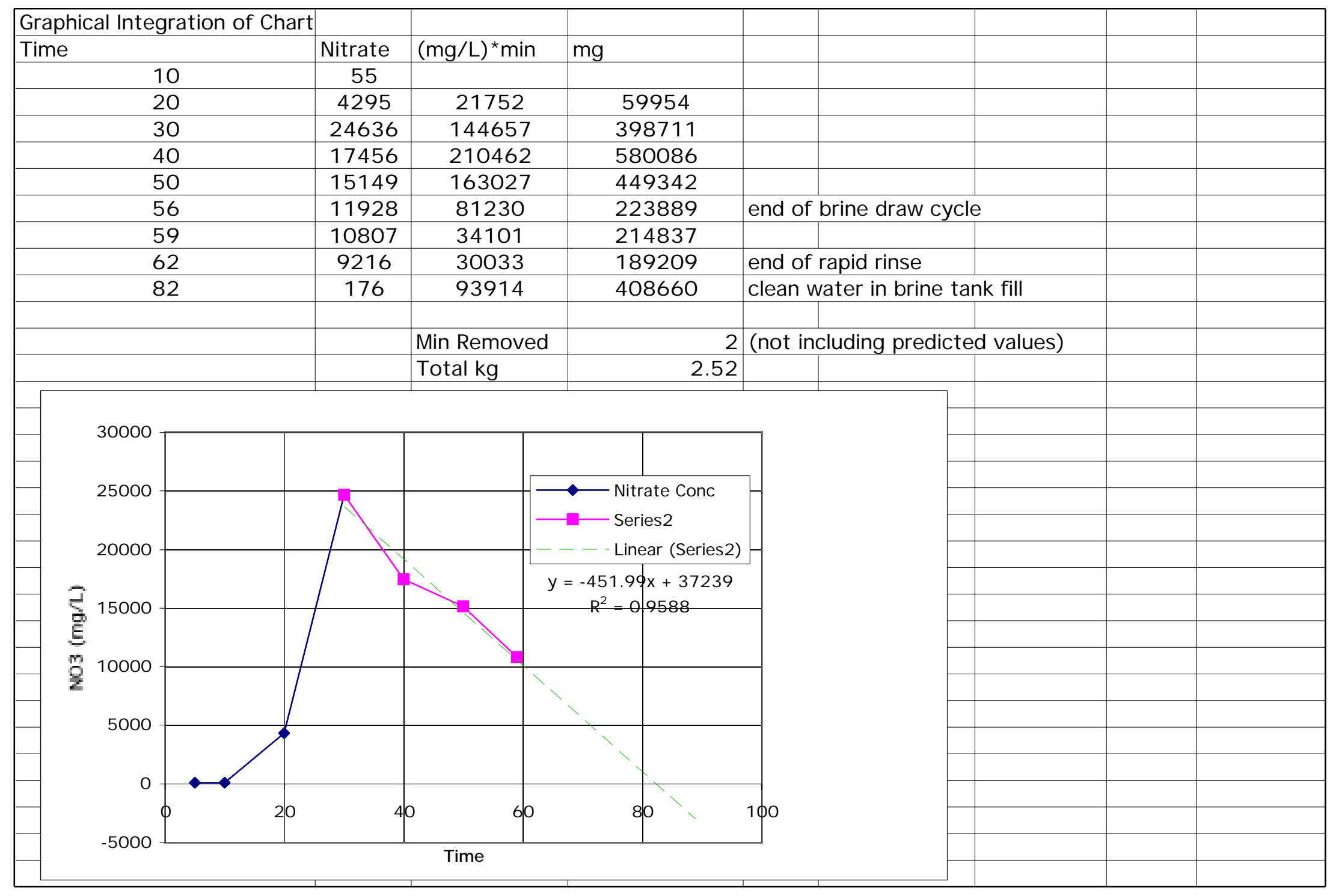


Trial B Data 

TRIAL B - Raw Data

\begin{tabular}{|c|c|c|c|c|c|c|c|c|c|c|}
\hline Date & $\begin{array}{c}\text { Time } \\
\text { (on PLC) }\end{array}$ & $\begin{array}{c}\text { Total Flow } \\
\text { Reading } \\
\text { liters }\end{array}$ & $\begin{array}{l}\text { Flow } \\
\text { Rate } \\
\text { Ipm }\end{array}$ & SAMPLE ID & $\begin{array}{c}\text { Logbook } \\
\text { ID \# }\end{array}$ & \multicolumn{2}{|c|}{\begin{tabular}{|l|} 
Influent \\
Nitrate $(\mathrm{mg} / \mathrm{L})$
\end{tabular}} & \multicolumn{2}{|c|}{\begin{tabular}{|l} 
Effluent \\
Nitrate $(\mathrm{mg} / \mathrm{L})$
\end{tabular}} & Notes \\
\hline $4 / 9 / 99$ & $10: 45$ & 58500 & & & & & & & & Added $575 \mathrm{~g} \mathrm{NaNO} 3$ to $6300 \mathrm{~L}$ \\
\hline & $10: 54$ & 58545 & 30 & & & & 73.5 & & 26.8 & \\
\hline & $12: 33$ & 61226 & 31 & & & & 70.2 & & 19.7 & \\
\hline & $13: 55$ & 64033 & 30.7 & 3X046-OPTB-64033-I/E & ZB149 & 119 & 77.7 & 16 & 19.6 & \\
\hline \multirow[t]{4}{*}{$4 / 14 / 99$} & $8: 50$ & 64033 & 31 & & & & & & & Added $300 \mathrm{~g} \mathrm{NaNO} 3$ to $4200 \mathrm{~L}$ \\
\hline & $10: 30$ & 64179 & & 3X046-OPTB-64179-1/E & ZB149 & 97 & 57.7 & 18 & 12.5 & \\
\hline & $10: 14$ & 66583 & 30 & 3X046-OPTB-66583-1/E & ZB150 & 95 & & 57 & & \\
\hline & $11: 12$ & 68726 & 29.9 & 3X046-OPTB-68726-I/E & ZB151 & 95 & & 19 & & \\
\hline \multirow[t]{5}{*}{$4 / 19 / 99$} & $9: 28$ & 68750 & 29.8 & & & & & & & Added $500 \mathrm{~g} \mathrm{NaNO} 3$ to $6900 \mathrm{~L}$ \\
\hline & $10: 32$ & 70662 & & & & & & & & \\
\hline & $11: 39$ & 72687 & 29.9 & 3X046-B-72687-I/E & ZB154 & 102 & 75.8 & 51 & 51.3 & \\
\hline & $12: 23$ & 73974 & & 3X046-B-73976-I/E & ZB154 & 105 & 61.4 & 74 & 49.5 & \\
\hline & $12: 51$ & 74807 & & 3X046-B-74807-I/E & ZB154 & 103 & & 86 & & \\
\hline \multirow[t]{2}{*}{$4 / 29 / 99$} & $11: 40$ & 76778 & 30.7 & 3X046-B-76778-I/E & ZB155 & 77 & 53.4 & 80 & 51.1 & Added $570 \mathrm{~g} \mathrm{NaNO3}$ to $7550 \mathrm{~L}$ \\
\hline & 13:00 & 79144 & & 3X046-B-79144-I/E & ZB155 & 77 & 48.5 & 84 & 48.3 & \\
\hline
\end{tabular}


TRIAL B - Breakthrough Curve Data

Unit run at $7.5 \mathrm{gpm}$ (one column mode)

All samples analyzed by BC labs

\begin{tabular}{|r|c|c|c|c|c|c|c|c|c|}
\cline { 2 - 10 } & $\begin{array}{l}\text { Flow Meter } \\
\text { Reading } \\
\text { (liters) }\end{array}$ & $\begin{array}{c}\text { Total } \\
\text { Flow } \\
\text { (liters) }\end{array}$ & $\begin{array}{c}\text { Total } \\
\text { Flow } \\
\text { (gallons) }\end{array}$ & $\begin{array}{c}\text { Influent } \\
\text { NO3 Conc } \\
(\mathrm{mg} / \mathrm{L})\end{array}$ & $\begin{array}{c}\text { Effluent } \\
\text { NO3 Conc } \\
(\mathrm{mg} / \mathrm{L})\end{array}$ & $\begin{array}{c}\text { Influent } \\
\text { NO3 amount } \\
(\mathrm{g})\end{array}$ & $\begin{array}{c}\text { Effluent } \\
\text { NO3 Amount } \\
(\mathrm{g})\end{array}$ & $\begin{array}{c}\text { Nitrate } \\
\text { Removed } \\
(\mathrm{g})\end{array}$ & $\begin{array}{c}\text { Removal } \\
\text { Efficiency }\end{array}$ \\
\hline $4 / 9 / 99$ & 64033 & 5533 & 1461 & 119.0 & 16.0 & 658.4 & 88.5 & 569.9 & $86.6 \%$ \\
\hline $4 / 14 / 99$ & 64179 & 5679 & 1500 & 97.0 & 18.0 & 15.8 & 2.5 & 13.3 & $84.3 \%$ \\
\hline & 68726 & 10226 & 2701 & 95.0 & 19.0 & 436.5 & 84.1 & 352.4 & $80.7 \%$ \\
\hline $4 / 19 / 99$ & 72687 & 14187 & 3747 & 102.0 & 51.0 & 390.2 & 138.6 & 251.5 & $64.5 \%$ \\
\hline & 73974 & 15474 & 4087 & 105.0 & 74.0 & 133.2 & 80.4 & 52.8 & $39.6 \%$ \\
\hline & 74807 & 16307 & 4307 & 103.0 & 86.0 & 86.6 & 66.6 & 20.0 & $23.1 \%$ \\
\hline $4 / 29 / 99$ & 76778 & 18278 & 4827 & 77.0 & 80.0 & 177.4 & 163.6 & 13.8 & $7.8 \%$ \\
\hline & 79144 & 20644 & 5452 & 77.0 & 84.0 & 182.2 & 194.0 & -11.8 & $-6.5 \%$ \\
\hline
\end{tabular}

Weighted Average Effluent Concentration (before breakthrough

Weighted Average Effluent Concentration (overall):

17.13

39.65

Weighted Average Removal Efficiency (before breakthrough): $\quad$ 83.9\%

Liters Treated (overall):

Liters Treated (before breakthrough):

20644

Gallons Treated (overall):

10226

Gallons Treated (before breakthrough):

4827

Total Nitrate Removed ( $\mathrm{kg}$ ):

2701

$\%$ of water treated when breakthrough began:

$55.9 \%$

New water treated/ waste ratio w/ regeneration modification $\quad 58.7$ 
Trial B - Breakthrough Chart

$7.5 \mathrm{gpm}$, one column operation

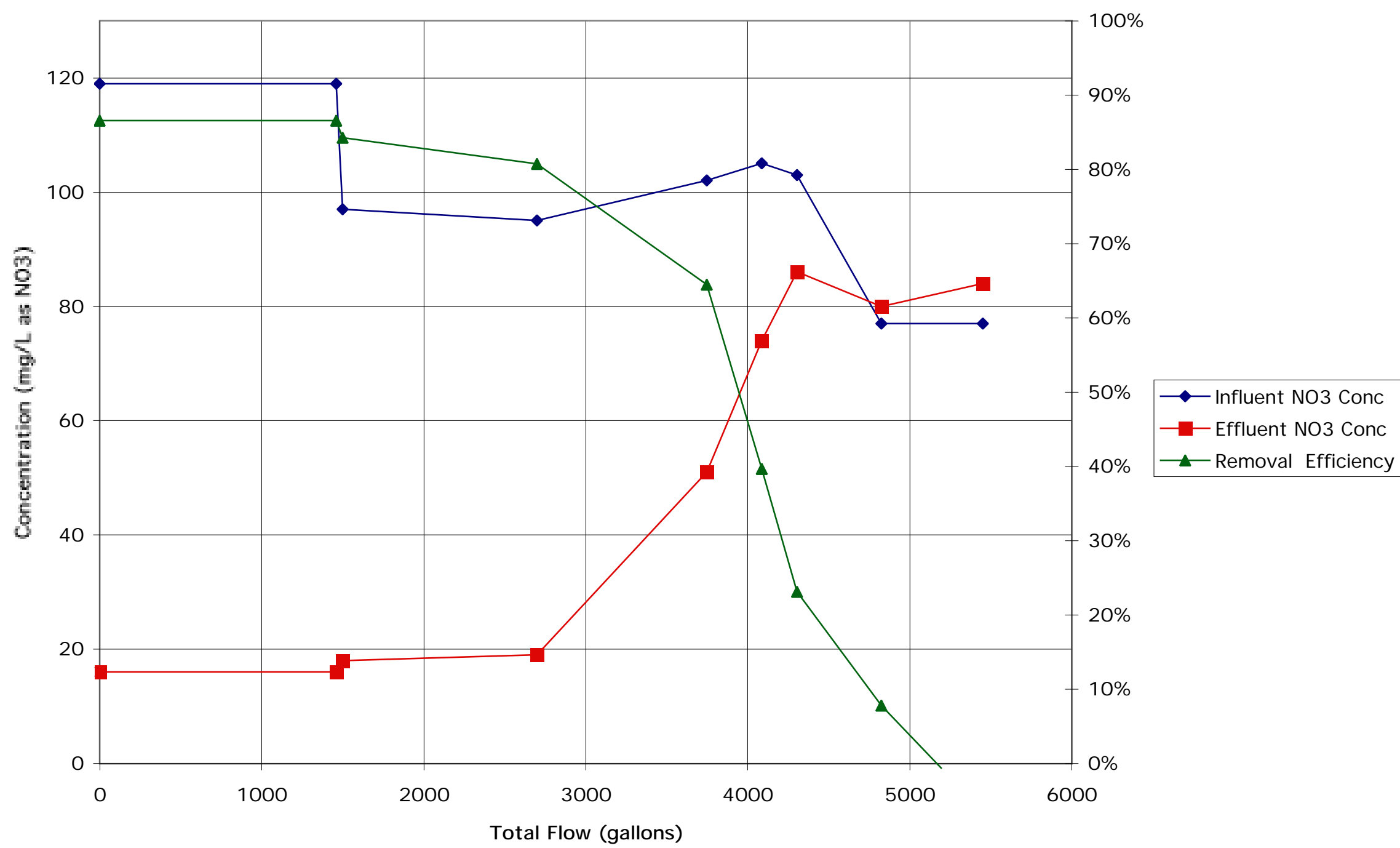




\section{TRIAL B - Breakthrough Predictions}

based on Sybron Literature predictions, see Appendix F For sample calcs

\begin{tabular}{|l|c|c|c|}
\hline \multicolumn{1}{|c|}{ Other } & ppm* & Conversion & ppm, CaCO3 \\
\hline Contaminants & & Factor & \\
\hline Bicarbonate, $\mathrm{HCO} 3$ & 370 & 0.82 & 303.4 \\
\hline Sulfate, SO4 & 70 & 1.04 & 72.8 \\
\hline Chloride, Cl & 79 & 1.41 & 111.39 \\
\hline
\end{tabular}

* Taken from Genmin analysis run on 12/18/98 (TF-834-EFLU-B111-1300), A24778

\begin{tabular}{|c|c|c|c|c|}
\hline Trial \# & Nitrate Conc & Conversion & $\mathrm{ppm}, \mathrm{CaCO} 3$ & grains/gal \\
\hline & (as NO3) ppm & Factor & & (as CaCO3) \\
\hline B & 100.77 & 0.81 & 81.62 & 4.77 \\
\hline
\end{tabular}

Step 1 - Percent Nitrate

Percent Nitrate $=(\mathrm{NO} 3 \mathrm{ppm}$ as $\mathrm{CaCO} 3) /(\mathrm{NO} 3 \mathrm{ppm}$ as $\mathrm{CaCO} 3+\mathrm{SO} 4 \mathrm{ppm}$ as $\mathrm{CaCO} 3)$

$\% \mathrm{NO3}=\quad 53 \%$

Step 2 - Nitrate Leakage

Figure \#3 in Sybron literature (pg 3)

Salt regeneration level (lb salt/ft3 resin): 10

Nitrate Leakage as \% of Influent Nitrate Level $\quad 27 \%$

Nitrate Leakage (ppm as NO3): $\quad 33.59$

Step 3 - Base Nitrate Capacity

Read from Figure \#4

Base Capacity (grains/ft3 (NO3 as CaCO3)) 6000

Step 4 - Predicted Run Length

Actual Run Length $=($ Throughput $) /(100 \%-\%$ leakage $) / 100$

Throughput $=($ Base Capacity $) /($ Influent Load)

Predicted Run Length (gal/ ft3) $=$

Predicted Run Length (gal)

Predicted Run Length (liter)
1,724

4,309 Based on flow to only one column

16,311 Based on flow to only one column

\section{Comparison with actual Data:}

$\%$ of actual gallons treated: $\quad 79.0 \%$

$\%$ of actual leakage rate: $\quad 196.1 \%$ 
TRIAL B - Regeneration Data Sheets

all data analyzed by BC labs, ZB156

Initial Totalizer Reading (I)

Initial Pressure ( $p s i)$

Level w/ Salt (in):

Final Tre tank

Feed nitrate concentration

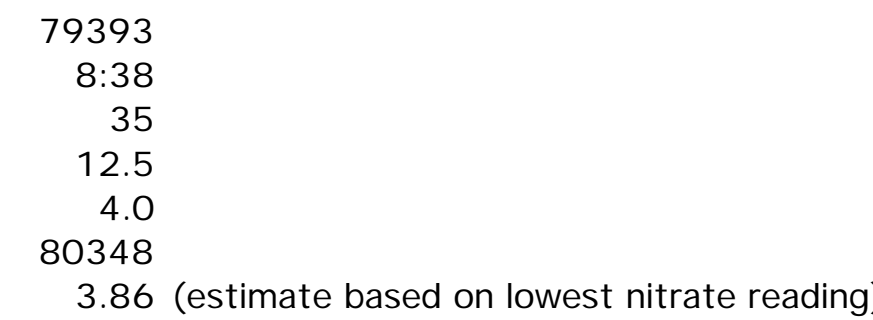

\begin{tabular}{|c|c|c|c|c|}
\hline & $\begin{array}{c}\text { Time } \\
\text { (from start) } \\
\text { minutes } \\
\end{array}$ & $\begin{array}{c}\text { Time } \\
\text { (on PLC) } \\
\text { minutes } \\
\end{array}$ & $\begin{array}{c}\text { Time } \\
\text { from start } \\
\text { of regen cycle }\end{array}$ & $\begin{array}{l}\text { Length of } \\
\text { Cycle } \\
\text { minutes }\end{array}$ \\
\hline \multirow[t]{2}{*}{ Backwash Cycle } & 4 & 6 & 4 & 10 \\
\hline & 8 & 2 & 8 & \\
\hline Brine Draw & 5 & 195 & 15 & 200 \\
\hline \multirow[t]{11}{*}{ /Slow Rinse } & 10 & 190 & 20 & \\
\hline & 15 & 185 & 25 & \\
\hline & 20 & 180 & 30 & \\
\hline & 25 & 175 & 35 & \\
\hline & 30 & 170 & 40 & \\
\hline & 35 & 165 & 45 & \\
\hline & 40 & 160 & 50 & \\
\hline & 45 & 155 & 55 & \\
\hline & 50 & 150 & 60 & \\
\hline & 55 & 145 & 65 & \\
\hline & 60 & 140 & 70 & \\
\hline \multirow[t]{2}{*}{ Rapid Rinse } & 2 & 4 & $\overline{72}$ & 6 \\
\hline & 4 & 2 & 76 & \\
\hline \multirow{2}{*}{ Brine Tank Fill } & 6 & 10 & 82 & 20 \\
\hline & 16 & 20 & 98 & \\
\hline
\end{tabular}

\begin{tabular}{|l|c|} 
& psi \\
\hline LX167-OPTB-BW-6 & 35 \\
\hline LX167-OPTB-BW-2 & \\
\hline LX167-OPTB-BDSR-195 & 30 \\
\hline LX167-OPTB-BDSR-190 & \\
\hline LX167-OPTB-BDSR-185 & \\
\hline LX167-OPTB-BDSR-180 & \\
\hline LX167-OPTB-BDSR-175 & \\
\hline LX167-OPTB-BDSR-170 & \\
\hline LX167-OPTB-BDSR-165 & \\
\hline LX167-OPTB-BDSR-160 & \\
\hline LX167-OPTB-BDSR-155 & \\
\hline LX167-OPTB-BDS-150 & \\
\hline LX167-OPTB-BDS-145 & 35 \\
\hline LX167-OPTB-BDSR-140 & \\
\hline LX167-OPTB-RR-4 & \\
\hline LX167-OPTB-RR-2 & \\
\hline LX167-OPTB-BTF-10 & \\
\hline LX167-OPTB-BTF-20 & \\
\hline
\end{tabular}

Nitrate

\begin{tabular}{|c|c|c|c|c|}
\hline $\begin{array}{c}\text { Flow Rate } \\
\text { Ipm }\end{array}$ & $\begin{array}{l}\text { Total Nitrate } \\
\text { grams }\end{array}$ & $\begin{array}{c}\text { Total Chloride } \\
\text { grams }\end{array}$ & Total Flow & $\begin{array}{c}\text { Total Flow } \\
\text { gal }\end{array}$ \\
\hline 6 & 1536 & 1080 & 24.00 & 6.34 \\
\hline 6 & 2484 & 1476 & 36.00 & 9.51 \\
\hline 2.78 & 2220 & 1221 & 27.75 & 7.33 \\
\hline & & & & \\
\hline 2.93 & 182258 & 436691 & 42.75 & 11.29 \\
\hline & & & & \\
\hline 2.63 & 394975 & 990675 & 27.75 & 7.33 \\
\hline 2.63 & 201469 & 539438 & 13.13 & 3.47 \\
\hline & & & & \\
\hline & & & & \\
\hline 2.55 & 530955 & 1966500 & 51.75 & 13.67 \\
\hline 6.45 & & & & \\
\hline & 4489 & 25929 & 38.70 & 10.22 \\
\hline 0.65 & & & 13.00 & 3.43 \\
\hline & & & & \\
\hline
\end{tabular}

Nitrate removed $(\mathrm{kg})$ :

1.316

3.963

$\begin{array}{lcccc}\begin{array}{l}\text { Chloride } \\ (\mathrm{mg} / \mathrm{L})\end{array} & \begin{array}{c}\text { Nitrate } \\ (\mathrm{mg} / \mathrm{L})\end{array} & \begin{array}{c}\text { Waste Drum } \\ \text { Volume }(\text { gal })\end{array} & \text { Liters } & \text { Nitrate removed }(\mathrm{kg}) \\ 15500 & 5090 & 55 & 208.24 & 1.06 \\ 10900 & 1820 & 14.87 & 56.30 & 0.10 \\ & & & & 1.16\end{array}$

Summary

Gallons waste produced:

kg Nitrate removed:

69.15

Regen removal efficiency:

1.32

Gallons waste produced

$103.4 \%$

Drum \#2 Sample LX167-OPTB-DRUM2

0.72

Reduction in waste \%

46.0
$33.5 \%$ 
Trial B - Regeneration

BC labs data, using food grade salt

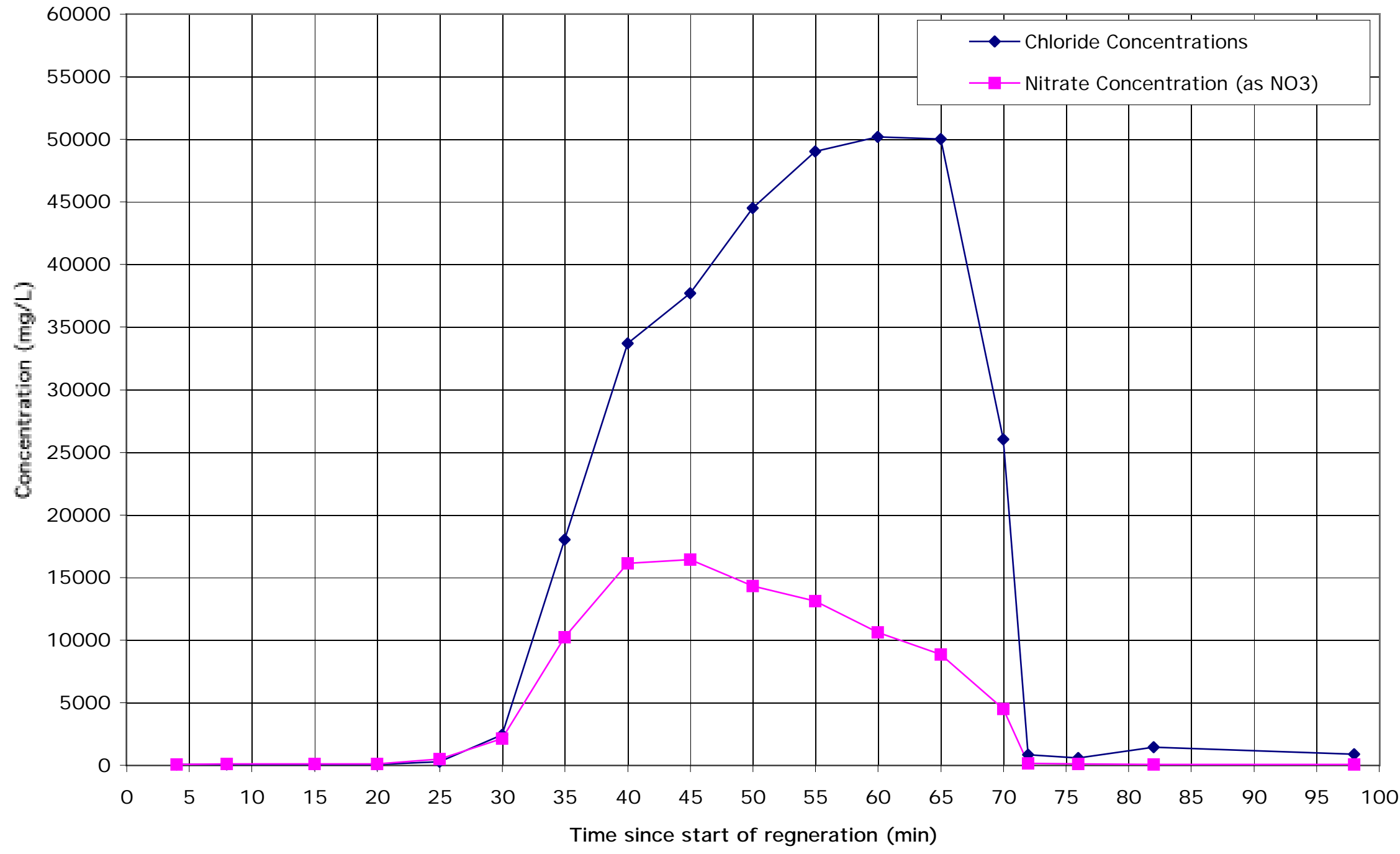


Trial C Data 

TRIAL C - Raw Data

Data from BC labs

\begin{tabular}{|c|c|c|c|c|c|c|c|c|}
\hline \multirow[t]{2}{*}{ Date } & \multirow{2}{*}{$\begin{array}{c}\text { Time } \\
\text { (on PLC) }\end{array}$} & \multirow{2}{*}{$\begin{array}{l}\text { Total Flow } \\
\text { Reading } \\
\text { liters }\end{array}$} & \multirow{2}{*}{$\begin{array}{l}\text { Flow } \\
\text { Rate } \\
\text { Ipm }\end{array}$} & \multirow[t]{2}{*}{ SAMPLE ID } & \multirow{2}{*}{$\begin{array}{c}\text { Logbook } \\
\text { ID \# }\end{array}$} & \multirow{2}{*}{\begin{tabular}{|c} 
Influent \\
Nitrate \\
$(\mathrm{mg} / \mathrm{L})$ \\
\end{tabular}} & \multirow{2}{*}{\begin{tabular}{|c|} 
Effluent \\
Nitrate \\
(mg/ L)
\end{tabular}} & \multirow[t]{2}{*}{ Notes } \\
\hline & & & & & & & & \\
\hline \multirow[t]{3}{*}{$5 / 13 / 99$} & $8: 48$ & 80405 & 29.8 & & & & & \\
\hline & 9:55 & 82366 & 28.8 & $3 \times 046-O P T C-82366$ & ZB159 & 107 & 27 & \\
\hline & $11: 35$ & 85288 & 28.7 & 3X046-OPTC-82528 & ZB159 & 110 & 20 & \\
\hline \multirow[t]{3}{*}{$5 / 18 / 99$} & $8: 27$ & 87005 & 29.3 & & & & & Level $42 "$, spiked with $900 \mathrm{ml}$ of $500 \mathrm{~g} / \mathrm{ml} \mathrm{NaNO3}$ \\
\hline & 9:07 & 88180 & 29.5 & $3 \times 046-C-88180$ & ZB160 & 99 & 20 & Sample time: $10: 30 \mathrm{am}$ \\
\hline & $10: 37$ & 90801 & 29.5 & $3 \times 046-C-90801$ & ZB160 & 102 & 24 & \\
\hline \multirow[t]{4}{*}{$5 / 24 / 99$} & 9:05 & 91780 & 29.9 & & & & & Level 62", spiked with 500 grams NaNO3 \\
\hline & $10: 28$ & 94192 & 29.7 & $3 \times 046-O P T C-94192$ & ZB150 & 96 & 22 & \\
\hline & $12: 02$ & 96943 & 29.2 & $3 \times 046-O P T C-96943$ & ZB150 & 98 & 52 & \\
\hline & $12: 55$ & 98461 & 28.9 & $3 \times 046-O P T C-98461$ & ZB150 & 97 & 77 & \\
\hline \multirow[t]{4}{*}{$5 / 25 / 99$} & $8: 43$ & 98505 & 29.9 & & & & & Level 42", spiked with 376 grams NaNO3 \\
\hline & $9: 34$ & 100028 & 29.8 & 3X046-OPTC-100028 & ZB151 & 85 & 100 & \\
\hline & $10: 33$ & 101776 & 29.9 & 3X046-OPTC-98461 & ZB151 & 88 & 105 & \\
\hline & & & & & & & & \\
\hline
\end{tabular}


TRIAL C - Breakthrough Curve Data

Unit run at $7.5 \mathrm{gpm}$ (one column mode)

All samples analyzed by BC labs

\begin{tabular}{|c|c|c|c|c|c|c|c|c|c|}
\cline { 2 - 10 } & $\begin{array}{c}\text { Flow Meter } \\
\text { Reading } \\
\text { (liters) }\end{array}$ & $\begin{array}{c}\text { Total } \\
\text { Flow } \\
\text { (liters) }\end{array}$ & $\begin{array}{c}\text { Total } \\
\text { Flow } \\
\text { (gallons) }\end{array}$ & $\begin{array}{c}\text { Influent } \\
\text { NO3 Conc } \\
(\mathrm{mg} / \mathrm{L})\end{array}$ & $\begin{array}{c}\text { Effluent } \\
\text { NO3 Conc } \\
(\mathrm{mg} / \mathrm{L})\end{array}$ & $\begin{array}{c}\text { Influent } \\
\text { NO3 amount } \\
(\mathrm{g})\end{array}$ & $\begin{array}{c}\text { Effluent } \\
\text { NO3 Amount } \\
(\mathrm{g})\end{array}$ & $\begin{array}{c}\text { Nitrate } \\
\text { Removed } \\
(\mathrm{g})\end{array}$ & $\begin{array}{c}\text { Removal } \\
\text { Efficiency }\end{array}$ \\
\hline $5 / 3 / 99$ & 82366 & 1961 & 518 & 107.0 & 27.0 & 209.8 & 52.9 & 156.9 & $74.8 \%$ \\
\hline & 85288 & 6600 & 1743 & 110.0 & 20.0 & 503.3 & 109.0 & 394.3 & $78.3 \%$ \\
\hline $5 / 17 / 99$ & 88180 & 7775 & 2053 & 99.0 & 20.0 & 122.8 & 23.5 & 99.3 & $80.9 \%$ \\
\hline & 90801 & 10396 & 2746 & 102.0 & 24.0 & 263.4 & 57.7 & 205.7 & $78.1 \%$ \\
\hline $5 / 24 / 99$ & 94192 & 13787 & 3641 & 96.0 & 22.0 & 335.7 & 78.0 & 257.7 & $76.8 \%$ \\
\hline & 96943 & 16538 & 4368 & 98.0 & 52.0 & 266.8 & 101.8 & 165.1 & $61.9 \%$ \\
\hline & 98461 & 18056 & 4769 & 97.0 & 77.0 & 148.0 & 97.9 & 50.1 & $33.8 \%$ \\
\hline $5 / 25 / 99$ & 100028 & 19579 & 5171 & 85.0 & 100.0 & 138.6 & 134.8 & 3.8 & $2.7 \%$ \\
\hline & 101776 & 21327 & 5633 & 85.0 & 105.0 & 148.6 & 179.2 & -30.6 & $-20.6 \%$ \\
\hline
\end{tabular}

Weighted Average Effluent Concentration (before breakthrough $\quad 23.29$

Weighted Average Effluent Concentration (overall):

33.48

Weighted Average Removal Efficiency (before breakthrough):

$77.6 \%$

Liters Treated (overall):

Liters Treated (before breakthrough):

19579

Gallons Treated (overall):

13787

Gallons Treated (before breakthrough):

5171

Total Nitrate Removed $(\mathrm{kg})$ :

3641

$\%$ of water treated when breakthrough began:

$70.4 \%$

New water treated/ waste ratio $\mathrm{w} /$ regeneration modification $\quad 76.6$ 
Trial C - Breakthrough Chart

$7.5 \mathrm{gpm}$, one column operation

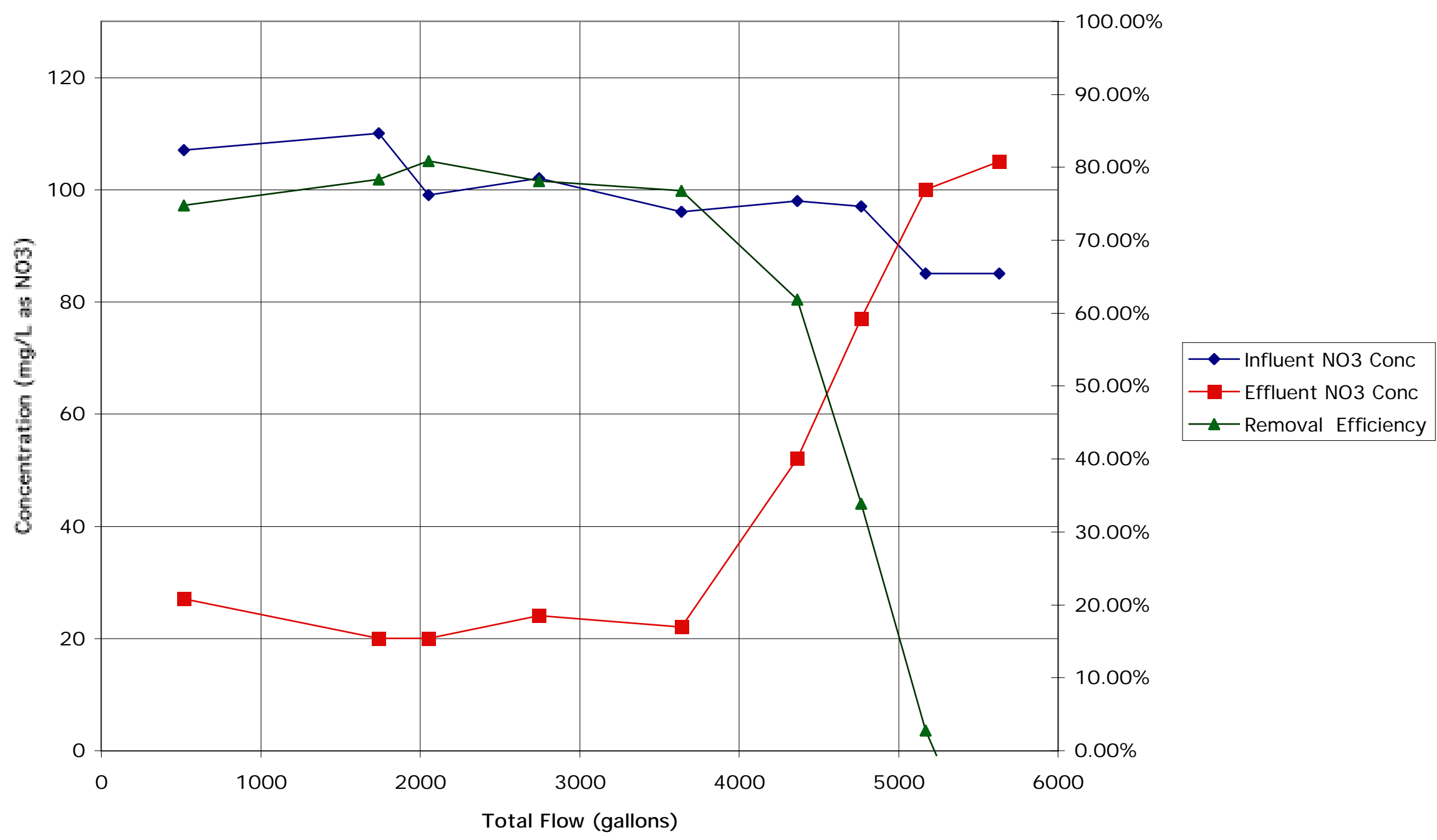




\section{TRIAL C - Breakthrough Predictions}

based on Sybron Literature predictions, see Appendix F For sample calcs

\begin{tabular}{|l|c|c|c|}
\hline \multicolumn{1}{|c|}{ Other } & $\mathrm{ppm}^{*}$ & Conversion & $\mathrm{ppm}, \mathrm{CaCO} 3$ \\
\hline \multicolumn{1}{|c|}{ Contaminants } & & Factor & \\
\hline Bicarbonate, $\mathrm{HCO} 3$ & 370 & 0.82 & 303.4 \\
\hline Sulfate, $\mathrm{SO} 4$ & 70 & 1.04 & 72.8 \\
\hline Chloride, $\mathrm{Cl}$ & 79 & 1.41 & 111.39 \\
\hline
\end{tabular}

* Taken from Genmin analysis run on 12/18/98 (TF-834-EFLU-B111-1300), A2478

\begin{tabular}{|c|l|l|l|l|}
\hline Trial \# & Nitrate Conc & Conversion & ppm, CaCO3 & grains/gal \\
\hline & (as NO3) ppm & Factor & & (as CaCO3) \\
\hline C & 100.21 & 0.81 & 81.17 & 4.74 \\
\hline
\end{tabular}

Step 1 - Percent Nitrate

Percent Nitrate $=(\mathrm{NO} 3 \mathrm{ppm}$ as $\mathrm{CaCO} 3) /(\mathrm{NO} 3 \mathrm{ppm}$ as $\mathrm{CaCO} 3+\mathrm{SO} 4 \mathrm{ppm}$ as $\mathrm{CaCO} 3)$

$\% \mathrm{NO3}=\quad 0.53$

Step 2 - Nitrate Leakage

Read from Figure \#3 in Sybron literature (pg 3)

Salt regeneration level (lb salt/ft3 resin):

Nitrate Leakage as \% of Influent Nitrate Level 27\%

Nitrate Leakage ( $p$ pm as NO3):

Step 3 - Base Nitrate Capacity

Read from Figure \#4

Base Capacity (grains/Ft3 (NO3 as CaCO3)) 6000

Step 4 - Predicted Run Length

Actual Run Length $=($ Throughput $) /(100 \%-\%$ leakage $) / 100$

Throughput $=($ Base Nitrate Capacity $) /($ Influent Lo; Based on flow to one column

Predicted Run Length $(\mathrm{gal} / \mathrm{ft} 3)=\quad 1,733$

Predicted Run Length (gal) 4,334

Predicted Run Length (liter) 16,408

\section{Comparison with actual Data:}

$\%$ of actual gallons treated:

$\%$ of actual leakage rate: 
TRIAL C -Regeneration Data Sheets

all data analyzed by BC labs, ZB152

using Culligan Waster softener salt (solar salt)

Initial Totalizer Reading (I)

Time

Initial Pressure (psi)

Initial Brine tank level (in):

Feed nitrate concentration

Feed chloride conc:

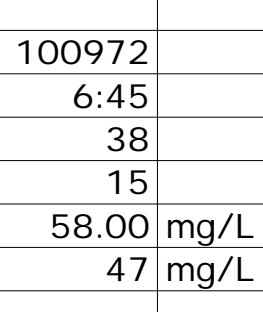

\begin{tabular}{|c|c|c|c|c|c|c|c|c|c|c|c|c|c|}
\hline & $\begin{array}{c}\text { Time } \\
\text { (from start) } \\
\text { minutes } \\
\end{array}$ & $\begin{array}{c}\text { Time } \\
\text { (on PLC) } \\
\text { minutes } \\
\end{array}$ & $\begin{array}{c}\text { Time } \\
\text { from start } \\
\text { of regen cycle }\end{array}$ & $\begin{array}{l}\text { Length of } \\
\text { Cycle } \\
\text { minutes }\end{array}$ & Sample ID & $\begin{array}{c}\text { Pressure } \\
\text { psi }\end{array}$ & $\begin{array}{c}\text { Flow Rate } \\
\text { Ipm }\end{array}$ & $\begin{array}{c}\text { Chloride Level } \\
\mathrm{mg} / \mathrm{L}\end{array}$ & \begin{tabular}{c|} 
Nitrate Level \\
$\mathrm{mg} / \mathrm{L}$ (as NO3)
\end{tabular} & \begin{tabular}{|c|}
$\begin{array}{c}\text { Total Nitrate } \\
\text { grams }\end{array}$ \\
\end{tabular} & \begin{tabular}{|c|} 
Total Chloride \\
grams
\end{tabular} & $\begin{array}{l}\text { Total Flow } \\
\text { liters }\end{array}$ & $\begin{array}{l}\text { Total Flow } \\
\text { gallons }\end{array}$ \\
\hline Backwash Cycle & 2 & 8 & 2 & 10 & LX167-OPTC-BW-4 & 35 & 6.0 & 56 & 68 & & & & \\
\hline (mislabled) & 6 & 4 & 6 & & LX167-OPTC-BW-8 & & & 49 & 59 & & & 60.0 & 15.8 \\
\hline Brine Draw & 5 & 55 & 15 & 60 & LX167-OPTC-BDSR-55 & & & 58 & 73 & & & & \\
\hline \multirow[t]{11}{*}{ / Slow Rinse } & 10 & 50 & 20 & & LX167-OPTC-BDSR-50 & 38 & 2.85 & 60 & 75 & & & 28.5 & 7.53 \\
\hline & 15 & 45 & 25 & & LX167-OPTC-BDSR-45 & 38 & 3.00 & 265 & 355 & 3.14 & 2.38 & & \\
\hline & 20 & 40 & 30 & & LX167-OPTC-BDSR-40 & & & 2740 & 2060 & 17.66 & 21.97 & & \\
\hline & 25 & 35 & 35 & & LX167-OPTC-BDSR-35 & & & 21900 & 11600 & 66.59 & 120.12 & & \\
\hline & 30 & 30 & 40 & & LX167-OPTC-BDSR-30 & & & 38100 & 16700 & 137.96 & 292.50 & & \\
\hline & 35 & 25 & 45 & & LX167-OPTC-BDSR-25 & & & 47000 & 16300 & 160.88 & 414.86 & 103.1 & 27.2 \\
\hline & 40 & 20 & 50 & & LX167-OPTC-BDSR-20 & & 1.95 & 49100 & 14600 & 150.64 & 468.49 & & \\
\hline & 45 & 15 & 55 & & LX167-OPTC-BDSR-15 & & & 53100 & 13800 & 138.45 & 498.23 & & \\
\hline & 50 & 10 & 60 & & LX167-OPTC-BDSR-10 & & 1.95 & 53600 & 12100 & 126.26 & 520.16 & & \\
\hline & 55 & 5 & 65 & & LX167-OPTC-BDSR-5 & & & 55700 & 10800 & 111.64 & 532.84 & & \\
\hline & 60 & 0 & 70 & & LX167-OPTC-BDSR-0 & & & 56500 & 9580 & 99.35 & 546.98 & 39.0 & 10.3 \\
\hline \multirow[t]{2}{*}{ Rapid Rinse } & 2 & $\overline{4}$ & 72 & 6 & LX167-OPTC-RR-4 & 32 & 6.3 & 55300 & 7230 & 105.90 & 704.34 & & \\
\hline & 4 & 2 & 76 & & \begin{tabular}{|l|} 
LX167-OPTC-RR-2 \\
\end{tabular} & & & 41700 & 4760 & 151.07 & 1222.20 & 37.8 & 10.0 \\
\hline \multirow[t]{5}{*}{ Brine Tank Fill } & 8 & 7 & 84 & 15 & LX167-OPTC-BTF-10 & 35 & & 859 & 54 & & & & \\
\hline & 14 & 1 & 98 & & LX167-OPTC-BTF-20 & & & 342 & 57 & & & & \\
\hline & & & & & & & \multirow{2}{*}{\multicolumn{2}{|c|}{ kgram nitrate }} & Sum & 1.27 & 5.345 & kg Salt & 70.9 \\
\hline & & & Chloride & Nitrate & Drum Volume & Drum Vol & & & & & $11.78 \mathrm{I}$ & lb salt & \\
\hline & & & $(\mathrm{mg} / \mathrm{L})$ & $(\mathrm{mg} / \mathrm{l})$ & (liters) & (liters) & & & & & & & \\
\hline \multirow{9}{*}{$\begin{array}{l}\text { Drum \#1 Sample } \\
\text { Drum \#2 Sample }\end{array}$} & LX167-OPTC-DRUI & & 18600 & 5620 & 208.24 & 208.24 & 1.17 & & & & & & \\
\hline & LX167-OPTC-DRUI & & 24600 & 3390 & 69.41 & 69.41 & 0.24 & & & & & & \\
\hline & & & & & & Total: & 1.41 & & & & & & \\
\hline & & & & & & & & & \multicolumn{3}{|l|}{ Summary } & & \\
\hline & & & & & & & & & & & & & \\
\hline & & & & & & & & & \multirow{4}{*}{\multicolumn{2}{|c|}{$\begin{array}{l}\text { Gallons waste produced: } \\
\text { kg Nitrate removed: } \\
\text { Regen removal efficiency: } \\
\text { Gallons waste produced } \\
\text { w/ modifications suggested } \\
\text { Reduction in waste \% }\end{array}$}} & $\begin{array}{c}70.89 \\
1.27\end{array}$ & & \\
\hline & & & & & & & & & & & $95.2 \%$ & & \\
\hline & & & & & & & & & & & & & \\
\hline & & & & & & & & & & & $\begin{array}{c}47.5 \\
33.0 \%\end{array}$ & & \\
\hline
\end{tabular}




\section{Trial C - Regeneration Chart}

BC labs data, using solar salt

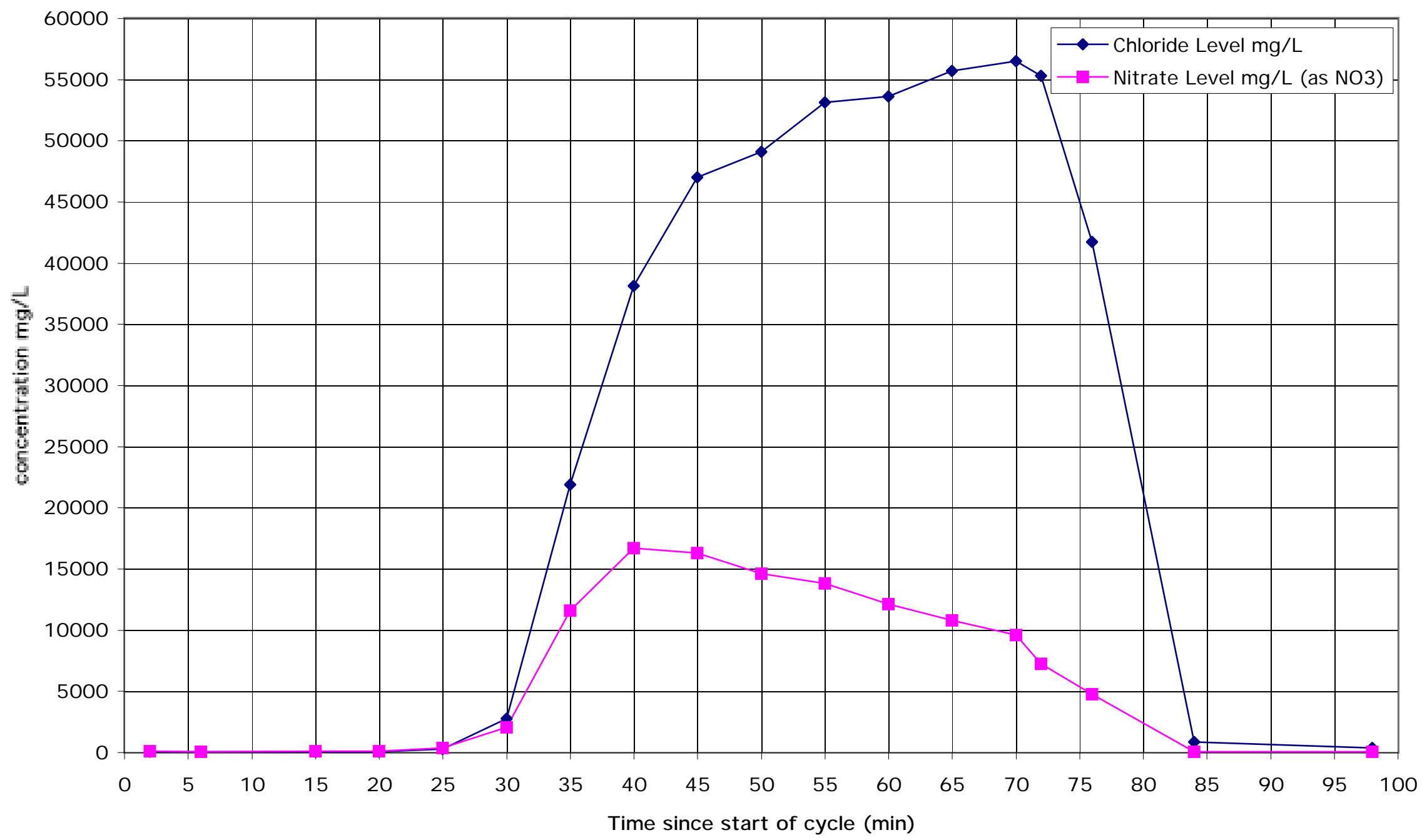




\section{0 ppm Scenario Predictions}





\section{0 ppm - Breakthrough Predictions}

based on Sybron Literature predictions, see Appendix F For sample calcs Single Column Mode

\begin{tabular}{|l|c|c|c|}
\hline \multicolumn{1}{|c|}{ Other } & ppm* & Conversion & ppm, CaCO3 \\
\hline \multicolumn{1}{|c|}{ Contaminants } & & Factor & \\
\hline Bicarbonate, $\mathrm{HCO3}$ & 370 & 0.82 & 303.4 \\
\hline Sulfate, SO4 & 70 & 1.04 & 72.8 \\
\hline Chloride, Cl & 79 & 1.41 & 111.39 \\
\hline
\end{tabular}

* Taken from Genmin analysis run on 12/18/98 (TF-834-EFLU-B111-1300), A2478

\begin{tabular}{|c|c|l|c|l|}
\hline Trial \# & Nitrate Conc & Conversion & $\mathrm{ppm}, \mathrm{CaCO} 3$ & grains/gal \\
\hline & (as NO3) ppm & Factor & & (as CaCO3) \\
\hline Scenario & 90.00 & 0.81 & 72.90 & 4.26 \\
\hline
\end{tabular}

Step 1 - Percent Nitrate

Percent Nitrate $=(\mathrm{NO} 3 \mathrm{ppm}$ as $\mathrm{CaCO} 3) /(\mathrm{NO} 3 \mathrm{ppm}$ as $\mathrm{CaCO} 3+\mathrm{SO} 4 \mathrm{ppm}$ as $\mathrm{CaCO} 3)$
$\% \mathrm{NO3}=$
0.50

Step 2 - Nitrate Leakage

Read from Figure \#3 in Sybron literature (pg 3)

Salt regeneration level ( $\mathrm{lb}$ salt/ $\mathrm{ft} 3$ resin):

Nitrate Leakage as \% of Influent Nitrate Level $\quad 27 \%$

Nitrate Leakage (ppm as NO3): $\quad 30.00$

Step 3 - Base Nitrate Capacity

Read from Figure \#4

Base Capacity (grains/ Ft3 (NO3 as CaCO3)) 6000

Step 4 - Predicted Run Length

Actual Run Length $=($ Throughput $) /(100 \%$-\%leakage $) / 100$

Throughput $=($ Base Nitrate Capacity $) /($ Influent Load) $\quad$ Based on flow to one column

Predicted Run Length $($ gal $/ \mathrm{ft} 3)=\quad 1,930$

Predicted Run Length (gal) 4,825

Predicted Run Length (liter) 18,268

\section{Compensation from Actual Data}

Actual gallons until breakthrough $\quad 5884$

Actual gallons before breakthrough $\quad 3707$

Actual leakage rate 

APPENDIX C

Hach Kit Data 



\section{Hach Test Kit Data}

These tests were done with a Hach DR/890 Colorimeter test kit. High range nitrate Accuvac ampules were used. The minimum detection limit (MDL) is reported to be $2.2 \mathrm{mg} / \mathrm{L}$ as $\mathrm{NO}_{3}{ }^{-}$. The maximum detection limit is reported to be $132 \mathrm{mg} / \mathrm{L}$ as $\mathrm{NO}_{3}^{-}$.

\section{Summary of Method*}

Cadmium metal reduces nitrates present in the sample to nitrite. The nitrite ion reacts in an acidic medium with sulfanilic acid to form an intermediate diazonium salt which couples to gentisic acid to form an amber-colored product.

\section{Interferences*}

\begin{tabular}{|l|l|}
\hline \multicolumn{1}{|c|}{ Interfering Substances } & \multicolumn{1}{|c|}{ Interference Levels and Treatment } \\
\hline Chloride & $\begin{array}{l}\text { Chloride concentrations above } 100 \mathrm{mg} / \mathrm{L} \text { will cause Low } \\
\text { results. }\end{array}$ \\
\hline Ferric Iron & All levels \\
\hline Nitrite & All Levels \\
\hline $\mathrm{pH}$ & $\begin{array}{l}\text { Highly buffered samples or extreme sample pH may exceed } \\
\text { the buffering capacity of the reagents and require sample } \\
\text { pretreatment. }\end{array}$ \\
\hline $\begin{array}{l}\text { Strong oxidizing and } \\
\text { reducing substances }\end{array}$ & Interfere at all levels. \\
\hline
\end{tabular}

\section{Tests Conducted}

- Accuracy check against nitrate standards prepared with DI water.

- Comparison of BC labs data and Hach Kit samples (actual data from Ion Exchange Optimization Tests, Trial B)

- Comparison of Hach kit results over various dilutions of B834 water with DI water

\section{Conclusions}

Hach kit data is accurate when using DI water. There are appears to be a significant amount of interferences present in the water collected at B834. Hach kit results are, on the average, $45 \%$ below what $\mathrm{BC}$ labs report. $\mathrm{BC}$ labs use ion chromotography to collect their nitrate data.

*Summarized from the DR/890 Colorimeter Procedures Manual 


\section{Hach Kit Test Trials - Accuracy check with DI Water}

Standards made using DI water, NaNO3.

Accuvac Ampule method used

Results reported in $\mathrm{mg} / \mathrm{L}$ as NO3

\begin{tabular}{|c|c|c|}
\hline Predicted & Chanda & Stephany \\
\hline 125 & 133.2 & 131.7 \\
\hline 100 & 103.5 & 99.3 \\
\hline 75 & 76.4 & 75.4 \\
\hline 50 & 49.9 & 66.6 \\
\hline 50 & 46.4 & 47.8 \\
\hline 25 & 27.5 & 26.3 \\
\hline 4.4 & 5.4 & 6.2 \\
\hline 2.2 & 1 & 2.4 \\
\hline
\end{tabular}


Hach Kit Accuracy Check

DI Water \& NaN03 standard solution

Accuvac ampule method

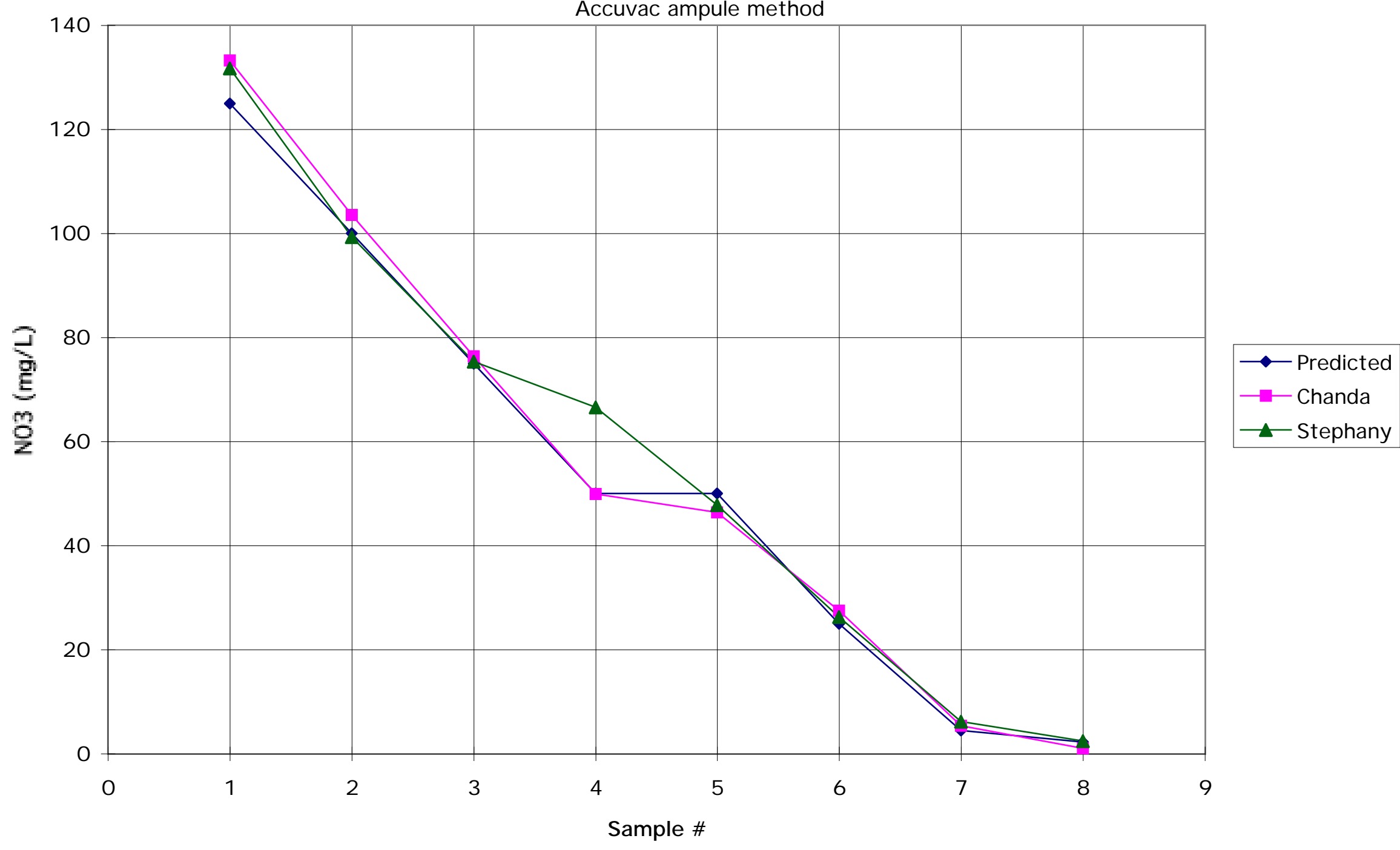


Hach Kit Test Trial - Data from Ion Exchange Optimization Study, Trial B All data in $\mathrm{mg} / \mathrm{L}$ as $\mathrm{NO}$

\begin{tabular}{|c|c|c|c|}
\hline Sample \# & BC & Hach & \% Difference \\
\hline 1 & 16 & 19.6 & $18.37 \%$ \\
\hline 2 & 18 & 12.5 & $-44.00 \%$ \\
\hline 3 & 51 & 51.3 & $0.58 \%$ \\
\hline 4 & 74 & 49.5 & $-49.49 \%$ \\
\hline 5 & 77 & 48.5 & $-58.76 \%$ \\
\hline 6 & 77 & 53.4 & $-44.19 \%$ \\
\hline 7 & 80 & 51.1 & $-56.56 \%$ \\
\hline 8 & 84 & 48.3 & $-73.91 \%$ \\
\hline 9 & 97 & 57.7 & $-68.11 \%$ \\
\hline 10 & 102 & 75.8 & $-34.56 \%$ \\
\hline 11 & 105 & 61.4 & $-71.01 \%$ \\
\hline 12 & 119 & 77.7 & $-53.15 \%$ \\
\hline & & Average: & $-44.57 \%$ \\
\hline
\end{tabular}


Hach Kit Accuracy Check

Data from IX Opt studies, Trial B

Accuvac ampule method

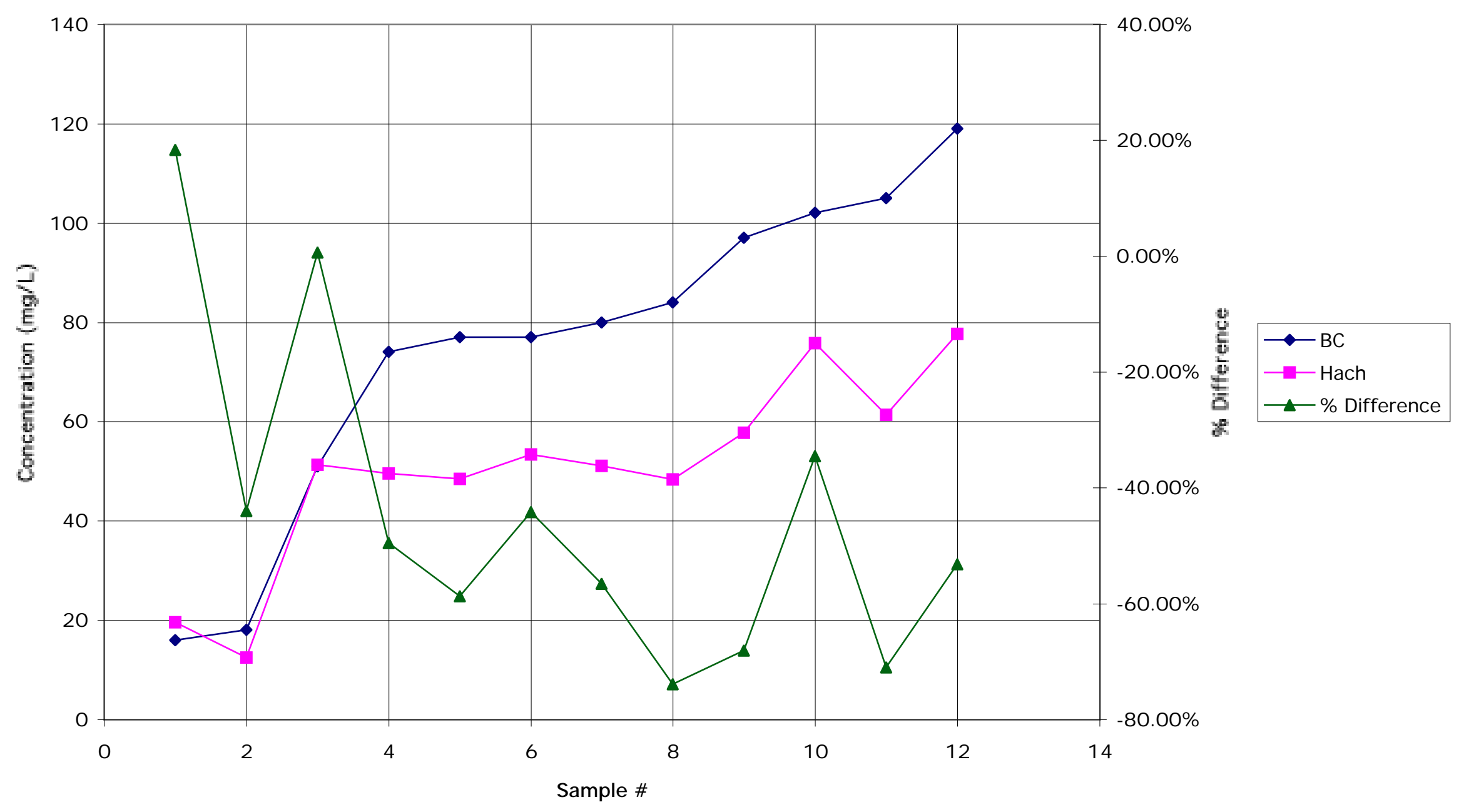




\section{Hach Test Kit Trials - Different percentages of B834 water}

\section{Test Procedure}

Take 3 liters B834 water, run through 3 inches ion exchange resin. Test water for initial concentration of nitrates

Initial Concentration:

Chanda: 0.8 Steph: $0.8 \quad \mathrm{mg} / \mathrm{L} \mathrm{NO3}$

\begin{tabular}{ccccc} 
Desired Conc & \multicolumn{2}{c}{ Volume start Add mg } & Add mg & \multicolumn{2}{c}{ Extract } \\
$\mathrm{mg} / \mathrm{L} \mathrm{NO3}$ & soln $(\mathrm{ml})$ & $\mathrm{NO3}$ & $\mathrm{NaNO3}$ & $\mathrm{ml}$ \\
125 & 1000 & 125 & 171.37 & 100
\end{tabular}

\begin{tabular}{|c|c|c|c|c|c|c|}
\hline Desired Conc & Volume start & Conc start sol & mg NO3 & Total Volume & Add $\mathrm{ml}$ & Extract \\
\hline mg/ L NO3 & soln $(\mathrm{ml})$ & $\mathrm{mg} / \mathrm{I}$ & have & final solution & DI water & (set aside) \\
\hline 100 & 250 & 125 & 31.25 & 313 & 63 & 100 \\
\hline 50 & 213 & 100 & 21.30 & 426 & 213 & 242 \\
\hline 25 & 184 & 50 & 9.20 & 368 & 184 & 192 \\
\hline 10 & 176 & 25 & 4.40 & 440 & 264 & 410 \\
\hline 5.0 & 30 & 10 & 0.30 & 60 & 30 & 60 \\
\hline
\end{tabular}

\section{Collected Data}

$\begin{array}{ccccccc}\text { \% of B834 Water } & \text { Expected } & \text { Chanda } & \text { Stephany } & \text { Average } & \text { Difference } & \% \text { Error } \\ 100 \% & 125 & 71.7 & 73.1 & 72.4 & 52.6 & 42 \% \\ 80 \% & 100 & 66.4 & 71.8 & 69.1 & 30.9 & 31 \% \\ 40 \% & 50 & 40.7 & 42 & 41.35 & 8.65 & 17 \% \\ 20 \% & 25 & 23.4 & 25 & 24.2 & 0.8 & 3 \% \\ 8 \% & 10 & 10.9 & 10.4 & 10.65 & -0.65 & -7 \%\end{array}$


Hach Kit Accuracy Check

Concentration verses \% of B834 water

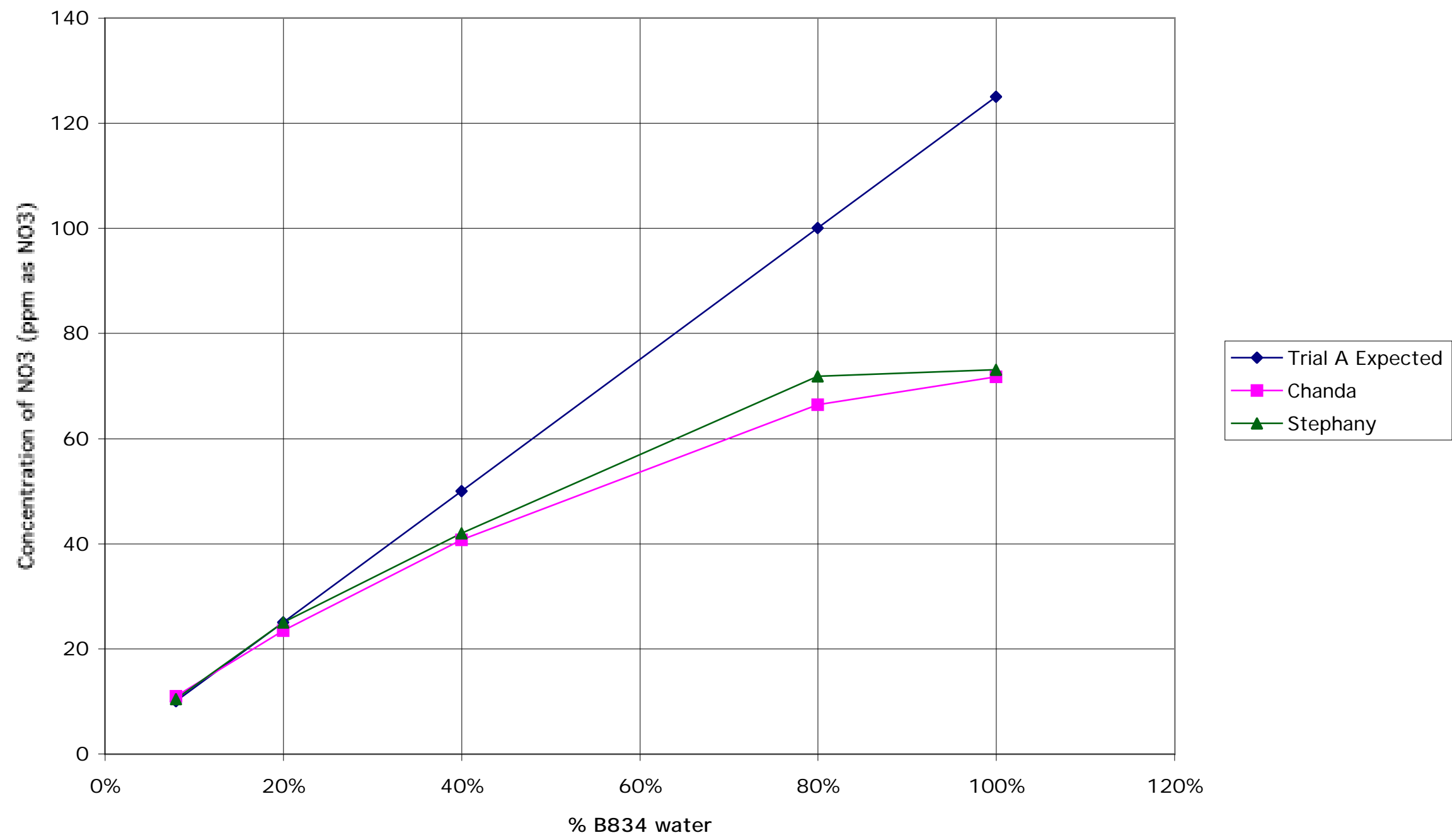



APPENDIX D

Perchlorate Tests \& Predictions 



\title{
Removal of perchlorate with nitrate saturated Sybron SR-7 ion exchange resin
}

\section{X-046}

\author{
Stephany Burge \\ Experiment performed from $3 / 11 / 99$ to $3 / 15 / 99$ \\ Analysis performed on $4 / 16 / 99$
}

\subsection{Summary}

The purpose of this experiment was to determine whether or not perchlorate would be removed from groundwater with a nitrate saturated ion exchange resin. A quantity of Sybron SR-7 resin was placed in a jar of de-ionized (DI) water with a nitrate concentration of $300 \mathrm{mg} / \mathrm{L}$ (as $\mathrm{NO}_{3}$ ). The resin and nitrate water were shaken for 24 hours. The resin was removed. A solution of DI water, with a $100 \mathrm{mg} / \mathrm{L}$ nitrate and $130 \mu \mathrm{g} / \mathrm{L}$ perchlorate, was prepared. The resin was placed in that solution and shaken for 24 hours. Perchlorate levels in the solution were analyzed before and after exposure to the resin. The before concentration was $130 \mu \mathrm{g} / \mathrm{L}$. The after concentration of perchlorate non-detectable. In conclusion, a nitrate saturated Sybron SR-7 will still preferentially remove perchlorates.

This is also suggested in the paper "Application of Ion-Exchange Technology for Perchlorate Removal from San Gabriel Basin Groundwater" by Montgomery Watson. The goal of their study was to determine a resin suitable for removing perchlorate via ion exchange. They tested two polystyrene based resins (similar to the SR-7 resin) and one polyacrylic resin. During testing, nitrate always broke through long before perchlorate for all of the resins. Perchlorate was also very difficult to remove from both of the polystyrene resins during regeneration.

\subsection{Methods}

This method will be repeated twice. Trial A and Trial B will be analyzed concurrently.

Step HI-Calculation of desired solutions

\begin{tabular}{|l|l|l|l|l|}
\hline & Quantity & Concentration* & meq/L & meq Total \\
\hline Sybron SR-7 Resin & $\begin{array}{l}0.5 \text { grams per } \\
\text { trial }\end{array}$ & $2.2 \mathrm{meq} / \mathrm{gram}$ & & $1.1 \mathrm{meq}$ \\
\hline Nitrate $\left(\mathrm{NO}_{3}\right)$ Starting Solution & 0.5 Liters & $300 \mathrm{mg} / \mathrm{L}$ & 300 & $150 \mathrm{meq}$ \\
\hline
\end{tabular}




\begin{tabular}{|l|l|l|l|l|}
\hline (Solution A) & & & & \\
\hline Nitrate in Solution B & 0.5 Liters & $100 \mathrm{mg} / \mathrm{L}$ & 100 & 50 meq \\
\hline Perchlorate $\left(\mathrm{ClO}_{4}\right)$ in Solution B & 0.5 Liters & $130 \mu \mathrm{g} / \mathrm{L}$ & 0.130 & $0.065 \mathrm{meq}$ \\
\hline
\end{tabular}

* The meq/L of perchlorate and nitrate is equal to the concentration in $\mathrm{mg} / \mathrm{L}$.

Step \#2 - Preparation of Solutions

The nitrate starting solution (Solution $\mathrm{A}$ ) was prepared by dissolving 0.412 grams of $\mathrm{NaNO}_{3}$ (or 300 grams of $\mathrm{NO}_{3}{ }^{-}$) in 1 liter of di-pnized water. The solution was mixed for several minutes.

The nitrate/perchlorate solution (Solution B) was prepared by dissolving nitrate and perchlorate in DI water. A starting solution of perchlorate in DI water was used. The starting concentration of that solution was thought to be $432 \mu \mathrm{g} / \mathrm{L}$. $230 \mathrm{ml}$ of the perchlorate starting solution was added to $970 \mathrm{ml}$ of DI water. The intent was to increase the perchlorate concentration in Solution B to $50 \mu \mathrm{g} / \mathrm{L}$. Unfortunately, the starting solution was much higher than expected. According to lab analysis, the final concentration of Solution B was $130 \mu \mathrm{g} / \mathrm{L} . \quad 0.274$ grams of $\mathrm{NaNO}_{3}$ (or 0.206 grams of $\mathrm{NO}_{3}$ ) were added. Using the Hach Colorimeter 890 test kit, the nitrate concentration was measured to be $105.4 \mathrm{mg} / \mathrm{L} \mathrm{NO}_{3}$.

Step \#2 Saturation of resin with Solution A.

Two $500 \mathrm{ml}$ jars were selected. 0.5 grams of resin were placed in each jar. $500 \mathrm{ml}$ of Solution A was placed in each jar. The jars were sealed and placed on a shaker for 24 hours. The resin was removed by filtering from Solution A.

\section{Step $\# 3$ Exposure to Solution B}

The $500 \mathrm{ml}$ jars were rinsed with DI water. The resin was placed back into the jars. 500 $\mathrm{ml}$ of Solution B was added to each jar. The jars were again placed on the shaker. They were allowed to continue shaking for 24 hours. The resin was again filtered out of the remaining solutions. Samples of Solution B before and after exposure to the resin were sent to CalTest labs for analysis.

\subsection{Results}

CalTest labs reported an initial concentration of perchlorates in Solution B to be 130 $\mathrm{ug} / \mathrm{L}$. For both trials, the concentration of the solution after exposure to perchlorate was non-detectable.

$$
\begin{aligned}
\text { Data logged m } & z B 148 \\
\text { of } & \operatorname{coc} \quad a_{23} 150
\end{aligned}
$$




\title{
Perchlorate removal with Sybron SR-7 ion exchange resin LX-168
}

\author{
Stephany Burge, Gene Kumamoto
}

Experiment performed on October 23, 1998

Analysis performed on November 9, 1998

Purpose:

A preliminary test was conducted to determine whether or not Sybron SR-7 resin will remove perchlorates from the ground water at Site 300 . Four liters of perchlorate spiked well water were poured through a test stand column filled with resin. Samples were collected from the influent and effluent streams. The samples will be analyzed for perchlorates levels.

Test Procedure:

$0.00158 \mathrm{~g}$ of potassium perchlorate were dissolved in 1 liter of DI water. $250 \mathrm{ml}$ were transferred into another flask. That water was added to 3.75 liters of water from well \#830-19 (Site 300). The estimated concentration of perchlorate is 50 ppb.

A test column at TFC was set up on the test stand. The column was filled with approximately 45.95 inches $^{3}$ of Sybron SR-7 resin. The resin was rinsed in DI water and allowed to settle.

A dip sample of the spiked perchlorate water was taken at 10:00 am. The perchlorate solution was slowly poured into the column. Effluent samples were taken when 2 and 3.5 liters of water had passed through the column (at 10:05 am and 10:15 am, respectively). The samples were sent to CLS for analysis.

Results:

According to lab analysis, the influent perchlorate concentration was $27 \mathrm{ppb}$. Both effluent concentrations were non-detectable. In conclusion, Sybron SR-7 resin will selectively remove perchlorates from groundwater.

$$
\text { Some water wa cued in Noell Semono testo }
$$

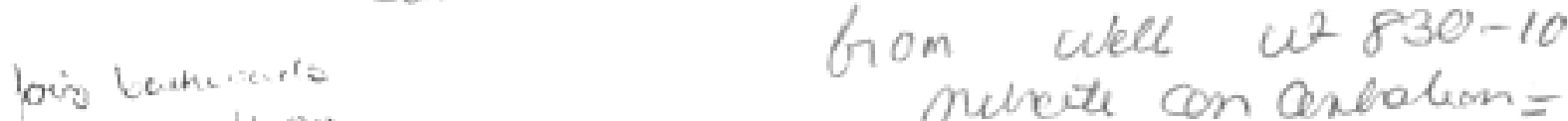

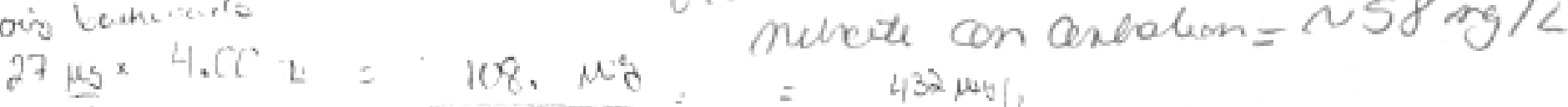

$$
\begin{aligned}
& .250 . \mathrm{C} \\
& =432 \mu \mathrm{t} / 2
\end{aligned}
$$

$$
\begin{aligned}
& \text { ingares Coes: }
\end{aligned}
$$

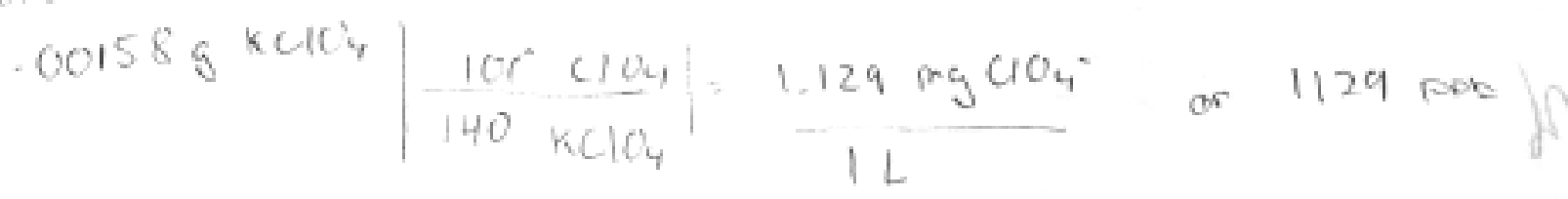

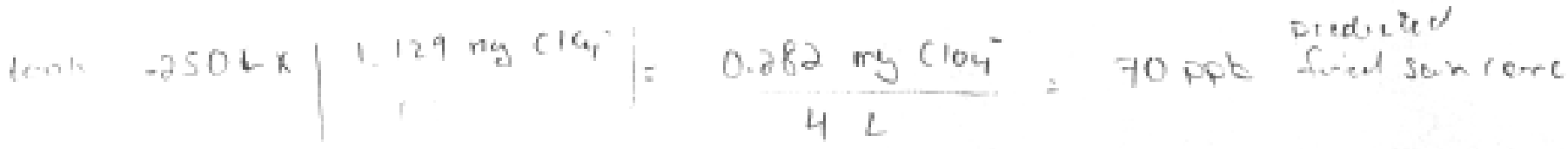


Subrion sucgastatiflow

$$
2.0 \rightarrow 5.0 \mathrm{gpm} / \mathrm{ft}^{3} \mathrm{resin}
$$

hove 46 enche resin $^{3}$ or $26.6 \times 10^{-3} \mathrm{ft}^{3}$ resin

$\max$ flow $\rightarrow .133 \mathrm{gpm}$

ninflow $\rightarrow .053 \mathrm{gpm}$

Flow of unit

15 punctios, 3.5 hitur $\rightarrow$.06/6 gallans monite

Wettle bet abour mumen flow! 16.2\%

alave min flow.

is $90 \mathrm{~d}$ 


\section{CLS Labs}

Analysis Report: Perchlorate, EPA Method 300.0

Analys is Code: E300.0

\section{C1ient: Lawrence Livermore Nat1. Lab University of California 7000 East Ave. /P.0. Box 808 Livermore, Ca $9455 i$}

Project: Perchlorate Removal

Date Sampled: $10 / 23 / 98$ Date Received: $10 / 23 / 98$ Date Extracted: N/A Date Analyzed: $10 / 26 / 98$

Date Reported: 11/05/98

Project No.: $\mathbf{A 2 3 9 9 4}$ Contact: ERD Data Management Team L-528

Phone: ( ) -

Lab Contact: George Hampton

Lab ID No.: P7716 Job No.: 817716 COC LOg NO.: GEA008 Batch No:: IC1981026

Instrument ID: IC101

Analyst ID: PONGC

Matrix: AQ

ANALYTICAL RESULTS

Lab / Client ID Analyte

Code

$1 A$ IX168-Effluent1 Perchlorate

2A IX168-Effluent2

Perchlorate

3A / IX168-inf

Perchlorate
6415

6415
THIS IS REALLY:
Results

(ug/L)
Rep. Limit

(ug/L)

$\begin{array}{ll}\text { ND } & 4.0 \\ \text { ND } & 4.0 \\ 27 & 4.0\end{array}$

1.0

$10 / 26 / 98$

$10 / 26 / 98$

$10 / 26 / 98$

ND - Not detected at or above indicated Reporting Limit 


\section{Perchlorate - Breakthrough Predictions}

based on Sybron Literature predictions, see Appendix F For sample calcs

\begin{tabular}{|l|c|c|c|}
\hline \multicolumn{1}{|c|}{ Other } & $\mathrm{ppm}^{*}$ & Conversion & $\mathrm{ppm}, \mathrm{CaCO} 3$ \\
\hline Contaminants & & Factor & \\
\hline Bicarbonate, $\mathrm{H}$ & 370 & 0.82 & 303.4 \\
\hline Sulfate, $\mathrm{SO} 4$ & 70 & 1.04 & 72.8 \\
\hline Chloride, $\mathrm{Cl}$ & 79 & 1.41 & 111.39 \\
\hline
\end{tabular}

* Taken from Genmin analysis run on 12/18/98 (TF-834-EFLU-B111-1300), A24778

\begin{tabular}{|c|c|c|c|c|}
\hline Trial \# & Perc Conc & Conversion & ppm, CaCO3 & grains/gal \\
\hline & (as NO3) ppm & Factor & & (as CaCO3) \\
\hline Any & 0.040 & 1.00 & 0.040 & 0.0023 \\
\hline
\end{tabular}

Step 1 - Percent Perchlorate

Percent Perchlorate $=($ Perc ppm as $\mathrm{CaCO} 3) /($ Perc ppm as $\mathrm{CaCO} 3+\mathrm{SO} 4 \mathrm{ppm}$ as $\mathrm{CaCO} 3)$

$\% \mathrm{NO}=\quad 0.055 \%$

Step 2 - Perchlorate Leakage

Figure \#3 in Sybron literature (pg 3)

Salt regeneration level ( $\mathrm{lb}$ salt/ft3 resin):

10

Perchlorate Leakage as \% of Influent Perc Level

Perchlorate Leakage ( $p p m$ as $\mathrm{ClO} 4$ ):

$45 \%$ ??? Could also be 0 ?

0.0180

Step 3 - Base Capacity

Read from Figure \#4

Base Capacity (grains/ft3 (Perc as CaCO3))

2000

Step 4 - Predicted Run Length

Actual Run Length $=($ Throughput $) /(100 \%-\%$ leakage $) / 100$

Throughput $=($ Base Capacity $) /($ Influent Load $)$

Predicted Run Length ( gal/ $\mathrm{ft}$ :

Predicted Run Length (gal)

Predicted Run Length ( litel

Including extra predictor factı

Breaking off at:

Years
$1,556,182$

$11,443,383$ Based on flow to 55 gallon drum

$43,313,205$ Based on flow to 55 gallon drum

$9,303,470$

$5,879,793$

3.20 at $3.5 \mathrm{gpm}$ flow rate 


\section{APPENDIX E}

Cost Analysis 



\section{Ion Exchange Cost breakdown Yearly basis, based on 1999 prices}

\section{Option 1: Nitrate only removal - Dual Column Mode}

Setup/ Installation

\section{Item}

Procure Equipment

1,000 gallon influent storage tank

$15 \mathrm{gpm}$ pump (1 to $2 \mathrm{hp}$ )

Motor starter, floating switch, controls

lon exchange unit

Regeneration waste storage tank, 500 gallon salt resistant tank

Mobilization to Site

Move ion exchange unit to actual site

Clean water flush

Controls and Interlocks

Senior technician

Technician

Total Setup/ Installation Costs

\section{Operations and Maintenance}

Control/Instrumentation Calib/Maintenance

$$
\text { Technician }
$$

\section{Mechanical O\&M}

Facility Operat

Consumables
Solar salt
Replaceme

Solar salt (50 lb bag/ 7,000 gallons treated water)

Replacement Sybron SR-7 Resin (ft3)

Electricity costs

Disposal of regeneration waste (cost per 55 gallon drum)

Facility Documentation and Data Collection

E300:00 Nitrate samples

Data management time

Nitrate Test kit

\section{Total Operations and Maintenance Costs (per year)}

Gallons treated per year (3.5gpm)

Kg nitrate removed per year (3.5 gpm)

Cost per gallon (overall)

Cost per gallon (yearly $0 \& M$ )

Cost per kg treated (overall)

cost per kg treated (yearly O\&M)
Quantity

1

\section{Cost per Unit}

1 tech, 1 day

1 tech, 3 days

1 week, LLNL 300

1 week, LLNL 500

1/2 day, month

500 hrs/year

124

2.5

3267
316

24

\section{$\$ 1,300$}

$\$ 600$

$\$ 3,000$

$\$ 10,000$

$\$ 800$

$\$ 60 / \mathrm{hr}$

$\$ 60 / \mathrm{hr}$

$\$ 82 / \mathrm{hr}$
$\$ 60 / \mathrm{hr}$

$\$ 25,572$

$\$ 60 / \mathrm{hr}$

$\$ 2,880$

Tota

$\$ 1,300$

$\$ 3,000$

10,000

$\$ 800$

$\$ 480$

$\$ 30,000$

$\$ 643$

$\$ 700$

$\$ 327$

$\$ 0.10 / \mathrm{kwh}$

$\$ 700$

$\$ 10 \quad \$ 240$

$\$ 37.50 /$ analysis

$\$ 1,200$

\section{otes}

Estimate from Ryan Process, Danville 8/13/99

Estimate from George Metzger $7 / 13 / 99$

Estimate from George Metzger 7/13/99

Based on cost of 15gpm Krudico unit already purchased

Estimate from Ryan Process, Danville 8/13/99

Technician rates from Dick Woodward 8/16/99

Includes informational sampling, $25 \%$ of their time

$\$ 5.17$ if buying 850 lbs plus from Culligan Water Supply

\$2

BC labs, $\$ 10$ for 20d TAT, once month for influent and effluent

Includes enough ampules for influent/ effluent sample every working day, $1 \mathrm{yr}$

$\$ 258,365$

$1,839,600$

44

$\$ 0.15$

$\$ 0.14$

$\$ 6,491$ 


\section{Option 2: Perchlorate removal}

\section{Setup/ Installation}

\section{Item}

Procure Equipment

55 gallon drum container

Resin (ft3)

Flow distributor

\section{Mobilization to Site}

Move ion exchange unit to actual site

Clean water flush

\section{Total Setup/ Installation Costs}

\section{Operations and Maintenance}

Control//Instrumentation Calib/Maintenance

$$
\text { Technical }
$$

\section{Mechanical O\&M}

Facility Operato

Replacement

Disposal of resin

Facility Documentation and Data Collection Perchlorate Samples

$$
\text { Data management time }
$$

\section{Total Operations and Maintenance Costs (per year)}

Gallons treated per year (3.5gpm)

Kg perchlorate removed per year

cost per gallon (overall)

cost per gallon (yearly $0 \& M$ )

Cost per kg perchlorate treated (overall)

\begin{tabular}{|c|c|c|}
\hline Quantity & Cost per Unit & Total \\
\hline 1 & $\$ 200$ & $\$ 200$ \\
\hline 7.4 & $\$ 280$ & $\$ 2,059$ \\
\hline 1 & $\$ 100$ & $\$ 100$ \\
\hline 1 tech, 1 day & $\$ 60 / \mathrm{hr}$ & $\$ 480$ \\
\hline 1 tech, 3 days & $\$ 60 / \mathrm{hr}$ & $\$ 1,440$ \\
\hline & & $\$ 4,279$ \\
\hline
\end{tabular}

Cost per kg perchlorate treated (O\&M)

\begin{tabular}{|c|c|c|c|}
\hline $1 \mathrm{hr}$ per week & $\$ 60 / \mathrm{hr}$ & $\$ 3,120$ & \\
\hline $500 \mathrm{hrs} /$ year & $\$ 60 / \mathrm{hr}$ & $\$ 30,000$ & $5 \%$ of their time \\
\hline 3.675 & $\$ 280$ & $\$ 1,029$ & Replace resin at max of every 3 years, calcs based on every two years \\
\hline 0.5 & $\$ 700$ & $\$ 350$ & \\
\hline 24 & $\$ 110$ & $\$ 2,640$ & \\
\hline 24 & $\$ 37.50 /$ analysis & $\$ 75$ & \\
\hline & & $\$ 37,214$ & \\
\hline & & & \\
\hline & & $1,839,600$ & \\
\hline & & 0.019 & \\
\hline & & $\$ 0.02$ & \\
\hline & & $\$ 0.02$ & \\
\hline & & $\$ 2,134,293$ & \\
\hline & & $\$ 1,914,207$ & \\
\hline
\end{tabular}




\section{Option 3: Nitrate and Perchlorate remova}

Setup/ Installation

\section{Item}

1,000 gallon influent storage tank

$15 \mathrm{gpm}$ pump (1 to $2 \mathrm{HP}$ )

Motor starter, floating switch, controls

lon exchange unit

Regeneration waste storage tank, 500 gallon salt resistant tank

Mobilization to Site

Move ion exchange unit to actual site $\quad 1$ tech, 1 day

Clean water flush

Controls and Interlocks

Senior technician

Technician

\section{Total Setup/ Installation Costs}

\section{Operations and Maintenance}

Control/Instrumentation Calib/Maintenance

\section{Technician \\ Mechanical O \& M}

Facility Operat

Solar salt (50 lb bag/ 7,000 gallons treated water)

Replacement Sybron SR-7 Resin

Electricity costs

Disposal of regeneration waste (cost per 55 gallon drum) Disposal of resin

Facility Documentation and Data Collection

E300:00 Nitrate samples

Perchlorate Samples

Data management time

Nitrate Test kit

Total Operations and Maintenance Costs (per year)

Gallons treated per year (3.5gpm)

Kg nitrate removed per year (3.5 gpm)

Cost per gallon (overall)

Cost per gallon (yearly O\&M)

Cost per kg nitrate treated (overall)

cost per $\mathrm{kg}$ nitrate treated (O\&M) tech, 3 days

$1 / 2$ day, month

\section{Cost per Unit}

$500 \mathrm{hrs} /$ year

$$
124
$$

24

$$
\begin{aligned}
& 24 \\
& 24 \\
& 48
\end{aligned}
$$

$\$ 60 / \mathrm{h}$

$\$ 2,880$

$\$ 1,300$

$\$ 600$

$\$ 3,000$

$\$ 800$

$\$ 60 / h$

$\$ 82 / \mathrm{hr}$

$\$ 60 / \mathrm{hr}$

$\$ 4,592$

$\$ 27,572$

\section{Total}

$\$ 1,300$

$\$ 3,000$

$\$ 12,000$

$\$ 800$

$\$ 480$

1,440

$\$ 30,000$

$\$ 643$

$\$ 1,400$

$\$ 327$

$\$ 221,475$

$\$ 0.10 / \mathrm{kwh}$

$\$ 700$

$\$ 700$

$\$ 10$

$\$ 110$

$\$ 37.50 /$ analysis

$\$ 1,200$

$\$ 240$

$\$ 2,640$

$\$ 1,800$
$\$ 262,105$

\section{Notes}

Estimate from Ryan Process, Danville 8/13/99

Estimate from George Metzger $7 / 13 / 99$

Estimate from George Metzger 7/13/99

Based on cost of $15 \mathrm{gpm}$ Krudico unit already purchased, includes 3rd resin tank for perchlorate removal Estimate from Ryan Process, Danville 8/13/99

Technician rates from Dick Woodward 8/16/99

\section{Includes informational sampling, $25 \%$ of their time}

$\$ 5.17$ if buying 850 lbs plus from Culligan Water Supply

$2.5 \mathrm{ft} 3 /$ column, replace perchlorate resin every year, every two years for nitrate resin

$\$ 700 /$ drum including adminstrative costs, Rob Tagesson 7/28/99

BC labs, $\$ 10$ for 20d TAT, say once month for influent and effluent

Cal Test, $\$ 110$ per sample

Includes enough ampules for influent/ effluent sample every working day, 1 yr 

APPENDIX F

Sample Calculations 



\section{Anion Exchange Resin for Superior Nitrate Removal}

IONAC SR-7 has three times the selectivity for nitrates of any commercially available anion exchange resin, which enables it to remove nitrates from sulfate-bearing waters without the danger of 'nitrate dumping.' Dumping occurs in other resins when the nitrate capacity is exhausted and sulfate ions push nitrate ions off the active sites. When this occurs, the effluent will contain more nitrate than the influent. At times, the finished water can exceed the U.S. Environmental Protection Agency's maximum contaminant level of $10 \mathrm{mg}$ nitrate as $\mathrm{N} / \mathrm{l}$.

IONAC SR-7 is ideal for small municipal systems and residential point-of-entry and point-of-use cartridges, because these have a tendency to be overrun and cause nitrates to be dumped. IONAC SR-7 has been specially prepared to meet drinking water standards and has passed taste and odor tests.

Typical

Characteristics

IONAC SR-7 uses a trialkyl quaternary amine exchange group on spherical beads of styrene-divinylbenzene copolymer.

It has the following typical characteristics:

Particle size distribution (U.S. Standard Wet) $-16 /+50$ Mesh

Effective Size 0.45 to $0.50 \mathrm{~mm}$

Total Weight Capacity $2.2 \mathrm{meq} / \mathrm{g}$

Total Volume Capacity $0.8 \mathrm{me} / \mathrm{ml}$

Water Retention 48 to $52 \%$

Whole Bead Count $>95 \%$

Average Hardness (Minimum) $500 \mathrm{~g} /$ bead

US FDA Extractable Test (ppm) with

Deioinized Water, Ethyl Alcohol, Acetic Acid All non-detectable

\section{Operating Conditions}

\begin{tabular}{|c|c|}
\hline Maximum operating temperature & $212^{\circ} \mathrm{F}\left(100^{\circ} \mathrm{C}\right)$ \\
\hline Minimum bed depth & 30 in $(76 \mathrm{~cm})$ \\
\hline Free board (rising space) & $100 \%$ \\
\hline Service flow rate & $2-5 \mathrm{gpm} / \mathrm{tt}^{3}(16-40 \mathrm{lhr} / \mathrm{l})$ \\
\hline Backwash expansion & $50 \%$ (minimum) \\
\hline Regenerant concentration & $\mathrm{NaCl} 5-12 \%$ \\
\hline Regenerant flow rate & $0.25-0.5 \mathrm{gpm} / \mathrm{ft}^{3}(2-4 / \mathrm{hr} / l)$ \\
\hline Regenerant injection time & $30-60$ minutes \\
\hline Displacement rinse volume & 1 bed volume (minimum) \\
\hline Displacement rinse flow rate & $0.25-0.5 \mathrm{gpm} / \mathrm{tt}^{3}(2-4 \mathrm{Lhr} / \mathrm{)})$ \\
\hline Fast rinse volume & 9 bed volumes (minimum) \\
\hline Rinse flow rate & Service flow rate \\
\hline
\end{tabular}




\section{SYBRON IONAC SR-7}

Advanced Anion Exchange Resin

Sample

Calculations
The following example illustrates the use of the curves on page 3 to calculate nitrate leakage, throughput capacity and actual run length in a conventional nitrate removal system.

\begin{tabular}{lccc} 
& $\mathbf{p p m}$ & $\begin{array}{c}\text { Conversion } \\
\text { Factor }\end{array}$ & $\mathbf{p p m , \mathbf { C a C O } _ { 3 }}$ \\
\hline Bicarbonate, $\mathrm{HCO}_{3}$ & 72.2 & 0.82 & 59.2 \\
Sulfate, $\mathrm{SO}_{4}$ & 115.1 & 1.04 & 119.7 \\
Nitrate, as N* & 14.4 & 3.57 & 51.4 \\
Choride, $\mathrm{Cl}$ & 36.3 & 1.41 & 51.2
\end{tabular}

Step 1 - Percent nitrate

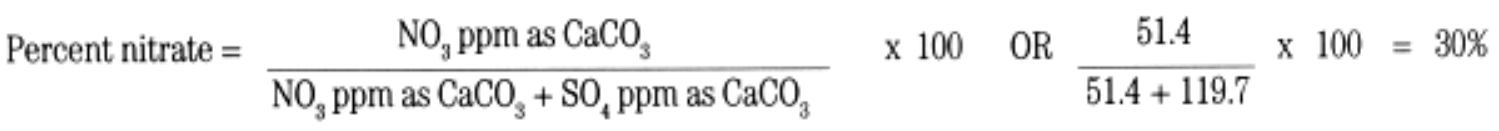

\section{- Nitrate leakage}

Determine nitrate leakage (Fig. 3) at 30\% nitrate and a regeneration level of $10 \mathrm{lbs}(100 \% \mathrm{NaCl})$ per cubic foot of SR-7. Leakage is $36 \%$ of the influent nitrate level, or $18.5 \mathrm{ppm}(\mathrm{mg} / \mathrm{l})$ nitrate at $\mathrm{CaCO}_{3}(5.17 \mathrm{ppm}$ nitrate as N).

\section{- Base nitrate capacity}

Determine base nitrate capacity (Fig.4) using the same parameters as in Step 2. Capacity is $4.2 \mathrm{Kgr}$ (4,200 grains) per cubic foot of resin.

\section{- Actual nun length ${ }^{\text {** }}$}

Actual run length $=\quad \frac{\text { Throughput }}{(100 \%-\% \text { leakage }) / 100}$

Throughput is found by dividing base nitrate capacity $\left(4,200 \mathrm{grains} / \mathrm{ft} \mathrm{t}^{3}\right)$ by influent load ( $3.0 \mathrm{grains} / \mathrm{gal}$.), or $1,400 \mathrm{gal} / \mathrm{ft}^{3}$. Using this value and leakage from Step 2, run length is $2,188 \mathrm{gal} / \mathrm{ft}^{3} \mathrm{resin}$. 


\section{Technical Data Series \\ SYBRON IONAC' SR-7}

Advanced Anion Exchange Resin

\section{Fig 1}

IONAC SR-7

Pressure Drop vs. Bed Depth

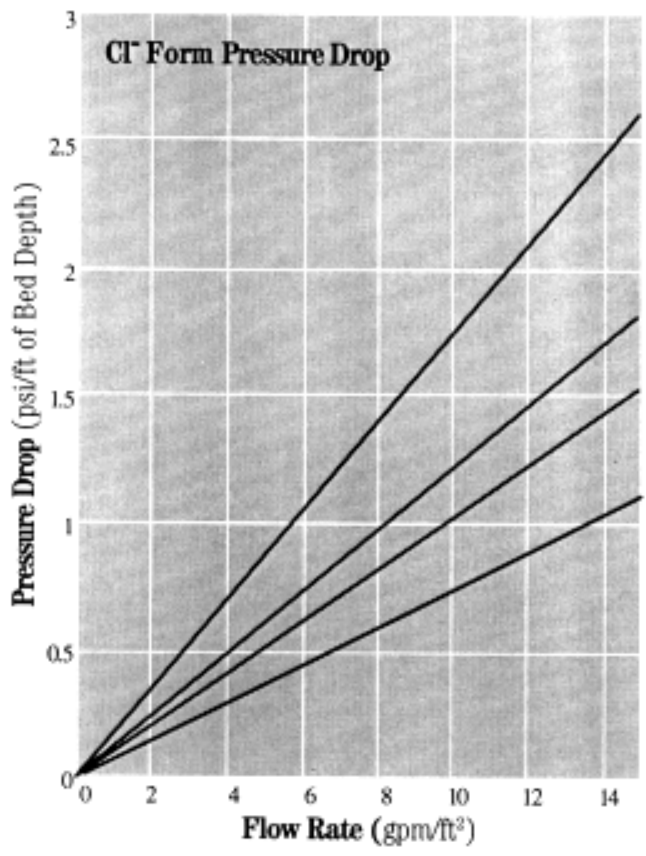

METRIC DONERSNON: $\mathrm{mWhr}=\mathrm{gpm} / \mathrm{Tt} \times 2.54$

IONAC SR-7

Nitrate Leakage vs. Regeneration Level

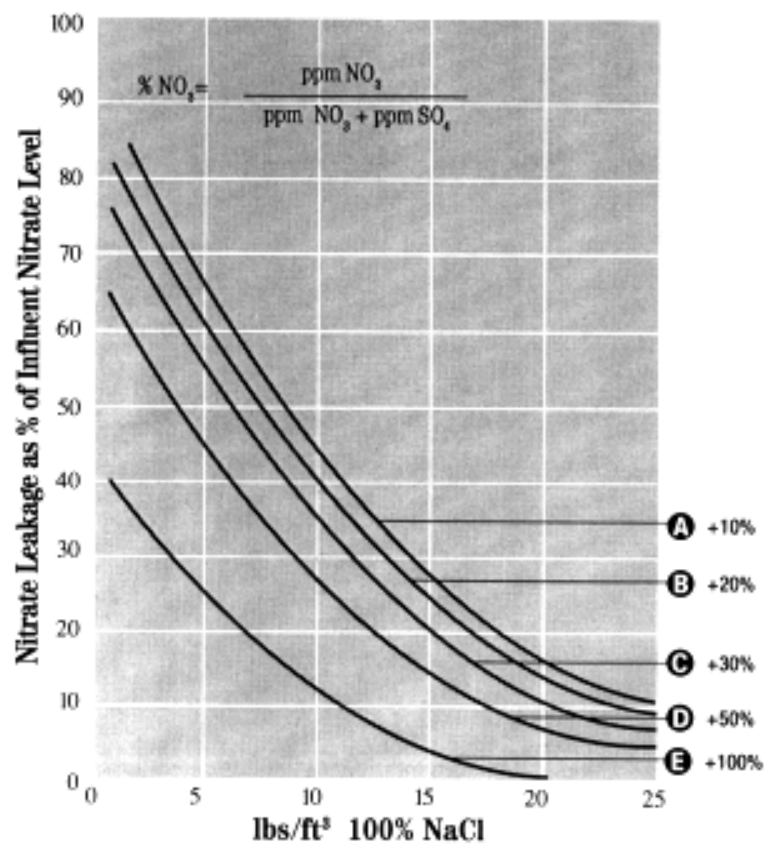

NETRIC COWERSION: $g /=\mid \mathrm{bs} / \mathrm{tt}^{3} \times 16$
Fig 2 IONAC SR-7

Backwash \& Bed Expansion

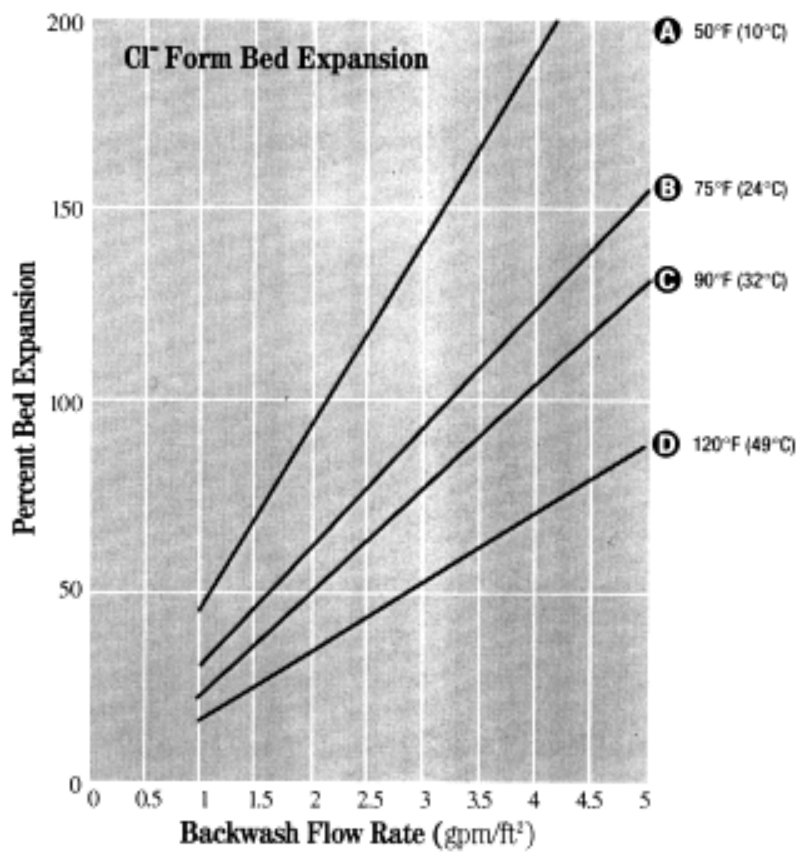

METRIC COWERSONE $\mathrm{m} / \mathrm{hr}=\mathrm{gpm} / \mathrm{Tt}^{2} \times 2.54$

\section{Fig 4 IONAC SR-7}

Nitrate Capacity vs. Regeneration Level

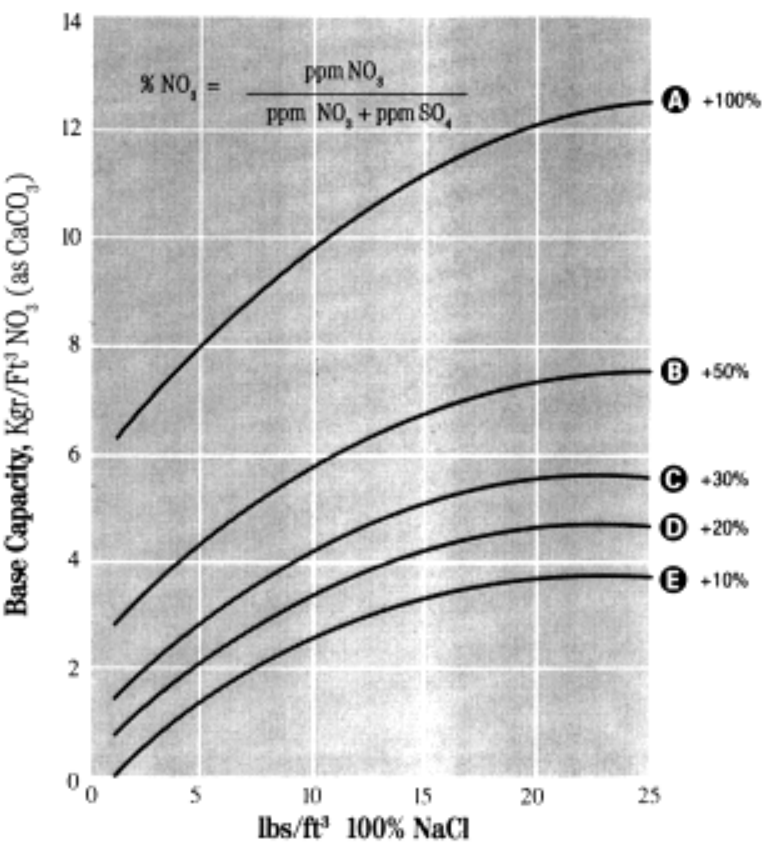

METRIC CONVERSION: $g|=| \mathrm{bS} / \mathrm{tt}^{3} \times 16$ 

APPENDIX G

Optimized

Regeneration Cycle Times 



\section{Optimized Regeneration Times}

\begin{tabular}{|l|c|c|}
\hline \multicolumn{1}{|c|}{ Cycle } & $\begin{array}{c}\text { Krudico's Settings } \\
(\mathbf{m i n})\end{array}$ & $\begin{array}{c}\text { Optimized Time } \\
(\mathbf{m i n})\end{array}$ \\
\hline Backwash & 10 & 10 \\
\hline Brine Draw/Slow Rinse & 56 & 60 \\
\hline Rapid Rinse & 6 & 6 \\
\hline Brine Tank Fill & 36 & 15 \\
\hline
\end{tabular}

